New Enaliarctos*

(Pinnipedimorpha) from the

Oligocene and Miocene of Oregon and the Role of "Enaliarctids" in Pinniped Phylogeny

\title{
ANNALISA BERTA
}




\title{
SERIES PUBLICATIONS OF THE SMITHSONIAN INSTITUTION
}

Emphasis upon publication as a means of "diffusing knowledge" was expressed by the first Secretary of the Smithsonian. In his formal plan for the Institution, Joseph Henry outlined a program that included the following statement: "It is proposed to publish a series of reports, giving an account of the new discoveries in science, and of the changes made from year to year in all branches of knowledge." This theme of basic research has been adhered to through the years by thousands of titles issued in series publications under the Smithsonian imprint, commencing with Smithsonian Contributions to Knowledge in 1848 and continuing with the following active series:

\author{
Smithsonian Contributions to Anthropology \\ Smithsonian Contributions to Astrophysics \\ Smithsonian Contributions to Botany \\ Smithsonian Contributions to the Earth Sciences \\ Smithsonian Contributions to the Marine Sciences \\ Smithsonian Contributions to Paleobiology \\ Smithsonian Contributions to Zoology \\ Smithsonian Folklife Studies \\ Smithsonian Studies in Air and Space \\ Smithsonian Studies in History and Technology
}

In these series, the Institution publishes small papers and full-scale monographs that report the research and collections of its various museums and bureaux or of professional colleagues in the world of science and scholarship. The publications are distributed by mailing lists to libraries, universities, and similar institutions throughout the world.

Papers or monographs submitted for series publication are received by the Smithsonian Institution Press, subject to its own review for format and style, only through departments of the various Smithsonian museums or bureaux, where the manuscripts are given substantive review. Press requirements for manuscript and art preparation are outlined on the inside back cover.

Robert McC. Adams Secretary

Smithsonian Institution 


\title{
New Enaliarctos* (Pinnipedimorpha) from the Oligocene and Miocene of Oregon and the Role of "Enaliarctids" in Pinniped Phylogeny
}

\author{
Annalisa Berta
}

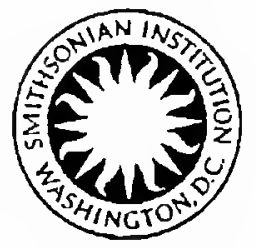

SMITHSONIAN INSTITUTION PRESS

Washington, D.C. 


\section{A B S T R A C T}

Berta, Annalisa. New Enaliarctos* (Pinnipedimorpha) from the Oligocene and Miocene of Oregon and the Role of "Enaliarctids" in Pinniped Phylogeny. Smithsonian Contributions to Paleobiology, number 69, 33 pages, 22 figures, 1991.-Three new species of the pinnipedimorph Enaliarctos* are described from the marine late Oligocene and early Miocene (Arikareean and Hemingfordian or early Barstovian correlatives) of coastal Oregon. Enaliarctos tedfordi, new species, is based on a partial cranium from the late Oligocene Yaquina Formation. A related new species, Enaliarctos emlongi, is founded on a nearly complete cranium, jaws, and associated skeletal elements from the late Oligocene to early Miocene Nye Mudstone. A third new species, Enaliarctos barnesi, is based on a partial cranium and jaws from late Oligocene or early Miocene rocks near the contact between the Yaquina Formation and the Nye Mudstone. Another skull, from the Nye Mudstone, is referred to a previously described species, Enaliarctos mitchelli Barnes, 1979. Three of these species, E. mitchelli, E. emlongi, and E. tedfordi form a monophyletic clade, united by reduced cheek teeth cingula and short metacone of the upper carnassial. The major trend observed in Enaliarctos over 10 million years of history is an intermediate stage in the transformation to homodonty evidenced by premolarization of the upper carnassial and molars and reduction and simplification of cusps on the lower carnassial.

Cladistic analysis of $52 \mathrm{cranial}$ and dental characters suggests the following phylogenetic hypotheses: (1) the subfamily "Enaliarctinae" (= "Enaliarctidae") is paraphyletic, (2) monophyly of the genus Enaliarctos* is questioned although the status of this taxon as sister taxon to other pinnipeds is affirmed, (3) other "enaliarctid" pinnipeds, Pteronarctos and Pinnarctidion, are assigned to less inclusive pinniped clades (Pteronarctos + all other pinnipeds and Pinnarctidion + Desmatophoca, Allodesmus, and the Phocidae).

OFFICIAL PUBLICATION DATE is handstamped in a limited number of initial copies and is recorded in the Institution's annual report, Smithsonian Year. SERIES COVER DESIGN: The trilobite Phacops rana Green.

Library of Congress Cataloging-in-Publication Data

Berta, Annalisa

New Enaliarctos* (Pinnipedimorpha) from the Oligocene and Miocene of Oregon and the role of "Enaliarctids" in Pinniped phylogeny / Annalisa Berta.

p. cm.-(Smithsonian contributions to paleobiology ; no. 69)

Includes bibliographical references.

1. Enaliarctos. 2. Paleontology-Oligocene. 3. Paleontology-Miocene 4. Paleontology-Oregon. I. Title. Il. Series.

QE701.S56 no.69 [Qe882.P5] $560 \mathrm{~s}-\mathrm{dc} 20$ [569'.74] $91-18125$

(2) The paper used in this publication meets the minimum requirements of the American National Standard for Permanence of Paper for Printed Library Materials Z39.48_-1984. 


\section{Contents}

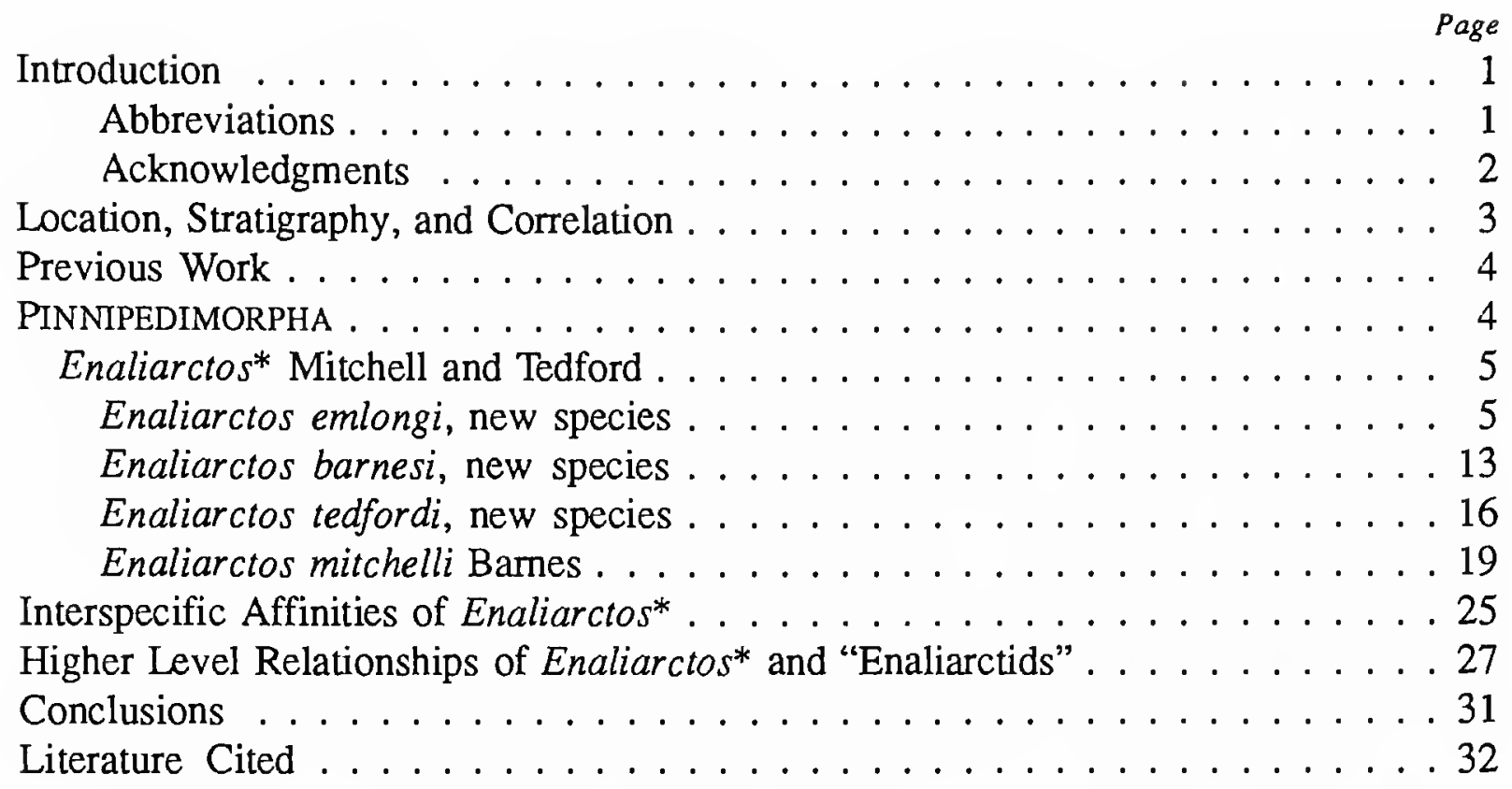





\title{
New Enaliarctos* \\ (Pinnipedimorpha) from the \\ Oligocene and Miocene of Oregon and the Role of "Enaliarctids" in Pinniped Phylogeny
}

\author{
Annalisa Berta
}

\section{Introduction}

"Enaliarctids" are basal pinnipeds implicated in the higher level phylogeny of all other pinnipeds (including otariids, odobenids, phocids, and their fossil allies). Initial study established "enaliarctids" as an intermediate evolutionary stage between ursoids and "otarioids" (including otariids, odobenids, and the extinct desmatophocids) (Mitchell and Tedford, 1973). This interpretation was part of a broader, diphyletic view of pinnipeds that proposed that "otarioids" derived from ursids whereas phocids originated from mustelids (Mivart, 1885; McLaren, 1960; Tedford, 1976). This notion was widely accepted (Repenning, 1976; Repenning and Tedford, 1977; Barnes, 1979; de Muizon, 1982; King, 1983). Recently, however, Wyss (1987) rejected the "Otarioidea" as based largely on primitive characters and he marshalled osteological, soft anatomical, and biomolecular evidence to support a monophyletic origin of pinnipeds. He concluded that "enaliarctids" as traditionally defined are paraphyletic and he recognized Enaliarctos as the sister group to the remaining pinnipeds. Pinniped monophyly was further strengthened by skeletal evidence provided by Wyss (1988a), Berta et al. (1989), and Berta and Ray (1990).

Recent reviews of carnivoran phylogeny demonstrate,

Annalisa Berta, Department of Biology, San Diego State University, San Diego, California, 92182 (Research Associate in the Department of Paleobiology, National Museum of Natural History, Smithsonian Institution).

Review Chairman: Clayton E. Ray, National Museum of Natural History, Smilhsonian Institution, Washington, D.C. 20560.

Reviewers: Lawerence G. Barnes, Natural History Museum of Los Angeles County, Los Angeles; and André R. Wyss, University of California, Santa Barbara. however, that there is no consensus regarding pinniped relationships. While expressing some reservations, Flynn et al. (1988) endorsed monophyly whereas Wozencraft (1989) rejected Wyss's arguments and concluded that pinnipeds are diphyletic. Barnes (1989) also contested Wyss's conclusions and supported recognition of the "Otariidae" (= "Otarioidea") comprised of the following subfamilies: Enaliarctinae, Otariinae, Desmatophocinae, Allodesminae, Imagotariinae, Dusignathinae, and Odobeninae. This latter arrangement follows that originally proposed by Mitchell $(1968,1975)$.

A large, diverse, well-preserved collection of fossil pinnipeds representing the genus Enaliarctos* found by Douglas Emlong from late Oligocene-early Miocene rocks of coastal Oregon formed the basis for this study. This report provides description of Enaliarctos* species new to the published record and an analysis of their interrelationships. Also considered is the role of "enaliarctids" in pinniped phylogeny.

This study suggests that Enaliarctos should be regarded as a metataxon, so indicated by an asterisk $\left({ }^{*}\right)$. This convention, an asterisk beside the taxonomic name (formulated by Gauthier, 1986; see also Gauthier et al., 1988; Donoghue, 1985) is used to designate taxa for which there is no unambiguous character evidence supporting either monophyly or paraphyly.

ABBREVIATIONS.- The following institutional abbreviations are used:

UCMP Museum of Paleontology, University of California, Berkeley, CA

USNM Collections of the former United States National Museum, now in the National Museum of Natural History, Smithsonian Institution, Washington, D.C. 


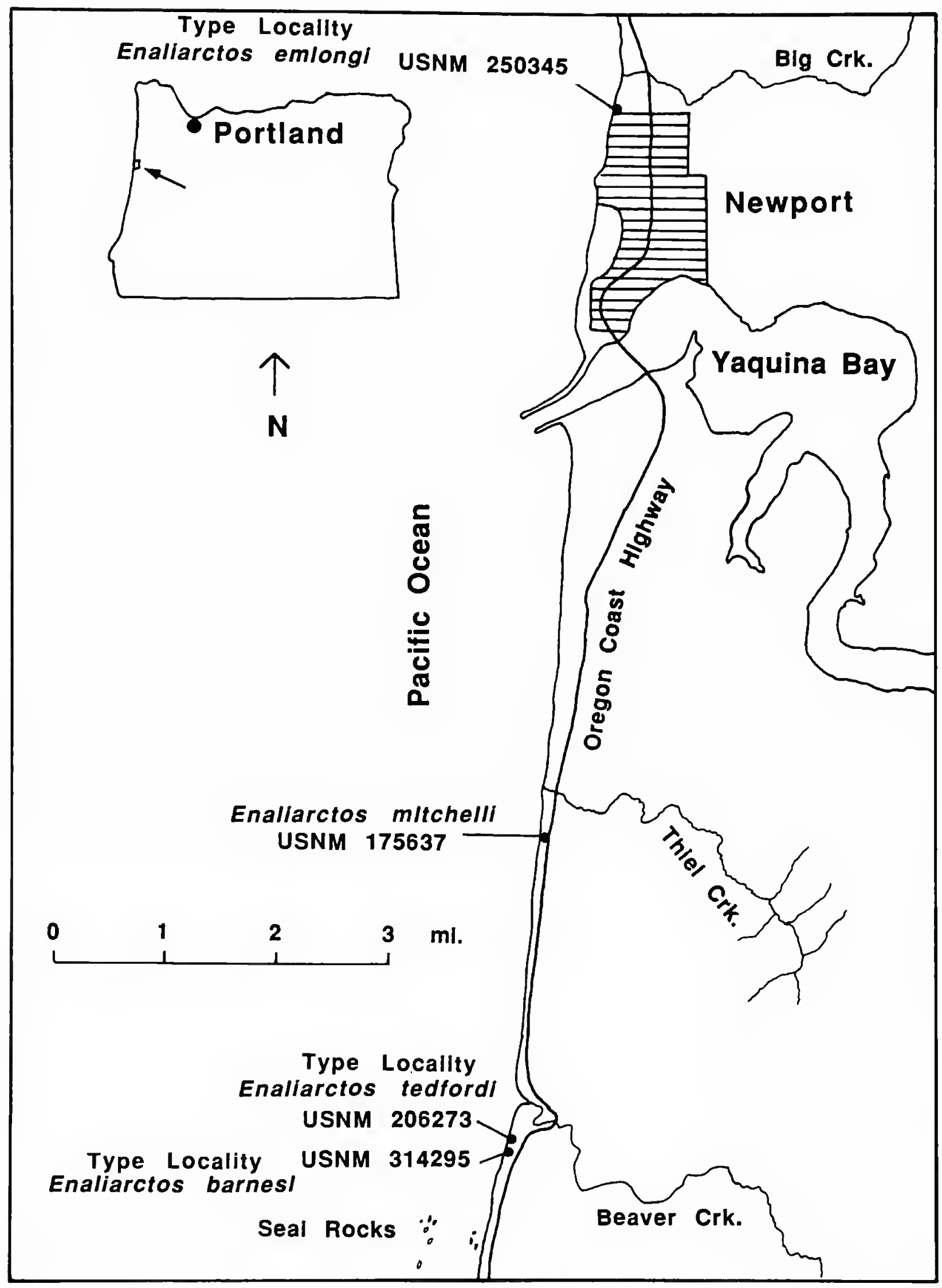

FIGURE 1.-Detail of part of the Yaquina 15-minute quadrangle, USGS, showing the localities discussed in the text. Arrow indicates location of map enlargement.

ACKNOWLEDGMENTS.-Specimens were skillfully prepared by Ed Pederson (American Museum of Natural History), Charles A. Repenning (U.S. Geological Survey, Denver), and Gladwyn Sullivan and Michael Tiffany (National Museum of Natural History). Line drawings were made by Christi Endres. Michael McCaffery and Nicki Watson (San Diego State University) greatly assisted with specimen photography. David Bohaska and Robert Purdy (National Museum of Natural
History) provided locality information and assistance with the measurement of specimens.

Lawrence G. Barnes (Natural History Museum of Los Angeles County) provided casts of comparative specimens. For permission to study specimens under their care I thank L.G. Barnes, Clayton E. Ray (National Museum of Natural History), and Richard $\mathrm{H}$. Tedford (American Museum of Natural History). 


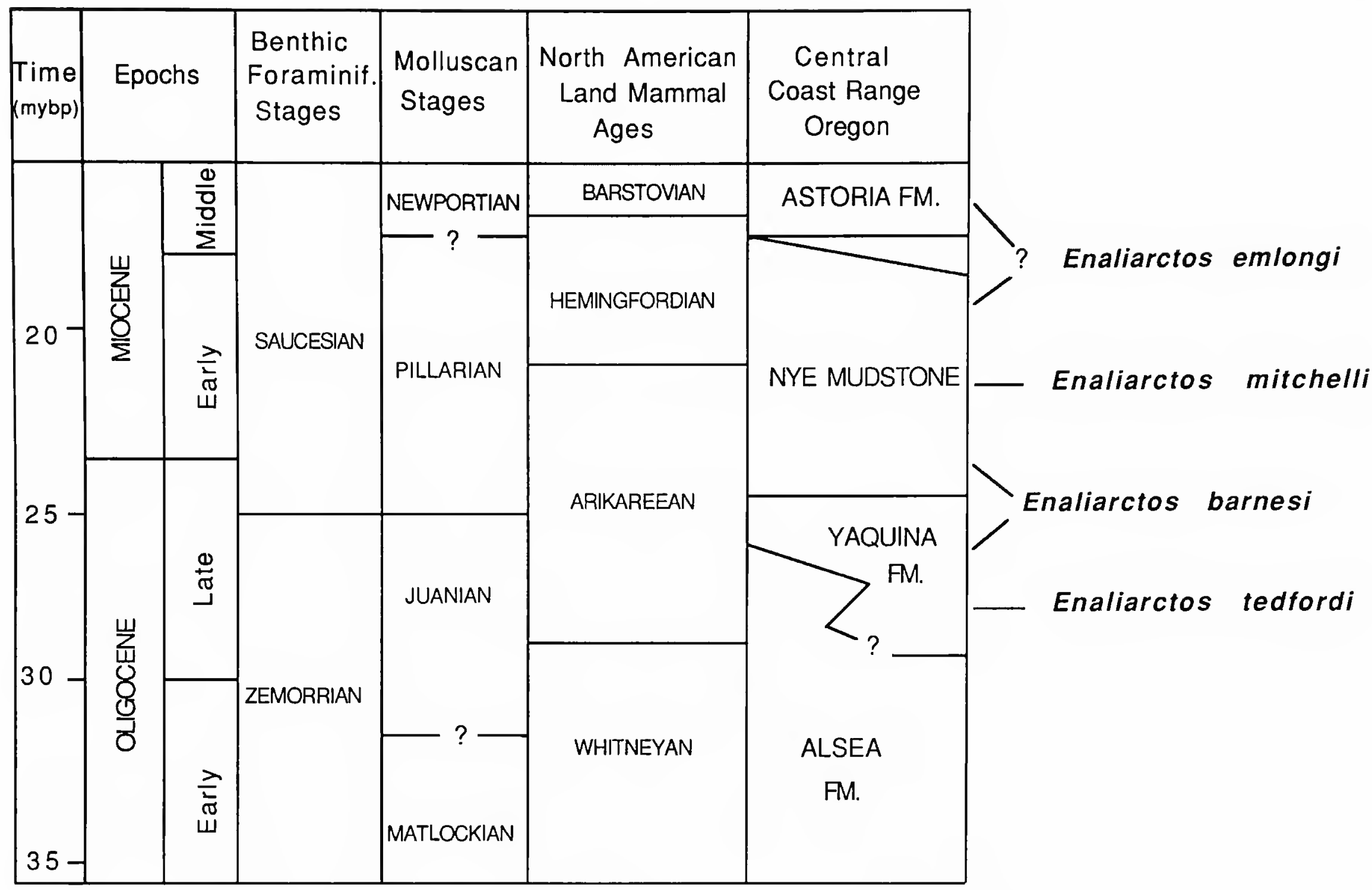

FIGURE 2.-Correlation of rock units containing Enaliarctos species (after Berggren et al., 1985 (time scale and correlation of NALMA) and Armentrout et al., 1983).

L.G. Barnes, R.H. Tedford, A.R. Wyss, C.E. Ray, and C.R. Crumly have provided valuable comments on the manuscript.

Emlong's field work was supported by the Smithsonian Institution through the Smithsonian Research Foundation and the Walcott and Kellogg Funds.

I gratefully acknowledge financial support for this research provided by NSF grant BSR 8607061.

\section{Location, Stratigraphy, and Correlation}

Marine sedimentary rocks crop out in structural basins along the Oregon coast at Astoria, Tillamook, Newport, and Coos Bay (Snavely et al., 1964). Fossil specimens referred to Enaliarctos* described in this report were collected by Douglas Emlong from rock units exposed in the Yaquina Bay area between Newport and Waldport in northwestern Lincoln County, Oregon (Figure 1). This region has been mapped (Snavely et al., 1976) and more detailed descriptions of the regional geology are given in Snavely et al., 1980. The fossils described below come from three successive formations of late Oligocene through early Miocene age.

The Yaquina Formation, composed of sandstone and siltstone of late Oligocene age, overlies siltstone of the Alsea Formation (Snavely et al., 1980). This formation has been assigned to the Juanian Molluscan Stage (Addicott, 1976; Armentrout, 1981) and Zemorrian Foraminiferal Stage (Armentrout et al., 1983, chart). The Yaquina Formation has produced, in addition to pinnipeds, desmostylians (Domning et al., 1986), cetaceans (Emlong, 1966; Barnes, 1987b), and a single land mammal, an anthracothere. The stage of evolution of the anthracothere (see Domning et al., 1986) suggests correlation of this formation with the early part of the Arikareean land mammal age, approximately 28-25 Ma (Figure 2).

Marine siltsone and fine-grained sandstone of the Nye Mudstone overlie by gradational contact the Yaquina Formation (Snavely et al., 1980). The Nye Mudstone is late Oligocene to early Miocene in age and has been assigned to the Pillarian Molluscan Stage (Addicott, 1976; Armentrout, 1981), which has been correlated with the Saucesian Foraminiferal Stage (Armentrout et al., 1983, chart). The Nye Mudstone can be correlated with the middle and late Arikareean and early Hemingfordian, approximately 25-18 Ma (Figure 2).

Sandstone and siltstone of the Astoria Formation un- 
conformably overlie the Nye Mudstone (Snavely et al., 1980). The holotype of Enaliarctos emlongi, according to Emlong's field notes, was collected "north of the Nye-Astoria contact in the Astoria Formation." Repenning (pers. comm.) has suggested that this specimen may actually be from the upper part of the Nye Mudstone. A sample of the enclosing matrix of USNM 250345, processed for foraminifera by Kristin MacDougall of the U.S. Geological Survey, Menlo Park, yielded taxa that were not age diagnostic. The Astoria Formation spans the late part of the early Miocene through the early part of the middle Miocene (Barnes, 1987a; Armentrout, 1981) and has been assigned to the Newportian Molluscan Stage (Addicott, 1976; Armentrout, 1981), which has been correlated with the Saucesian Foraminiferal Stage (Addicott, 1976; Armentrout et al., 1983, chart). Two other fossil pinnipeds have been recovered from the Astoria Formation. Desmatophoca oregonensis was collected from the Astoria Formation, at an unspecified horizon (Barnes, 1987a) and Pteronarctos goedertae was collected from a horizon just above the base of the Astoria Formation where it contacts the underlying Nye Mudstone (Barnes, 1989). A chalicothere collected from the Iron Mountain horizon within the Astoria Formation together with other biostratigraphic (molluscan and foraminiferal) and radiometric evidence provided a correlation of the Astoria Formation with the Hemingfordian or early part of the Barstovian between 19 and 15 Ma (Barnes, 1987a; Munthe and Coombs, 1979) (Figure 2).

\section{Previous Work}

Table 1 summarizes previous arrangements of "enaliarctids" discussed below. Mitchell and Tedford (1973) described a new genus and species of the pinnipedimorph, Enaliarctos mealsi, from early Miocene rocks within the Pyramid. Hill Sandstone Member of the Jewett Sand at Pyramid Hill, Kern County, California. They erected the new subfamily of the Otariidae, Enaliarctinae, to accommodate this taxon. As noted previously, Enaliarctos* was viewed as a transitional form, intermediate between terrestrial carnivores, especially ursoids, and the aquatic Otariidae. Tedford (1976) elevated the Enaliarctinae to familial level and placed the group in the superfamily Otarioidea.

Barnes (1979) described a second species of Enaliarctos ${ }^{*}, E$. mitchelli, and proposed a new genus and species, Pinnarctidion bishopi; both were collected from Pyramid Hill, California, from rocks at a stratigraphically higher level within the Pyramid Hill Sandstone Member than the deposits that produced E. mealsi. A third new genus and species of "enaliarctid" was recently described by Barnes (1989), Pteronarctos goedertae, from the late early Miocene Astoria Formation near Newport, Lincoln County, Oregon. In this same paper, Barnes reviewed the status of another taxon, Kamtschatarctos sinelnikovae, from the Miocene of the USSR proposed by Dubrovo $(1981,1984)$ as a new genus and species of "enaliarctid" for which she established a new subfamily, the
TABLE 1.-Previous classifications of "enaliarctids" and selected groups.

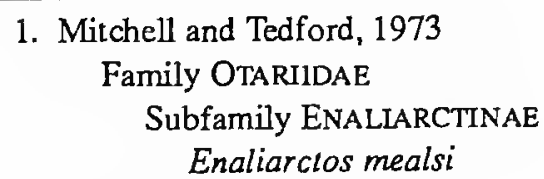

1. Mitchell and Tedford, 1973

Family OTARIIDAE

Subfamily ENALIARCTINAE

Enaliarctos mealsi

2. Tedford, 1976

Superfamily OTARIOIDEA

Family ENALIARCTIDAE

Enaliarclos mealsi

Family OTARIIDAE (including Odobeninac)

3. Barnes, 1979; 1989

Family OTARIIDAE

Subfamily ENALIARCTINAE

Enaliarctos mealsi, E. mitchelli

Pinnarctidion bishopi

Pteronarctos goedertae

Kamtschatarctinae. Barnes reassigned Kamtschatarctos to the Imagotariinae, which he recognized as a subfamily of the Otariidae. Thus, Barnes recognized the Enaliarctinae including Enaliarctos*, Pinnarctidion, and Pteronarctos as a basal group of otariid pinnipeds involved in the ancestry of various otariid lineages.

Although Wyss (1987) proposed no formal classification of pinnipeds, he regarded the "Enaliarctidae" as paraphyletic. Enaliarctos was recognized as the sister group of all other pinnipeds. Pinnarctidion and Allodesmus were regarded as members of a group including odobenids and phocids. My analysis agrees with the latter arrangement, and I provide evidence for recognition of Enaliarctos as a metataxon and Pteronarctos as the sister taxon of a clade that includes otariids, odobenids, desmatophocids, and phocids. Additional skeletal material referrable to Pteronarctos is presently under study (Berta, in prep.).

\section{PINNIPEDIMORPHA}

This taxon includes Enaliarctos*, Pteronarctos, Otariidae, Odobenidae, Allodesmus, Desmatophoca, Pinnarctidion, and Phocidae.

DEFINITION.-The most recent common ancestor of $E_{n}$ aliarctos and all of its descendants.

DIAGNOSIS.-Pinnipedimorphs are distinguished by the following synapomorphies: posterior extension of the palatine process of the maxilla; large infraorbital foramen; anterior palatine foramina positioned anterior to the maxillary-palatine suture; greatly reduced or absent lacrimal that does not contact the jugal; supraorbital processes absent or large and shelf-like; foramen rotundum merged with the anterior lacerate foramen; large epitympanic recess; postglenoid foramen vestigialabsent; jugular foramen greatly enlarged; enlarged auditory ossicles; pseudosylvian sulcus strongly developed; $\mathrm{M}^{1-2}$ small relative to premolars; $\mathrm{M}_{1}$ entoconid and hypoconid reducedabsent; $M_{3}$ absent; short, robust humerus with strongly developed deltopectoral crest and enlarged tuberosities; loss of 
entepicondylar foramen on humerus; elongation of digit I in the manus and digits I and V in the pes; short ilium; extemely short, anteroposteriorly flattened femur and medially inclined condyles; large, broadly developed greater trochanter on the femur; conical patella.

COMMENTS.-Berta et al. (1989) originally proposed the name Pinnipedimorpha to include Enaliarctos and all other pinnipeds and used postcranial synapomorphies (listed above) to diagnose this monophyletic group. Barnes' (1989) arrangement differs in his incorporation of Enaliarctos in a more exclusive group of pinnipeds (Otariidae sensu lato) in which the Phocidae were not included. Of the 19 characters used by Barnes to support the monophyly of the "Otariidae" most apply to more inclusive groups.

\section{Enaliarctos* Mitchell and Tedford}

TYPE SPECIES.-Enaliarctos mealsi Mitchell and Tedford, 1973.

INCLUDED SPECIES.-Enaliarctos mealsi Mitchell and Tedford, 1973, E. mitchelli Barnes, 1979, and three new species: $E$. tedfordi, E. emlongi, and E. barnesi.

DEFINITION.-Enaliarctos* is a metataxon composed of the common ancestor of Enaliarctos* and all the species listed above. Enaliarctos* possesses the diagnostic synapomorphies of the Pinnipedimorpha but lacks all of the synapomorphies of the next most exclusive clade, the Unnamed Taxon that includes Pteronarctos and all other pinnipeds.

REVISED DIAGNOSIS OF GENUS.-The following attributes retained by Enaliarctos are primitive relative to those of other pinnipeds: deep embrasure pit between $\mathrm{P}^{4}$ and $\mathrm{M}^{1} ; \mathrm{P}^{4}-\mathrm{M}^{2}$ with multiple roots; $\mathrm{P}^{4}$ with shelf-like protocone; $\mathrm{M}_{1}$ with welldeveloped cusps on the trigonid and a hypoconid present on the talonid; six lumbar vertebrae; ulna lacking the posteriorly expanded olecranon process; radius lacking a strongly flattened and expanded distal end; fifth intermediate phalanx of the manus unreduced; femur with well-developed pit on the head for the teres femoris ligament; metapodial shafts rounded in cross section with keeled heads and strongly trochleated phalangeal articulations.

COMMENTS.-Because there are no unequivocal synapomorphies that diagnose Enaliarctos* I have recognized this taxon as a metataxon. Enaliarctos* was originally diagnosed by characters that now appear to be apomorphic at a more general level than was evident when Mitchell and Tedford's (1973) original description appeared. Supplemental descriptions by Barnes (1979) do not provide any other characters that can be interpreted as synapomorphies.

\section{Enaliarctos emlongi, new species}

\section{FiguRES 3-10}

DiAGNOSIS.-Distinguished from other species of Enaliarctos by having $\mathrm{P}^{3}$ with broadly developed posterolingual shelf, $\mathrm{P}^{2-3}$ with large crest-like metacone, $\mathrm{P}_{3-4}$ metaconid small, $\mathrm{M}_{1}$ metaconid very reduced and close to protoconid. Distinguished from all other species except $E$. mitchelli in having posterior portion of zygoma that joins palate anterior to $\mathrm{M}^{1}$. Distinguished from $E$. barnesi and $E$. mealsi in having reduced cheek teeth cingula, $\mathrm{P}^{4}$ with a short metacone.

TYPE MATERIAL.-Holotype: USNM 250345 (Emlong field no. E-53), a nearly complete cranium and jaws. Probably from the same individual, there is a left femur and right patella, tibia, and fibula (Emlong field no. E-70). Collected by Douglas Emlong, fall, 1961.

ETYMOLOGY.-The species is named in honor of Douglas Emlong for a lifetime devoted to the collection of fossil marine mammals from Oregon and his recognition of their value to science.

TYPE LOCALITY.-Cranium and jaws found in place in concretionary bank about $2 \mathrm{ft}[60 \mathrm{~cm}]$ above beach level and 50 $\mathrm{ft}[15 \mathrm{~m}]$ south of highest part of concretionary bluff, and postcranial elements found $5 \mathrm{ft}[1.5 \mathrm{~m}]$ from skull, approximately $1 / 4 \mathrm{mi}[400 \mathrm{~m}$ ] south of Big Creek, Lincoln County, Oregon. SE $1 / 4, S W^{1} / 4$, Sec. 32, T. 10 S, R. 11 W, Yaquina

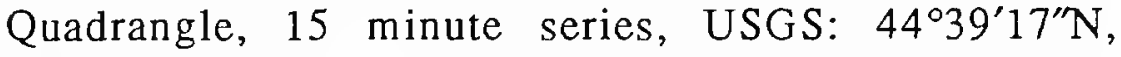
$124^{\circ} 04^{\prime} 42^{\prime \prime} \mathrm{W}$.

HorizoN.-Just north of Astoria Formation-Nye Mudstone contact. According to Emlong's field notes this locality is in the Astoria Formation; Repenning (pers. comm.) suggests it may in fact be from the Nye Mudstone.

REFERRED SPECIMENS.-USNM 314540 (E-76-38), crushed

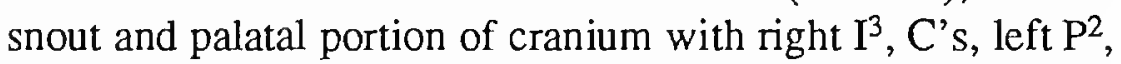
and $\mathrm{M}^{1}$, collected by Douglas Emlong on 22 May 1976. According to Emlong's field notes this specimen was collected in place in bedrock (Nye Mudstone) at floor of beach, $75 \mathrm{ft}[23$ $\mathrm{m}]$ out from bank, $2 / 3 \mathrm{mi}$ [1.07 km] south of Big Creek, Lincoln County, Oregon. NW $1 / 4, \mathrm{NW}^{1} / 4$, Sec. 5, T. $11 \mathrm{~S}, \mathrm{R} .11 \mathrm{~W}$, Yaquina Quadrangle, 15 minute series, USGS: $44^{\circ} 38^{\prime} 58^{\prime \prime} \mathrm{N}$, $124^{\circ} 03^{\prime} 36^{\prime \prime} \mathrm{W}$.

USNM 314290 (E-71-58), crushed skull with left $\mathrm{P}^{3}, \mathrm{P}^{4}$, and $\mathrm{M}^{1}$ collected by Douglas Emlong on 30 November 1971. According to Emlong's field notes this specimen was collected in a fine-grained sandstone layer that alternates with coarser grey sandstone containing large concretions between typical Nye Mudstone and Yaquina Formation, approximately $1 / 4 \mathrm{mi}$ [400 m] south of Beaver Creek, Lincoln County, Oregon. $\mathrm{NW}^{1} / 4$, Sec. 19, T. 12 S, R. $11 \mathrm{~W}$, Yaquina Quadrangle, 15 minute series, USGS: $44^{\circ} 31^{\prime} 00^{\prime \prime} \mathrm{N}, 124^{\circ}, 04^{\prime} 42^{\prime \prime} \mathrm{W}$.

DESCRIPTION. - The pattern of suture closure (see Sivertson, 1954 ) in the holotype indicates that it is an adult. The rostrum is broad and low and the narial opening is ovoid (Figure 3; Tables 2-4 ). The nasals are relatively long and narrow. The fusion of sutures has obscured the frontal-nasal contact. The nasolabialis fossa is well developed and positioned on the maxilla above the antorbital rim (Figure 3 ). The posteroventral margin of this fossa forms a strong antorbital ridge whereas the anterodorsal margin is produced into a thickened protuberance.

The narrow interorbital region is marked by small, rounded supraorbital ridges (Figure 3). The sagittal crest begins just 

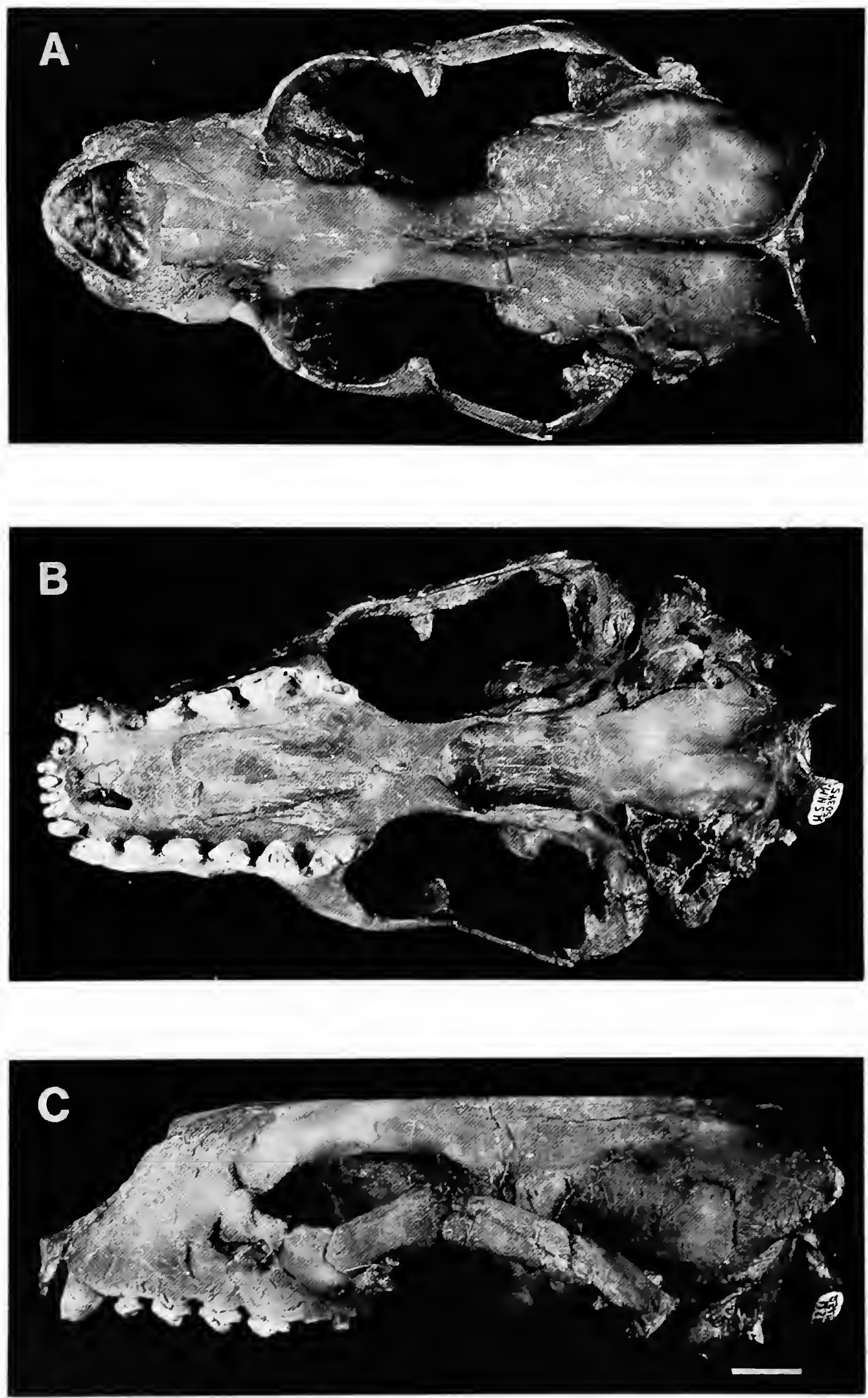

FIGURE 3.-Enaliarctos emlongi, new species, USNM 250345, holotype, skull: A, dorsal view; B, ventral view; C, lateral view. $($ Scale $=2 \mathrm{~cm}$.) 
TABLE 2.-Cranial measurements ( $\mathrm{mm}$ ) of Enaliarctos from coastal Oregon (e = estimated).

\begin{tabular}{|c|c|c|c|c|}
\hline Measurements & $\begin{array}{c}\text { E. emlongi } \\
\text { USNM } 250345\end{array}$ & $\begin{array}{c}\text { E. barnesi } \\
\text { USNM } 314295\end{array}$ & $\begin{array}{c}\text { E. ledfordi } \\
\text { USNM } 206273\end{array}$ & $\begin{array}{c}\text { E. mitchelli } \\
\text { USNM } 175637\end{array}$ \\
\hline Cranium length (CBL) & 228.00 & & & 172.06 \\
\hline Greatest width at antcrior nares & 32.30 & $37.18^{e}$ & & 30.08 \\
\hline Width across antorbital processes & 42.40 & 56.30 & 43.16 & 38.24 \\
\hline Width across greatest interorbital constriction & 22.26 & 28.99 & 21.06 & 18.83 \\
\hline Width across supraorbital processes & 28.97 & 40.13 & 28.16 & 22.86 \\
\hline Width of braincase at anterior edge of glenoid fossa & 66.59 & & 63.82 & $68.59^{e}$ \\
\hline Postpalatal length (postpalatal notch to basion) & 100.82 & & 99.99 & $76.64^{e}$ \\
\hline Width of rostrum across canines & 55.43 & 58.39 & & $39.63^{e}$ \\
\hline Zygomatic width & $126.00^{c}$ & & 123.70 & $91.37^{e}$ \\
\hline Auditory width & 87.79 & & 91.85 & $68.00^{e}$ \\
\hline Mastoid width & 103.14 & & 105.84 & \\
\hline Width of zygomatic root of maxilla & 16.36 & 14.92 & 15.32 & 13.47 \\
\hline Basion to anterior edge of zygomatic root & 152.61 & & 142.90 & 117.49 \\
\hline Width of palate across anterior root of $\mathrm{P}^{4}$ & 56.36 & $49.75^{e}$ & 51.97 & 43.22 \\
\hline Width between infraorbital foramen & 59.31 & $56.95^{e}$ & 58.95 & 44.81 \\
\hline Greatest width across occipital condyles & 51.12 & & 53.72 & \\
\hline Greatest width of foramen magnum & 21.08 & & 25.67 & 24.63 \\
\hline Greatest height of foramen magnum & 20.36 & & 16.03 & 18.62 \\
\hline Transverse diamenter of infraorbital foramen & $10.86^{e}$ & 9.83 & 9.70 & 10.23 \\
\hline Length of toothrow, $\mathrm{C}-\mathrm{M}^{2}$ & 78.18 & $69.27^{e}$ & & $63.56^{e}$ \\
\hline
\end{tabular}

TABLE 3.-Measurements ( $\mathrm{mm}$ ) of the upper dentition of Enaliarclos from coastal Oregon ( $\mathrm{a}=$ alveolus only; e = estimated).

\begin{tabular}{|c|c|c|c|c|c|}
\hline & & $\begin{array}{c}\text { E. emlongi } \\
\text { USNM } 250345\end{array}$ & $\begin{array}{c}\text { E. barnesi } \\
\text { USNM } 314295\end{array}$ & $\begin{array}{c}\text { E. tedfordi } \\
\text { USNM } 206273\end{array}$ & $\begin{array}{c}\text { E. mitchelli } \\
\text { USNM } 175637\end{array}$ \\
\hline $\mathrm{I}^{1}$ & $\begin{array}{l}\text { length } \\
\text { width }\end{array}$ & $\begin{array}{l}5.42 \\
2.69\end{array}$ & & & \\
\hline$r^{2}$ & $\begin{array}{l}\text { length } \\
\text { width }\end{array}$ & $\begin{array}{l}5.82 \\
3.33\end{array}$ & $\begin{array}{l}5.01 \\
3.09\end{array}$ & & \\
\hline $\mathrm{I}^{3}$ & $\begin{array}{l}\text { length } \\
\text { width }\end{array}$ & $\begin{array}{l}7.57 \\
5.40\end{array}$ & $\begin{array}{l}6.90 \\
5.00\end{array}$ & & \\
\hline C & $\begin{array}{l}\text { length } \\
\text { width }\end{array}$ & $\begin{array}{r}10.65 \\
7.65\end{array}$ & $\begin{array}{l}10.74 \\
10.74\end{array}$ & & $\begin{array}{l}7.50^{\circ} \\
7.50^{\circ}\end{array}$ \\
\hline $\mathrm{P}^{1}$ & $\begin{array}{l}\text { length } \\
\text { width }\end{array}$ & $\begin{array}{l}8.35 \\
5.74\end{array}$ & $\begin{array}{l}8.52 \\
6.18\end{array}$ & & $\begin{array}{l}6.25^{\mathrm{a}} \\
3.88^{\mathrm{a}}\end{array}$ \\
\hline $\mathrm{P}^{2}$ & $\begin{array}{l}\text { length } \\
\text { width }\end{array}$ & $\begin{array}{r}11.72 \\
5.80\end{array}$ & $\begin{array}{r}11.05 \\
6.12\end{array}$ & & $\begin{array}{l}8.74 \\
4.50\end{array}$ \\
\hline $\mathrm{P}^{3}$ & $\begin{array}{l}\text { length } \\
\text { width }\end{array}$ & $\begin{array}{r}12.10 \\
7.13\end{array}$ & $\begin{array}{r}10.61 \\
7.06\end{array}$ & $\begin{array}{l}7.36^{\mathrm{a}} \\
5.25^{\mathrm{a}}\end{array}$ & $\begin{array}{l}8.90 \\
5.26\end{array}$ \\
\hline $\mathrm{P}^{4}$ & $\begin{array}{l}\text { length } \\
\text { width }\end{array}$ & $\begin{array}{r}12.15 \\
9.87\end{array}$ & $\begin{array}{r}11.94 \\
9.01\end{array}$ & $\begin{array}{r}11.51 \\
8.64\end{array}$ & $\begin{array}{l}9.90 \\
7.08\end{array}$ \\
\hline $\mathrm{M}^{1}$ & $\begin{array}{l}\text { length } \\
\text { width }\end{array}$ & $\begin{array}{l}6.86^{\mathrm{a}} \\
9.04^{\mathrm{a}}\end{array}$ & $\begin{array}{l}7.04 \\
8.62\end{array}$ & $\begin{array}{l}5.20^{2} \\
7.90^{\circ}\end{array}$ & $\begin{array}{l}7.31 \\
4.83\end{array}$ \\
\hline $\mathrm{M}^{2}$ & $\begin{array}{l}\text { length } \\
\text { width }\end{array}$ & $\begin{array}{l}4.15 \\
3.92\end{array}$ & $\begin{array}{l}3.33^{\mathrm{a}} \\
2.45^{\mathrm{a}}\end{array}$ & & $\begin{array}{l}3.39^{\mathrm{a}} \\
2.00^{\mathrm{a}}\end{array}$ \\
\hline
\end{tabular}


TABLE 4.-Measurements $(\mathrm{mm})$ of the mandible and lower dentition of Enaliarctos from coastal Oregon.

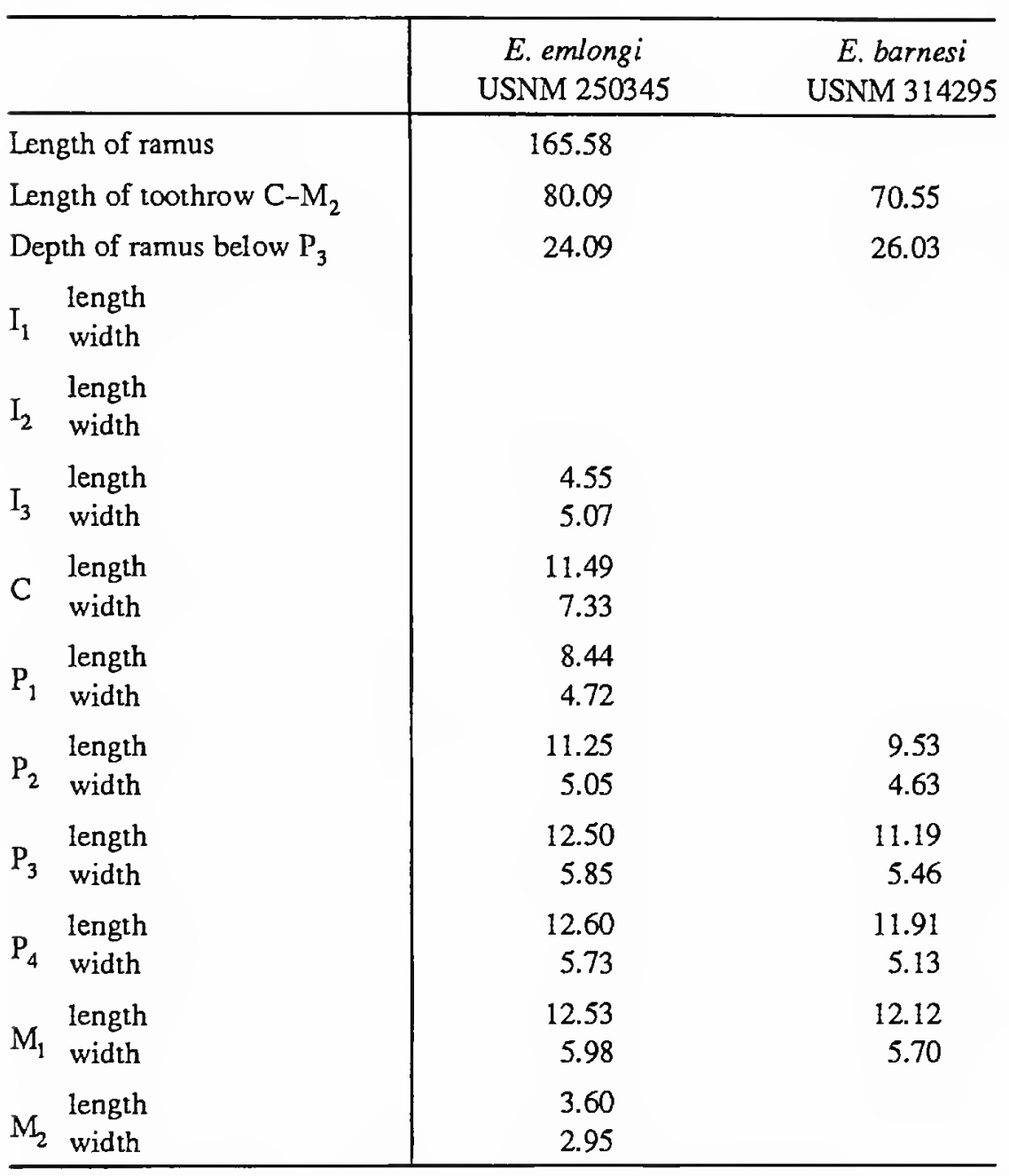

behind the supraorbital ridges and extends as a low ridge back to the lambdoidal crest. The posterior surfaces of the braincase are elevated above the anterior surface and the parietals are raised into a prominent lambdoidal crest. A pair of deep pseudosylvian sulci are obliquely positioned on the lateral surface of the braincase above the squamosal (Figure 3). The exoccipital portion of the occipital shield is broad and low. A short median supraoccipital crest separates the dorsal portion of the shield. Beneath the lambdoidal crest the shield is concave becoming convex above the nearly circular foramen magnum.

The zygomatic arch is less bowed laterally and less curved dorsally than in E. mealsi (Mitchell and Tedford, 1973, fig. 6). The ventral portion of the arch is slightly curved anterodorsally where it rises from the side of the skull. The posterior border of the zygomatic arch joins the palate between $\mathrm{M}^{1}$ and $\mathrm{M}^{2}$. The maxillary-jugal suture is fully closed and cannot be traced. The narrow tip of the zygomatic process of the squamosal contacts the base of the postorbital process of the jugal in a splint-like arrangement. Large postglenoid processes are present. A small postglenoid foramen is positioned at the lateral termination of a transverse groove across the postglenoid process.

The entire orbital region is mediolaterally compressed. The orbital wall is solid with no vacuities. Sutures in this region are not preserved. There is no indication of a lacrimal foramen or bone nor a pit for the inferior oblique muscles. The large infraorbital canal is nearly circular in outline. The sphenopalatine foramen is relatively large and ovoid. The smaller posterior palatine foramen is positioned anterior and slightly ventral to it.

The palate is slightly arched dorsally for its entire length (Figure 3). The incisive foramina have large, paired palatal openings separated by a narrow crest of bone. The anterior palatine foramina and their associated sulci originate medial to $\mathrm{P}^{4}$ and terminate medial to $\mathrm{P}^{2}$. Several smaller posterior foramina are on either side of the palate. Small, rounded palatine processes of the maxilla extend a short distance behind $\mathrm{M}^{2}$. The posterior border of the palate is $\mathrm{U}$-shaped and a very small median tuberosity projects slightly posteriorly.

The palatine, alisphenoid, pterygoid strut between the palate and the braincase is inflated with a rounded, convex lateral margin (Figure 3). Most of the pterygoid hamulus is broken off. The basioccipital is rectangular and characterized by having a horizontal flange that abuts the entotympanic. Located posteriorly and separated by a thick median crest are a pair of very deep depressions for the rectus capitis muscles. Positioned at the anterior end of these depressions are a pair of small tuberosities. The presence of similar tuberosities in E. mealsi, Pinnarctidion bishopi, and Pteronarctos goedertae were noted by Barnes (1979:26, 1989:9), who discovered that dorsal to these tuberosities are matrix filled cavities in the basioccipital. Barnes suggested that these cavities may be homologous with the embayment of the inferior petrosal venous sinus for a loop of the internal carotid artery seen in ursids and amphicyonids (see Hunt, 1974a,b, 1977). A more detailed evaluation of this character and its distribution is currently in progress (Berta, in prep.). A pair of ellipsoidal hypoglossal foramina are positioned along the posterolateral margin of the basioccipital.

The tympanic bullae are large, flask-shaped, and medially inflated (Figure 3). A steep crest of the bulla forms a groove that joins the bulla to the postglenoid process. Posterolaterally, the bulla is fused to the mastoid and paroccipital processes. The mastoid process is considerably larger than the paroccipital process and connected to it by a very low, broad ridge (Figures $3,4)$. The paroccipital process is short, blunt, and directed posteroventrally. Several small foramina pierce the surface of that portion of the bulla that forms the tubular external auditory meatus. A flange of the bulla appears to have separated the median lacerate foramen from the eustachian tube although much of the flange is broken away. The posterior opening of the carotid canal is confluent with the enlarged jugular foramen. The fossa for the tympanohyal is located medial and slightly posterior to the large, deep, circular stylomastoid foramen. A very thin flange of bone separates them.

The ventral wall of the bulla on the right side of the holotype was removed to expose the middle ear cavity (Figure 4). The ventrolateral wall of the carotid canal creates a shelf in the medial wall of the bulla. The tympanic crest is considerably 


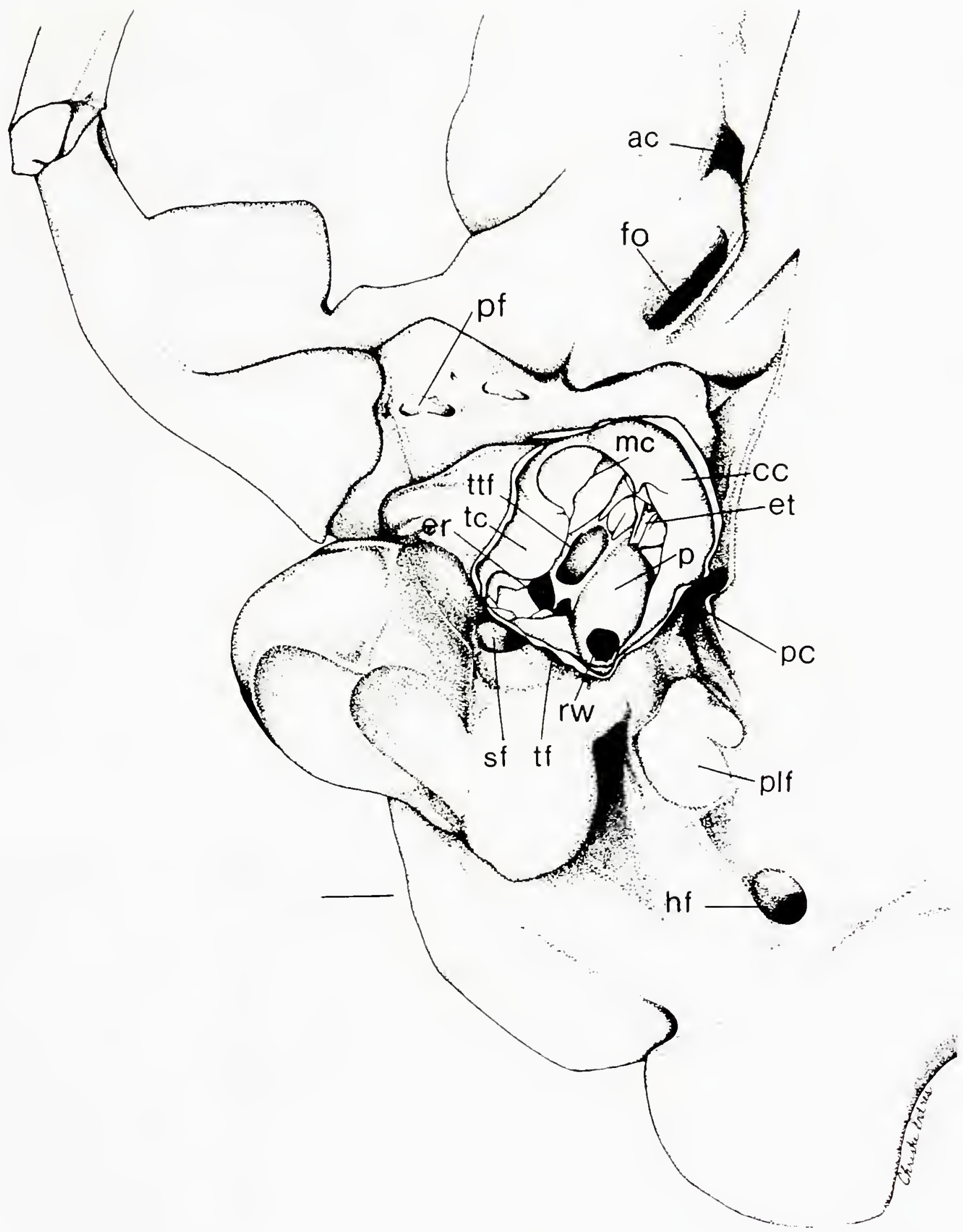

Figl'RE 4.-Enaliarctos emlongi, new species, LS.N. 250345, holotype, ventral view of right side of basicranium with ventral wall of bulla removed. (Abbreviations: ac = posterior opening of alisphenoid canal; cc = ventral wall of carotid canal; er = epitympanic recess; $\mathrm{et}=$ groove for eustachian tube; fo = foramen ovale; $\mathrm{hf}$ $=$ hypoglossal foramen; $m c=$ septum of musculotubarius canal; $\mathrm{p}=$ promontorium; $\mathrm{pc}=$ posterior opening of carotid canal; pf = postglenoid foramen; plf = postcrior lacerate foramen; $r w=$ round window; $s f=$ stylomastoid foramen; $t c=$ tympanic crest; $t f=$ tympanohyal fossa; $t u f=$ tensor tympani fossa. Scale is approximately $5 \mathrm{~mm}$.) 
larger than in E. mealsi and it projects farther into the tympanic cavity. In addition, the tympanic cavity differs from that of $E$. mealsi in its farther posterior extension.

The pear-shaped promontory is broader mediolaterally than in E. mealsi. The round window is posteriorly oriented and the smaller oval window faces laterally. Lateral to the promontory is a deep, elliptical fossa for the tensor tympani. Posterolateral to the fossa for the tensor tympani is the deep, nearly circular epitympanic recess. A shallow groove marks the anterior margin of this fossa and leads to the groove for the eustachian tube; its lateral margin defined by the septum of the musculotubarius canal. Several smaller grooves are developed on the anterior face of the promontory. The lateral groove, the largest, probably housed the internal carotid artery. A small opening, presumably the promontory foramen is visible in the posteromedial wall of the bulla.

The malleus and incus were recovered from the holotype in excellent condition (Figure 5). The muscular process is absent from the malleus. The anterior portion of the mallear head is relatively large and it bears a deep concavity. Although incomplete, it is apparent that a thin anterior lamina extends from the anterior process to the base of the neck. The manubrium is thin and relatively short. The incus is large and slightly inflated with a short, broad stapedial process and a long, thin posterior crus.

$\mathrm{I}^{1-3}$ are arranged in a broad transverse arc. $\mathrm{I}^{1-2}$ are distinguished by having a transverse groove that extends across the crown creating the effect of a double cusp (Figure 6). $\mathrm{I}^{3}$ is larger with a nearly circular crown. Deep vertical wear facets are developed on the lateral margins of the crown.
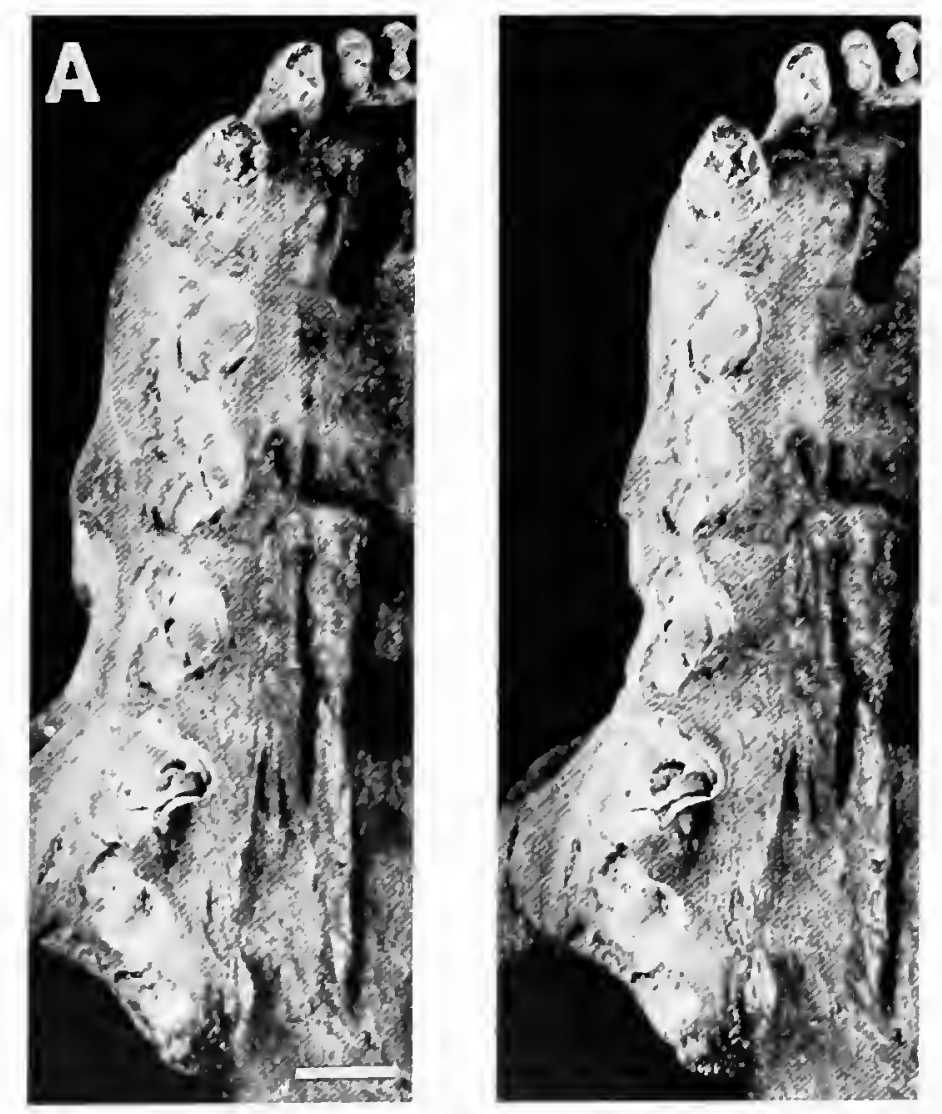

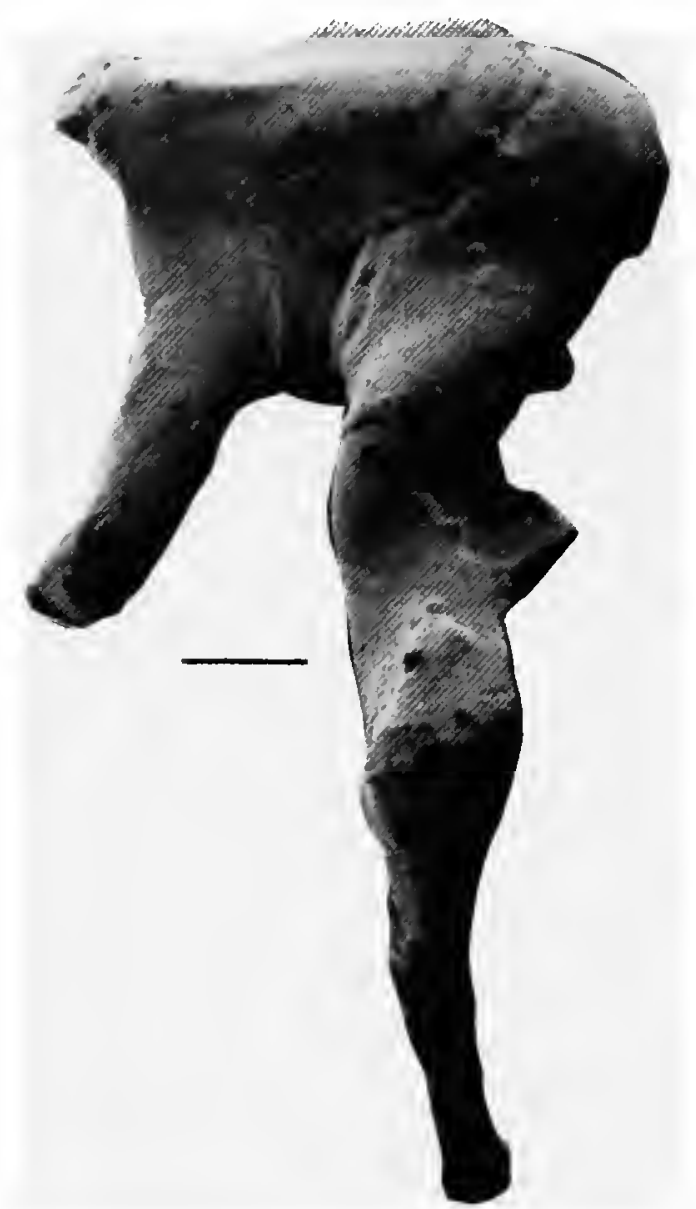

FIGURE 5.-Enaliarctos emlongi, new species, USNM 250345, holotype, malleus and incus. (Scale $=1 \mathrm{~mm}$.)

The canine is relatively large and slightly recurved. On the posterior side of the crown is a vertical crest that extends medially from the vertical crest to its termination midway around the lingual face of the tooth.
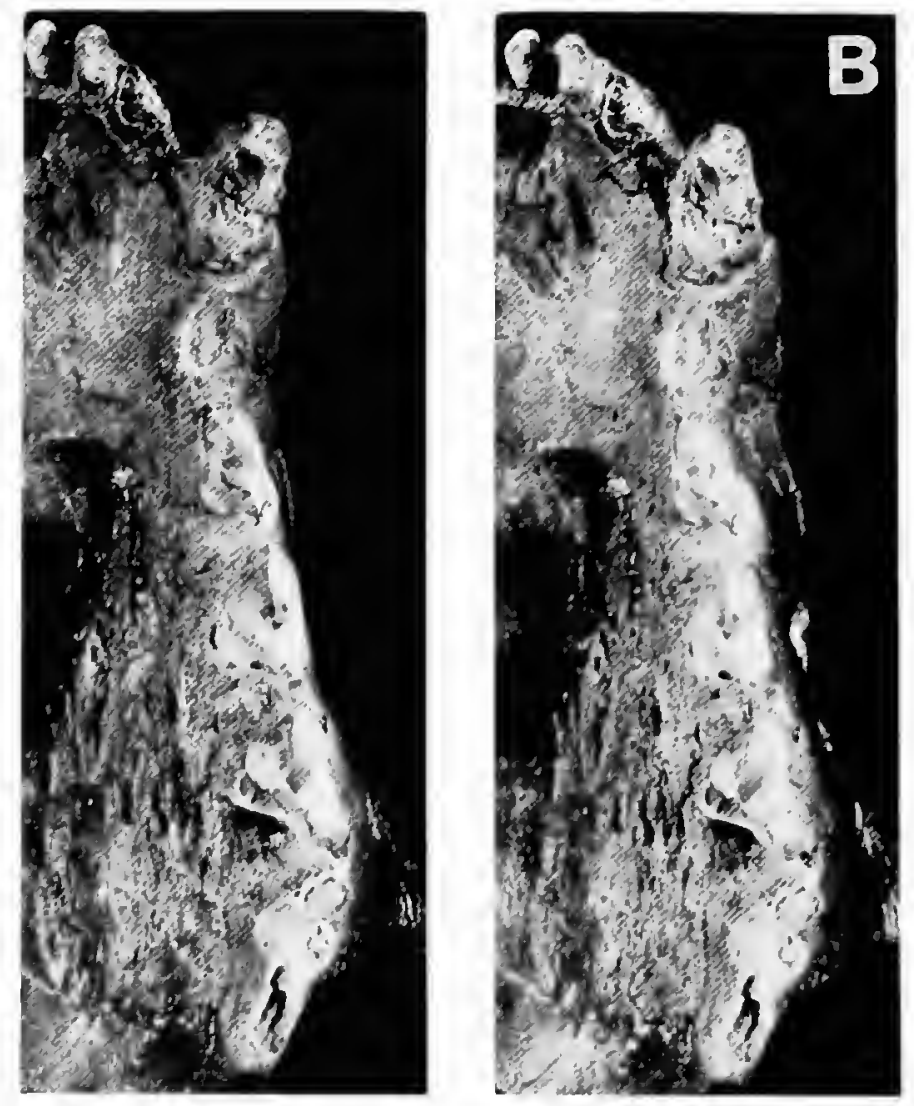

FlGURE 6-Stereophotographs of palate and upper dentition of Enaliarclos emlongi, new species, USNM 250345, holotype: A, right $\mathrm{I}^{1-3}, \mathrm{C}, \mathrm{P}^{1-4} ; \mathrm{B}$, left $\mathrm{I}^{1-3}, \mathrm{C}, \mathrm{P}^{1-4}$. (Scale $=1 \mathrm{~cm}$.) 
$\mathrm{P}^{1-3}$ are elongate and posteromedially broad with welldeveloped lingual cingula (Figure 6). $\mathrm{P}^{1}$, positioned directly behind the canine, is single rooted with a centrally positioned paracone. The tooth terminates in an upturned cingular heel. $\mathrm{P}^{2-3}$ are similar in size. $\mathrm{P}^{3}$ shows an increase in width postcrolingually and a more strongly developed crest-like metacone. $\mathrm{P}^{2-3}$ differ from $E$. mealsi in having a well-defined metacone separated from the paracone by a deep notch. The anterior premolars exhibit relativcly little wear.

$\mathrm{P}^{4}$ is three-rooted with a large conical paracone separated by a well-defined notch from the relatively large metacone (Figure $6)$. The protocone shelf is more broadly developed than in $E$. mealsi (Mitchell and Tedford, 1973, fig. 15). A large wear facet extends from the posterior protocone shelf along the occlusal face of the posterior paracone and metacone blades. No parastylc is developed. A lingual cingulum is present, differing from the condition in E. mealsi in which the tooth is encircled by strongly developed labial and lingual cingula. A relatively decp embrasurc pit is present on the palate between $\mathrm{P}^{4}$ and $\mathrm{M}^{1}$. $\mathrm{M}^{2}$, preserved on the right side is single rooted. A small pit in the palate in the position of the anterior root for $\mathrm{M}^{2}$ was judged pathologic given the presence of similar pits between $\mathrm{P}^{2}$ and $\mathrm{P}^{3}$. The tooth has a circular crown with low, flattened cusps. This tooth resembles an isolated $\mathrm{M}^{2}$ referred to $E$. mealsi by Mitchell and Tedford (1973:242). An anteriorly oriented paracone is separated by a cleft from the medially directed metacone. The talon is a broad protocone shelf.

Associated with the holotype are well-preserved, nearly complete mandibular rami (Figures 7, 8). The rami are relatively long and slender with teeth well spaced in the toothrow in comparsion to the short crowded toothrow in $E$. barnesi. The symphysis is shallow with a gently rounded ventral border. Although not well preserved in the holotype it is clear that two mental foramina were developed, a larger one below $\mathrm{P}_{2}$ and a smaller one below the anterior and posterior roots of $\mathrm{P}_{3}$. The coronoid process is broad at the base with a low, rounded apex. The pterygoid process is short and shallow and slopes ventromedially.

$\mathrm{I}_{3}$ is preserved on the right side (Figure 9). It is small and closely appressed to the canine with a triangular crown. The canine is relatively small with a recurved crown. A flat wear facet at the apex extends as a narrow, vertical strip to the base of the posterior part of the labial side of the crown. A large wear facet is also developed on the labial side of the crown extending from the apex to the base of the crown.

$P_{1}$ is single rooted and positioned directly behind the canine. The principal cusp is worn nearly to the level of the crown. A lingual cingulum is present that curves dorsally at the anterior and posterior ends of the tooth. $\mathrm{P}_{2-4}$ are double rooted and $\mathrm{P}_{3-4}$ are nearly the same size. Each tooth has a crown with three cusps, arranged anteroposteriorly, a small paraconid, a large protoconid, and a small metaconid positioned high on the tooth (Figure 9). The metaconid is smaller than the paraconid and positioned close to the protoconid. Lingual cingula are well
TABLE 5.-Measurements (cm) of postcranial elements of Enaliarctos emlongi, USNM 250345 ( $\mathrm{e}=$ estimated).

\begin{tabular}{l|r} 
Femur & \\
length & 13.20 \\
proximal width & 6.23 \\
proximal depth & 2.26 \\
distal width & 6.09 \\
distal depth & 2.49 \\
Tibia & \\
length & 23.90 \\
proximal width & $3.90^{e}$ \\
proximal depth & 3.81 \\
distal width & 3.34 \\
distal depth & 3.18 \\
Fibula & \\
length & 20.80 \\
proximal width & 3.22 \\
proximal depth & 1.62 \\
distal width & 2.34 \\
distal depth & 2.54 \\
Patella & \\
length & 3.65 \\
width & 3.08 \\
depth & 1.77
\end{tabular}

developed. The lower premolars differ from those of $E$. mealsi in having reduced cingula and a decrease in size of the paraconid and metaconid.

Although heavily worn $\mathrm{M}_{1}$ consisted of the same three cusps and differs from E. mealsi (Barnes, 1979, fig. 2) in having the metaconid not as well separated from the protoconid. The unicuspid talonid consists of a single, centrally positioned hypoconid. The talonid is relatively shorter than in E. mealsi. $\mathrm{M}_{2}$, represented only by an alveolus, indicates that this tooth had a single, bilobed root.

In addition to $E$. mealsi, the only other species of this genus represented by postcranial material is $E$. emlongi. Elements from the left and right hind leg (left femur, right tibia, fibula, and patella) were apparently recovered from the same individual as the holotype, based on locality and horizon provenance (Table 5). In most respects these elements compare very favorably with USNM 374272, a nearly complete skeleton of $E$. mealsi that has been recently described (Berta et al., 1989; Berta and Ray, 1990).

The femur is missing the anterior surface of the head, shaft, and distal end. It shows typical features seen in E. mealsi such as well developed foramen on the head for the ligamentum teres, a prominent lesser trochanter, and a strongly produced trochanteric fossa (Figure 10). Much of the lateral condyle of the tibia is missing and there is no evidence of proximal fusion of the tibia and fibula (Figure 10). The morphology of the distal articular surface of the tibia is better preserved than in $E$. mealsi. It is characterized by development of a deep, rectangular socket for articulation with the astragalas; in this respect it is more similar to ursids than other pinnipeds. Ursids differ, however, in having the lateral margin of the distal articular surface elongated whereas that of E. emlongi slopes 

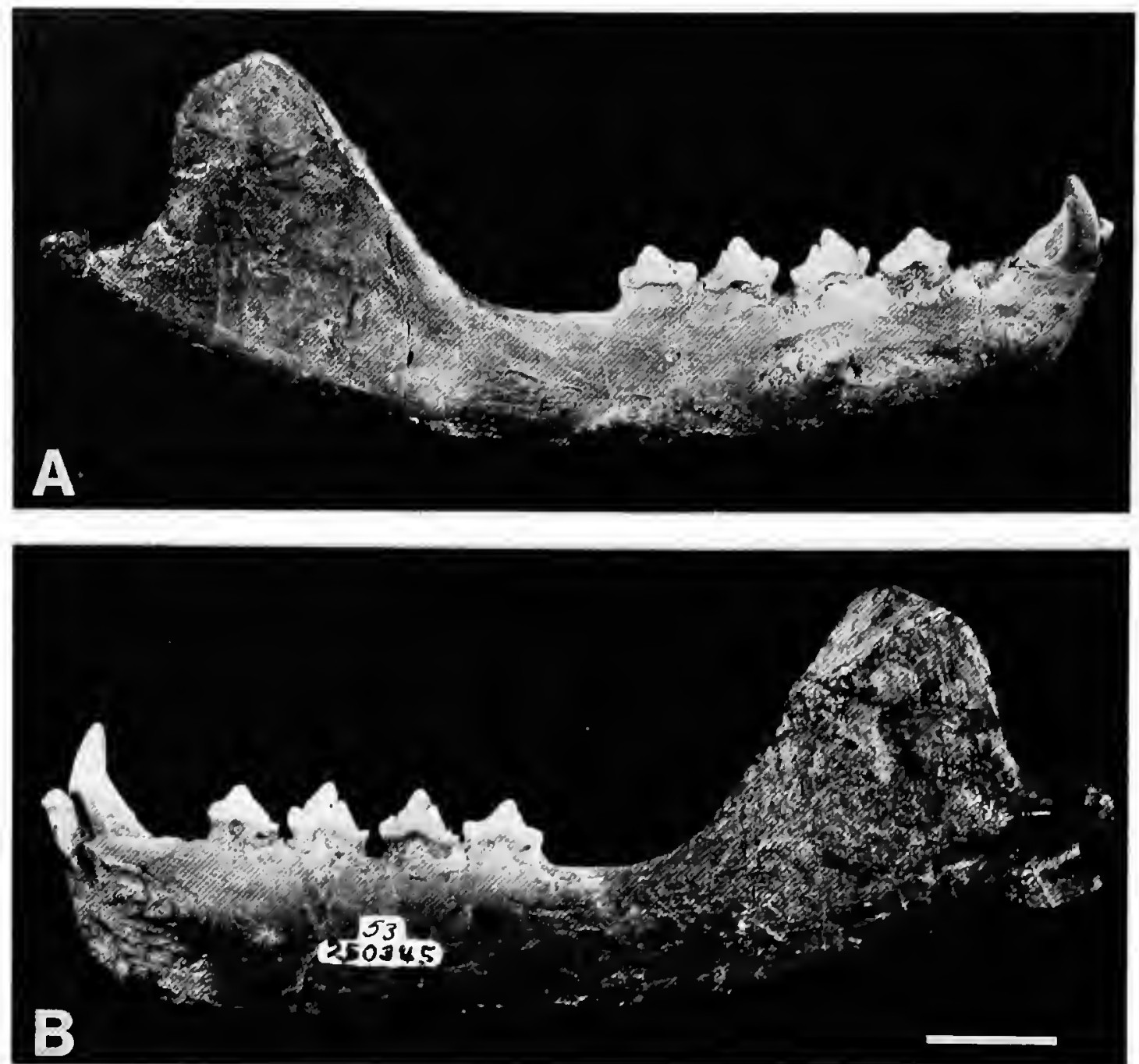

FIGURE 7.-Enaliarctos emlongi, new species, USNM 250345, holotype, right lower jaw: A, lateral view; B, medial view. (Scale $=2 \mathrm{~cm}$.)
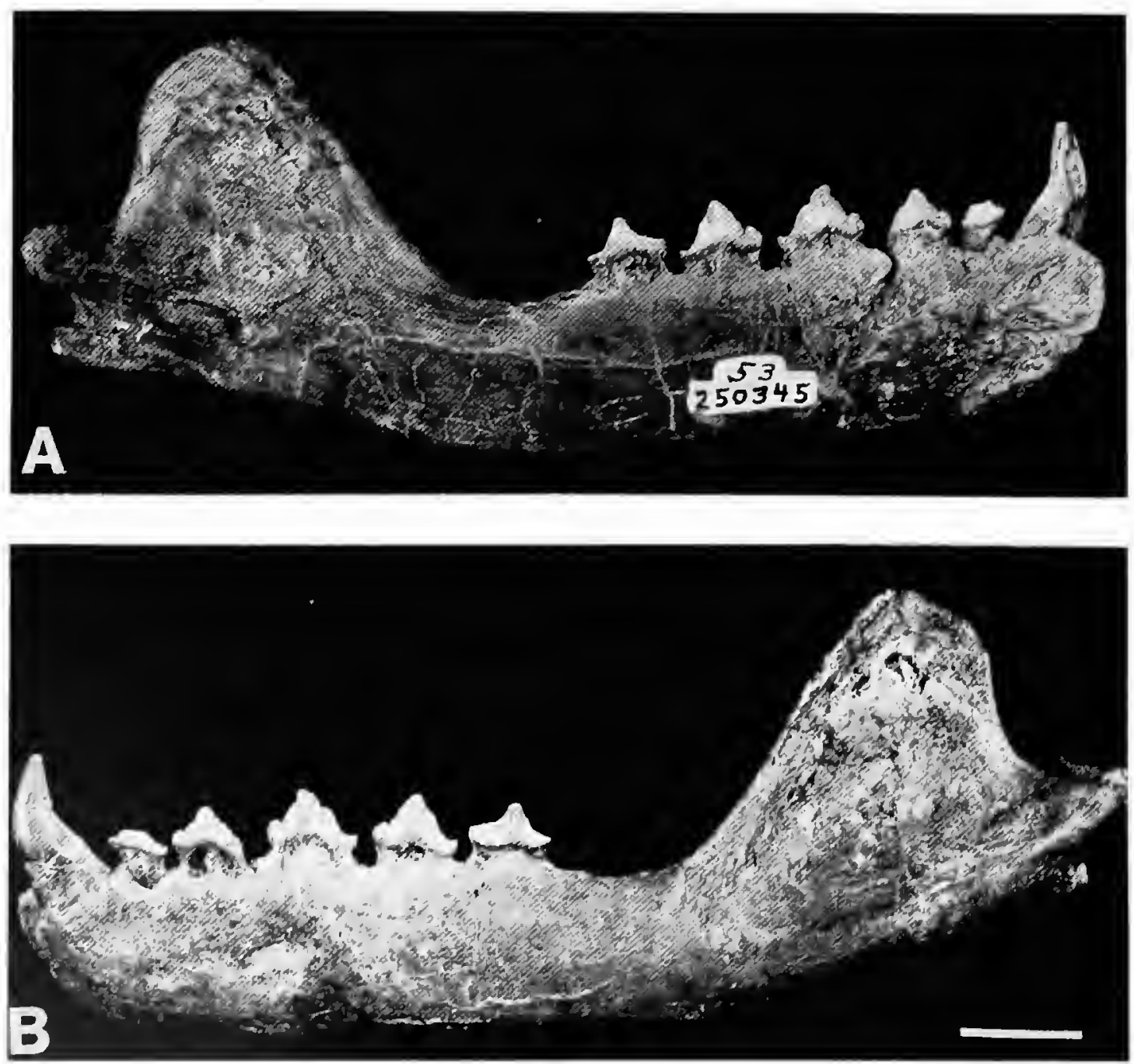

FIGURE 8. Enaliarctos emlongi, new species, USNM 250345, holotype, left lower jaw: A, medial view; B, lateral view. (Scale $=2 \mathrm{~cm}$.) 

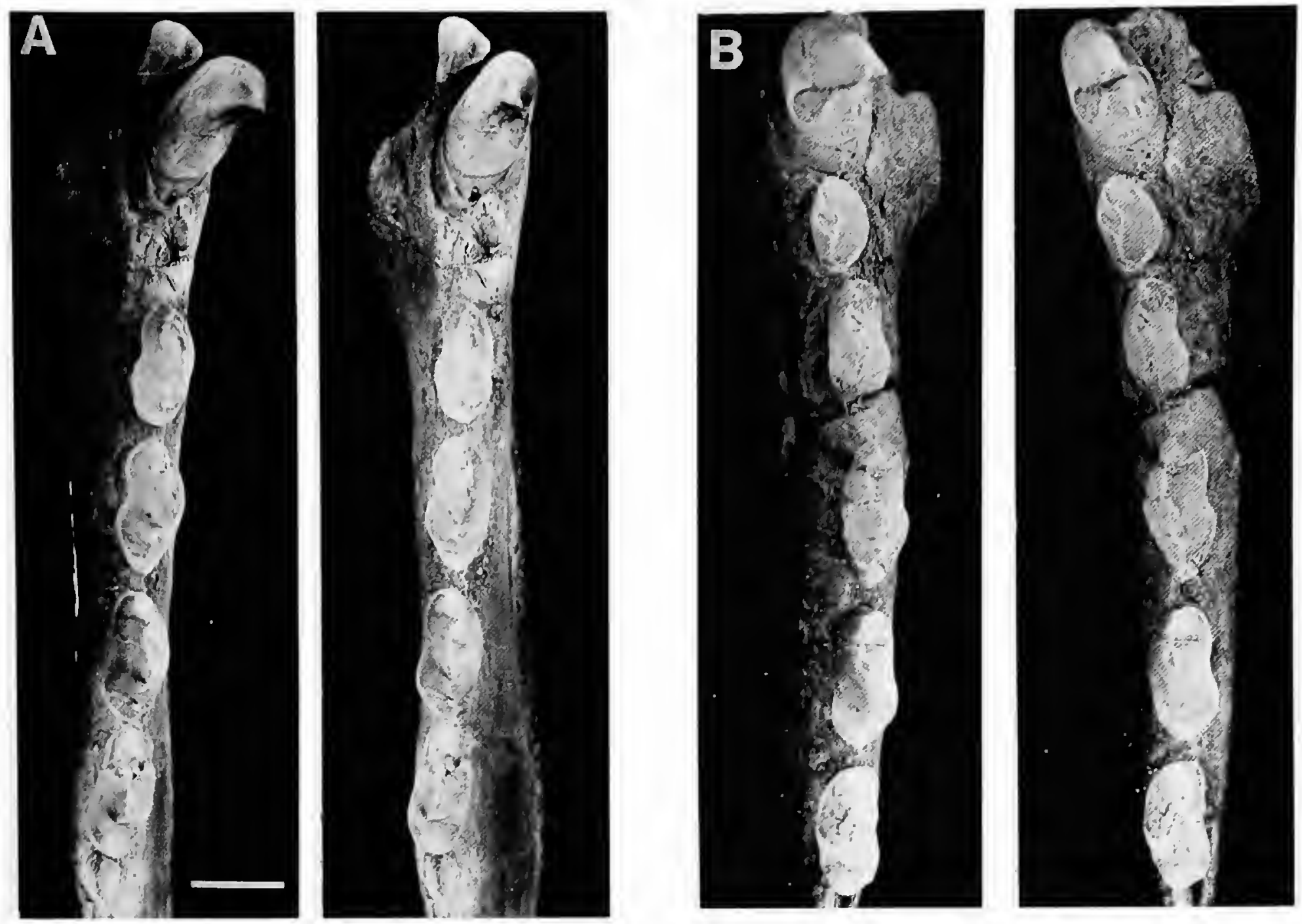

FIGURE 9.-Stereophotographs of lower dentition of Enaliarctos emlongi, new species, USNM 250345, holotype: $A$, right $I_{3}, C, P_{2-4}, M_{1} ; B$, left $C, P_{1-4}, M_{1}$. (Scale $=1 \mathrm{~cm}$.)

off abruptly. The fibula displays a well-defined processus lateralis fibulae at its distal end. The patella preserves an ossified portion of the patellar ligament on its anterior surface.

The referred snout and palate of E. emlongi (USNM 314540) is the same size as the skull of the holotype. $\mathrm{P}^{2}$ is posterolingually broad with a large protoconid and welldeveloped metacone on the heel. A large parastyle is present on $\mathrm{M}^{1}$.

The referred crushed skull (USNM 314290) is considerably smaller than either the holotype (USNM 250345) or the referred snout (USNM 314540) and undoubtedly represents an immature individual. The dentition is very similar to the holotype.

\section{Enaliarctos barnesi, new species}

FIGURES 11-15

DIAGNOSIS.-Distinguished from all other species of Enaliarctos in having spur-like palatine processes on maxilla, and short lower cheek tooth row. Distinguished from all species except $E$. emlongi in having a posterolingual shelf on $\mathrm{P}^{3}$. Distinguished from E. tedfordi, E. emlongi, and E. mitchelli in primitively retaining well-developed cheek teeth cingula, and having $\mathrm{P}^{4}$ with a long metacone.
TYPE MATERIAL.-Holotype: USNM 314295 (Emlong Field no. E-71-63), anterior half of cranium and associated mandibular rami; collected by Douglas Emlong on 13 December 1971.

ETYMOLOGY.-The species is named in honor of Lawrence $\mathrm{G}$. Barnes for his longstanding interest, collection, and study of fossil pinnipeds.

TYPE LOCALTTY.-Approximately $1 / 4 \mathrm{mi}[400 \mathrm{~m}]$ south of Beaver Creek, Lincoln County, Oregon. NE corner Sec. 24, T. 12 S, R. 12 W, Yaquina Quadrangle, 15 minute series, USGS: $44^{\circ} 31^{\prime} 06^{\prime \prime} \mathrm{N}, 124^{\circ} 04^{\prime} 40^{\prime \prime} \mathrm{W}$.

HORIZON.-In place in sandstone near the contact between the Nye Mudstone and the Yaquina Formation.

DESCRIPTION.-The cranium is broken obliquely through the anterior portion of the brain case and crushed and deformed dorsoventrally (Figure 11). All sutures except those bordering the nasals are fused, indicating that this animal was an adult. Measurements are listed in Tables 2-4.

The snout is similar in most respects to $E$. emlongi. The narial opening although distorted appears to have been low and ovoid. The nasals differ, however, in being short and broad, especially anteriorly (Figure 11). The nasal-frontal contact presents a truncate margin. Nasolabialis fossae are deep and their anterior margins form a very pronounced ridge on the 

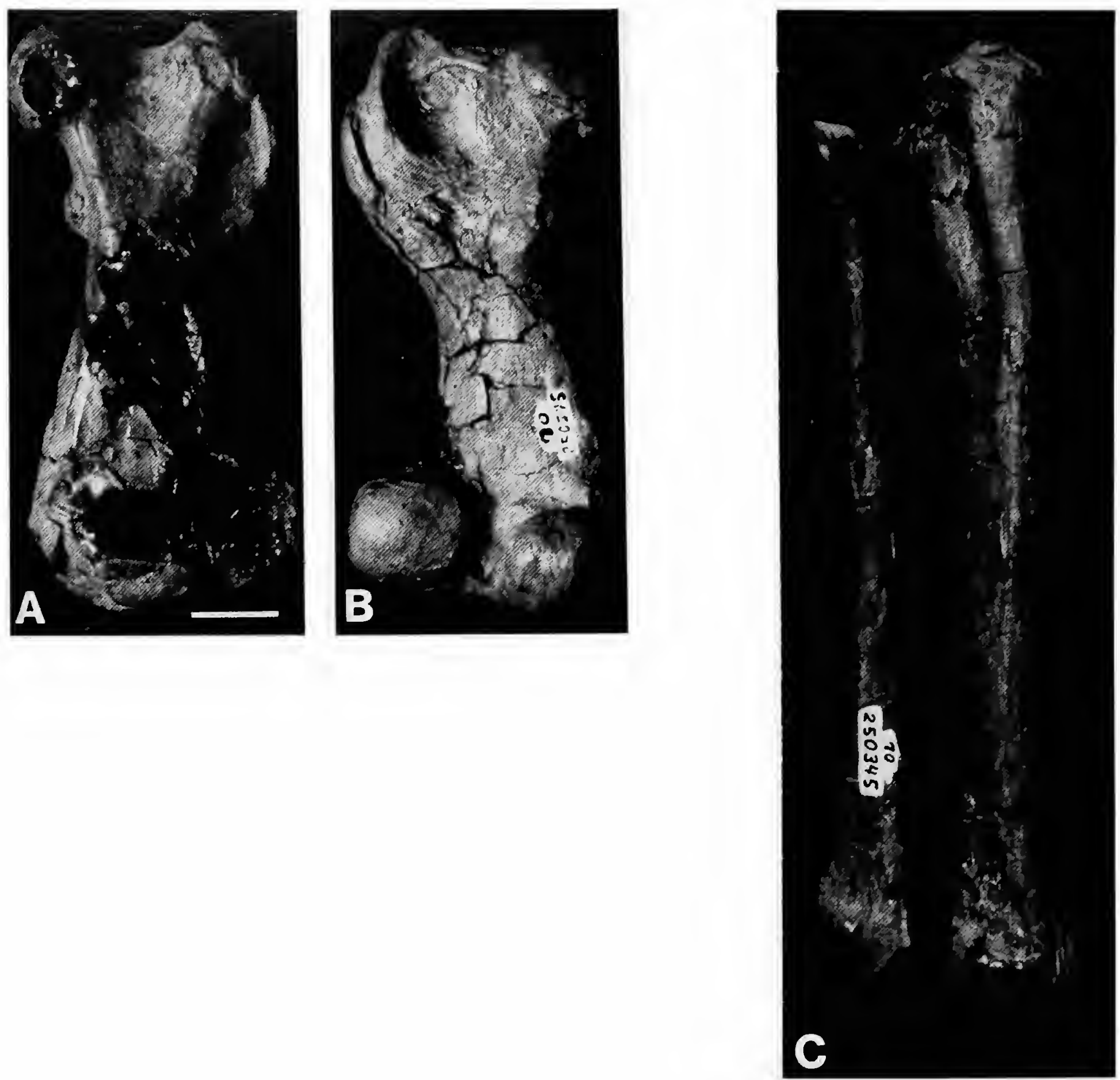

FIGURE 10.-Enaliarclos emlongi, new species, USNM 250345, holotype, associated postcranial elements: A, B, left femur, anterior and posterior views; $C$, right tibia and fibula, anterior view. (Scale $=2 \mathrm{~cm}$.)

dorsal face of the maxillary in addition to creating the more typical antorbital fossa posteriorly.

The interorbital region is narrow with small, inflated supraorbital processes anteriorly positioned (Figure 11). The sagittal crest begins posterior to the supraorbital ridges and extends posteriorly as a thin clevated ridge. The orbital region is solid and there is no indication of a lacrimal foramen. The infraorbital canal is narrowly ovoid and broader than it is high. Although distorted, it appears as though the zygomatic arch joins the palate between $\mathrm{P}^{4}$ and $\mathrm{M}^{1}$. The postorbital process of the jugal is dorsally curved; in this respect it is similar to $E$. mealsi (Mitchell and Tedford, 1973, fig. 6).
Both $\mathrm{I}^{2}$ and left $\mathrm{I}^{3}$ are preserved and positioned around a narrower arc than in E. emlongi (Figure 12). $\mathrm{I}^{2}$ is distinguished in having a transverse groove running across the crown. Incisive foramina are large and broad. The palate is crushed although it appears as though a single pair of anterior palatine foramina were present extending from $\mathrm{P}^{4}$ to $\mathrm{P}^{2}$. The palatine process of the maxilla projects as a spur of bone a short distance behind $\mathrm{M}^{2}$ (Figure 11).

The teeth are well-preserved and show relatively little wear. Coarsely crenulate enamel especially on the labial portions of the tooth crowns is evident as are well-developed labial and lingual cingula completely encircling the teeth (Figure 12).

The lingual cingulum and vertical crest are prominent 

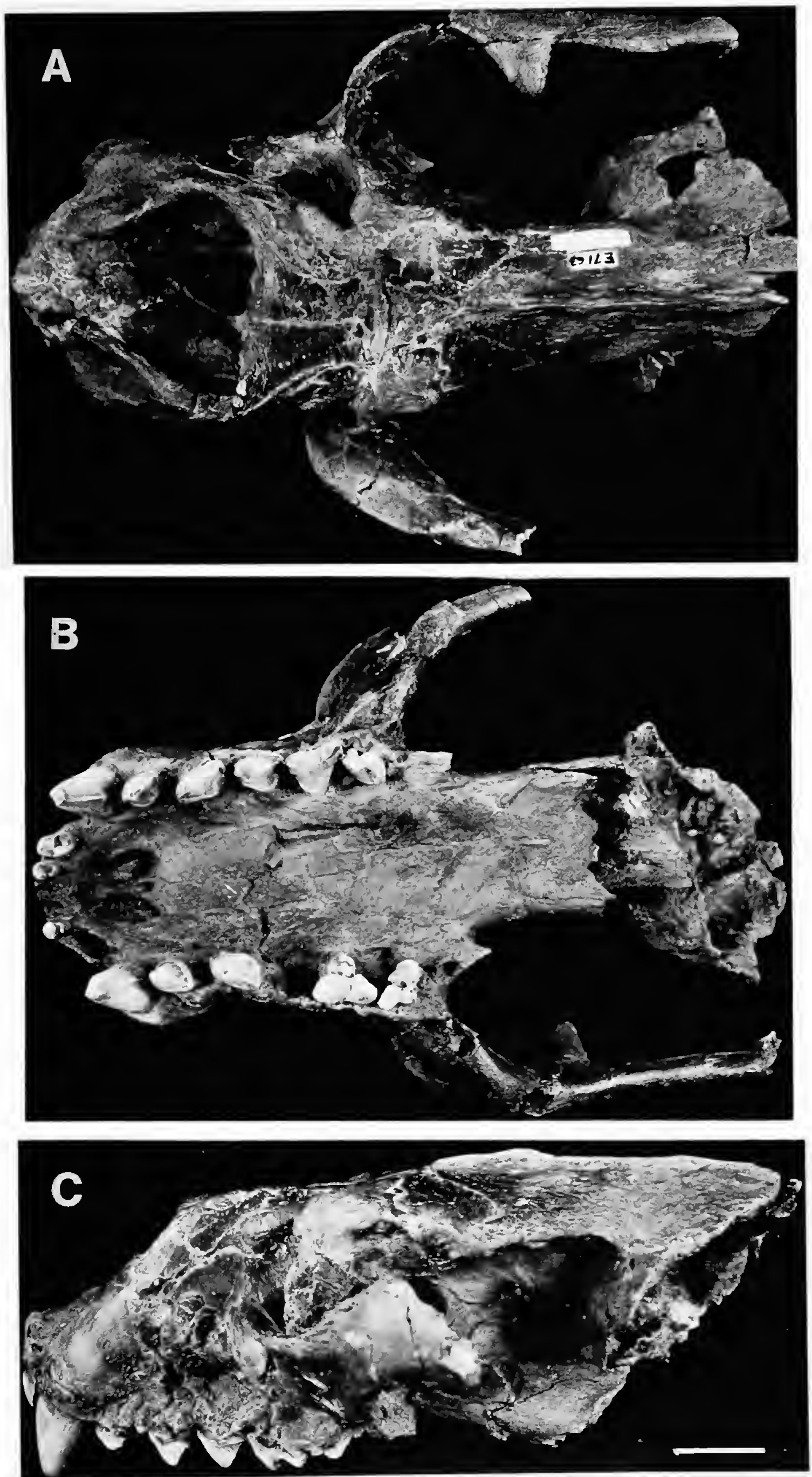

FIGURE 11.-Enaliarctos barnesi, new species, USNM 314295, holotype, anterior skull: A, dorsal view; B, ventral view; $C$, lateral view. (Scale $=2 \mathrm{~cm}$.) 

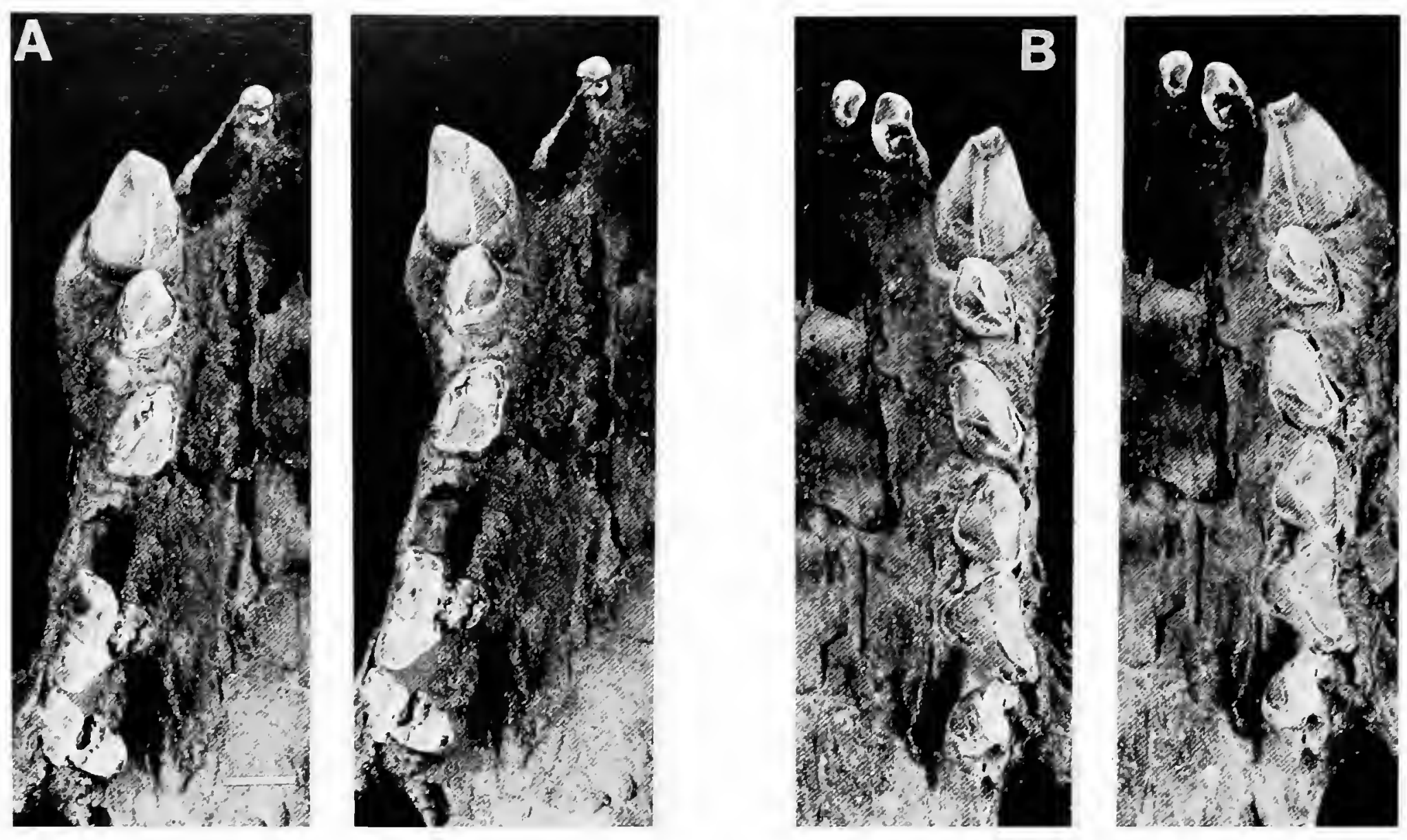

FIGURE 12. -Stereophotographs of palate and upper dentition of Enaliarctos barnesi, new species, USNM 314295, holotype: A, right $I^{2}, C, P^{1-2}, P^{4}, M^{1}, B$, left $I^{1}, I^{3}, C, P^{1-4}, M^{1} .($ Scale $=1 \mathrm{~cm}$.

features of the canines. Along the anteromedial side of the canine is a large, rectangular vertical wear facet that extends from the base of the crown to the flattened apex.

The premolars differ from those of $E$. emlongi in being relatively shorter and broader posterolingually (Figure 12, Table 3). $\mathrm{P}^{2}$ and $\mathrm{P}^{3}$ are simpler in construction than those of $E$. emlongi and consist of a single cusp, the paracone. In this feature $E$. barnesi differs from $E$. mealsi, which possesses a very small metacone, and $E$. emlongi, in which this cusp forms a large, well-developed crest. $\mathrm{P}^{4}$ differs from that of $E$. emlongi in having a relatively longer metacone, in this feature $E$. barnesi resembles $E$. mealsi. A deep embrasure pit is present betwen $\mathrm{P}^{4}$ and $\mathrm{M}^{1}$ (Figure 12). The first upper molar is considerably smaller than $\mathrm{P}^{4}$. It is double rooted with a single large anterior root and fused posterior roots. In most respects it compares well with that of $E$. mealsi with a parastyle, large paracone, small metacone, and protocone; the latter cusp largely obscured by wear. This tooth differs from its counterpart in the holotype of $E$. mealsi in having a reduced protocone shelf and in having the entire talon shifted further posteriorly. The $\mathrm{M}^{1}$ is, however, similar in morphology to an isolated specimen referred to E. mealsi by Barnes (1979, fig. 2). The $\mathrm{M}^{2}$ alveolus is preserved on the right side and it indicates that this tooth was single rooted and elongate.

Left and right mandibular rami are associated with USNM 314295 (Figures 13, 14). The left side lacks the condyle, the incisors, and $\mathrm{M}_{2}$ whereas the right side is missing the ramus anterior to $\mathrm{P}_{2}$. The ramus differs from $E$. emlongi in being more robust, especially along the ventral border and in having a relatively short toothrow. Two mental foramina are preserved just below the midpoint of the horizontal ramus. The larger one is positioned below the posterior root of $\mathrm{P}_{2}$ and the smaller one is below the anterior and posterior roots of $\mathrm{P}_{3}$.

The alveoli for $\mathrm{I}_{2-3}$ indicate that these teeth were positioned very close to the canine. The canine is similar to that of $E$. emlongi but differs in being proportionally broader at the base, especially across the posterior part of the tooth.

The $\mathrm{P}_{1}$ is missing and the alveolus is resorbed. $\mathrm{P}_{2-4}$ differ from that of $E$. emlongi in having more strongly developed cingula and larger paraconids and metaconids (Figure 15); in these features resembling $E$. mealsi.

The $M_{1}$ is distinguished in having a large trenchant paraconid and protoconid and a smaller metaconid medially positioned just behind the protoconid. The talonid is longer than in E. emlongi and it consists of a single central cusp, the hypoconid. The $\mathrm{M}_{2}$ alveolus indicates that this tooth had a single bilobed root.

\section{Enaliarctos tedfordi, new species}

Figures 16,17

DIAGNOSIS,-Distinguished from other species of $E n$ - 

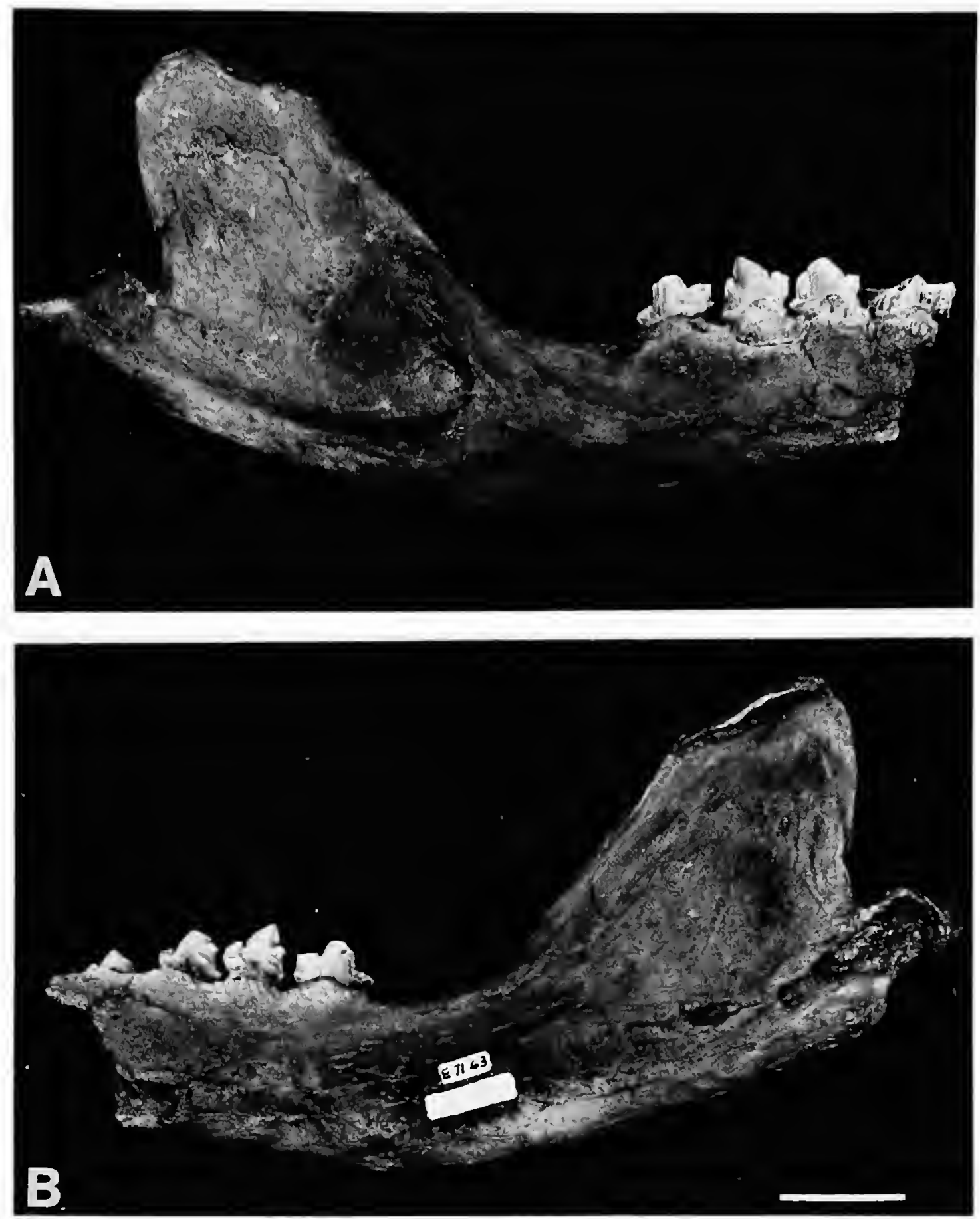

FlGURE 13.-Enaliarctos barnesi, new species, USNM 314295, holotype, right lower jaw: A, lateral view; B, medial view. $($ Scale $=2 \mathrm{~cm}$.)

aliarctos by having smaller, less well-developed metacone crests on $\mathrm{P}^{2-3}$. Distinguished from $E$. mitchelli in primitively retaining dorsally arched ventral portion of zygoma and having posterior portion of palate joining palate between the roots of $\mathrm{M}^{1}$. Distinguished from $E$. mealsi and $E$. barnesi in having reduced cheek teeth cingula, $\mathrm{P}^{4}$ with a short metacone.

TYPE MATERIAL.-Holotype: USNM 206273 (Emlong field no. E-225), cranium lacking rostrum and left jaw fragment; collected by Douglas Emlong, spring, 1964.

ETYMOLOGY.-The species is named in honor of Richard $\mathrm{H}$. Tedford who together with Edward D. Mitchell initially described specimens referred to this genus and recognized the significance of these fossils to pinniped evolution.

TYPE LOCALITY.-North of Seal Rock about 300 yds [275 m] south of the mouth of Beaver Creek, Lincoln County,
Oregon. Near NW corner Sec. 19, T. 12 S, R. 11 W, Yaquina

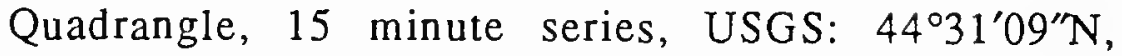
$124^{\circ} 04^{\prime} 40^{\prime \prime} \mathrm{W}$.

HORIZON.-According to Emlong's field notes this specimen was found "from drift concretion in the Yaquina Formation."

DESCRIPTION.-The cranium lacks most of the rostrum (Figure 16). The animal was an adult as evidenced by the degree of suture closure. Tables 2-4 list skull and tooth measurements.

The interorbital region is very narrow and small supraorbital ridges are on the anterolateral margins (Figure 16). The sagittal and lambdoidal crests are well developed. The supraoccipital shield is broad and low. The foramen magnum is wider than it is high, differing from the nearly circular condition in $E$. 

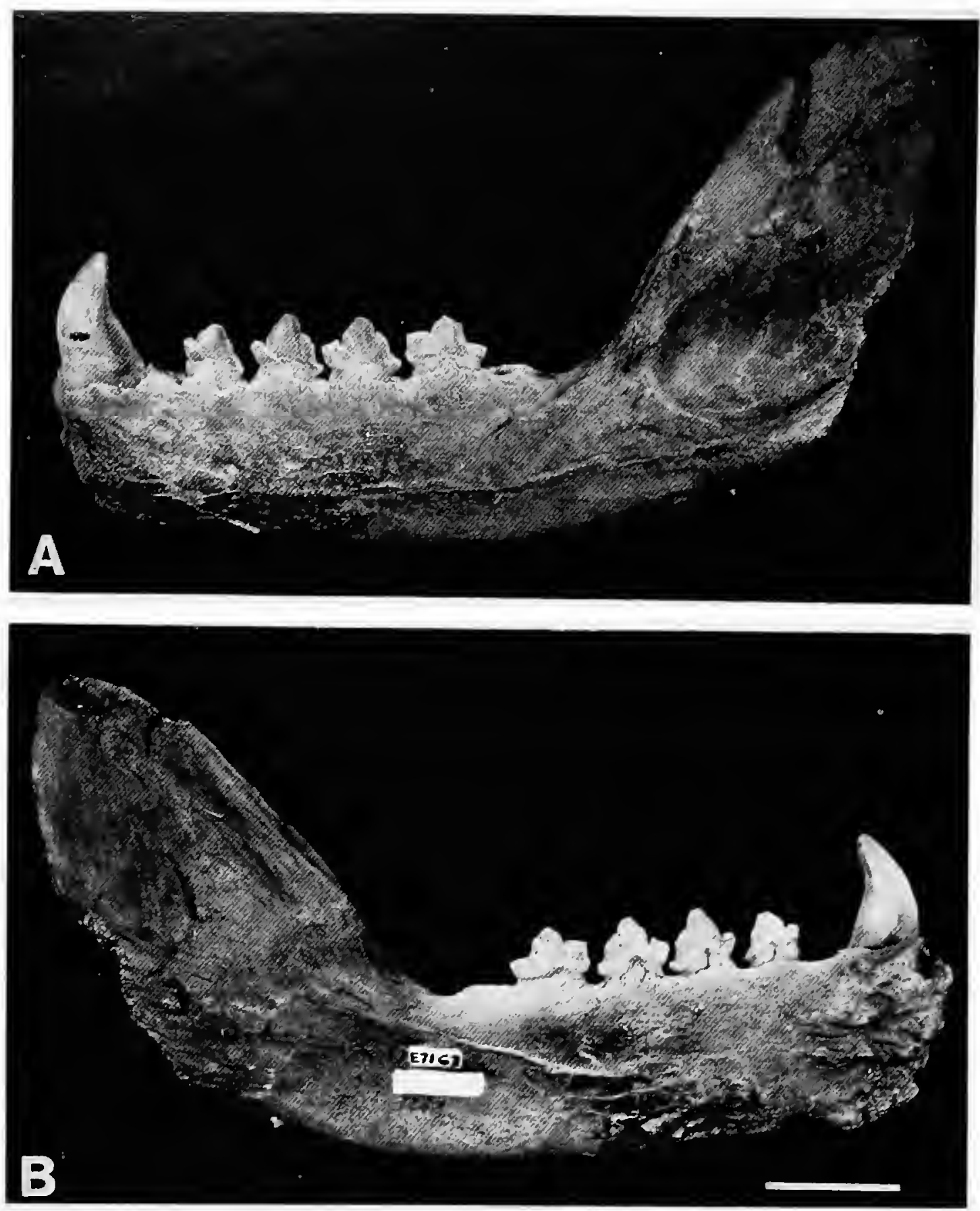

FIGURE 14.-Enaliarctos barnesi, new species, USNM 314295, holotype, left lower jaw: A, lateral view; B, medial view. (Scale $=2 \mathrm{~cm}$.)

emlongi. The condyloid foramen is deeply recessed within the foramen magnum.

No orbital vacuities are developed and there is no trace of a lacrimal foramen. A well-defined circular pit is present lateral to the infraorbital foramen for the inferior oblique muscles. The infraorbital foramen is ovoid and broader than it is high. The zygomatic arch is similar to that of $E$. mealsi (Mitchell and Tedford, 1973, fig. 6) but differs in being less bowed laterally and less arched dorsally. The posterior border of the arch joins the palate at the posterior root of $\mathrm{M}^{1}$. The squamosal and jugal contact one another in a splint-like arrangement.

The anterior palatine fossa and their associated sulci are prominent on either side of the palate and extend from $\mathrm{P}^{4}$ anteriorly. The palatine processes of the maxilla are developed as short, rounded processes of bone that extend a short distance behind $\mathrm{M}^{2}$.
The basioccipital is marked posteriorly by a pair of deep depressions, separated by a median crest, for the rectus capitis muscles. The presence of basioccipital tuberosities cannot be ascertained owing to incomplete preservation. Hypoglossal foramina are positioned at the posteromedial margin of the basioccipital.

The mastoid process is enlarged and knob-like (Figure 16). The smaller paroccipital process is joined to it by a very low, broad ridge. The paroccipital process differs from $E$. emlongi in being relatively larger and projecting further posteriorly. The fragmentary posterior carotid canal is adjacent to the enlarged jugular foramen.

Tympanic bullae are poorly preserved; the right bulla is entirely missing and the left bulla, already partially broken, was removed. The tympanic crest is similar to $E$. mealsi but differs from $E$. emlongi in its smaller size and shelf-like proportion 

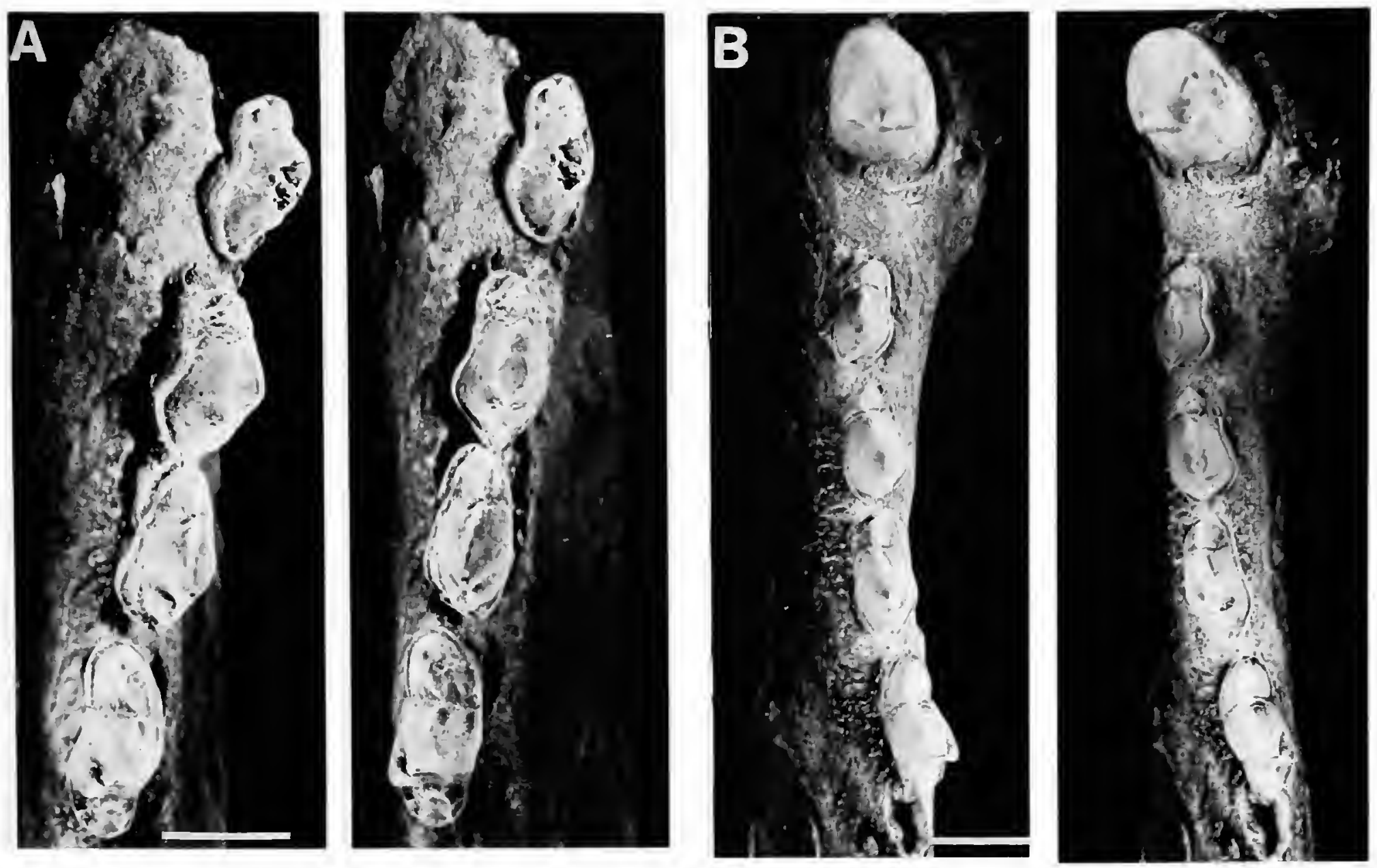

FIGURE 15.- Stereophotographs of lower dentition of Enaliarctos barnesi, new species, USNM 314295 , holotype: A, right $P_{2-4}, M_{1}: B$, left $C, P_{2-4}, M_{1}$. (Scale $=1 \mathrm{~cm}$.)

with only a slight projection into the tympanic cavity. Much of the posteromedial wall of the bulla is broken away. Beneath the remaining ledge of the bulla is the wall of the carotid canal.

The abraded surface of the tympanic cavity obscures much of the detail of this region. The promontorium is similar in size and morphology to $E$. emlongi. The round window is distinguishable as a posterolateral opening at the base of the promontorium. The fossa for the tensor tympani is a shallow, elliptical pit situated anterolateral and ventral to the promontorium. The epitympanic recess is largely filled with hard matrix.

The malleus and incus were recovered in poor condition. The malleus is small. The head is uninflated and lacks a deep concavity. Neither an anterior lamina nor anterior process were developed. The manubrium is relatively short and broad. The incus is also small and uninflated.

The holotype bears the posterior portion of the right and left $\mathrm{P}^{2}$, right $\mathrm{P}^{3}$, and left $\mathrm{P}^{4}$, and the alveoli of right $\mathrm{P}^{4}$, left and right $\mathrm{M}^{1}$, and left $\mathrm{M}^{2}$ (Figure 17). $\mathrm{P}^{2-3}$ consist of a large central paracone followed by a short crest-like metacone. The metacone is larger in $\mathrm{P}^{3}$. Lingual cingula are well developed. A principal difference between the anterior premolars of $E$. emlongi and $E$. tedfordi is the degree of development of the metacone. E. tedfordi is distinguished by having a large metacone.

$\mathrm{P}^{4}$ is three-rooted with a large conical paracone separated by a notch from a crest-like metacone (Figure 17). Wear facets are along the shearing surfaces of the paracone and metacone. The protocone is a broadly developed shelf centrally positioned. Wear has created an ovoid pit in the middle of the shelf.

As judged from the alveolus, $\mathrm{M}^{1}$ is double rooted with a small anterior root and a large posterior root. The alveolus for $\mathrm{M}^{2}$ is only preserved on the left side; although most of the labial portion is broken away it appears to have been relatively small.

Associated with the cranium was a fragment of the left jaw consisting of a portion of the ascending ramus including the coronoid process and condyle. The specimen is similar to $E$. emlongi and $E$. barnesi in having a relatively broad coronoid process.

\section{Enaliarctos mitchelli Barnes}

Figures $18-20$

EMENDED DIAGNOSIS OF SPECIES.-Distinguished from all other species of Enaliarctos by having a high narrow rostrum, ventral portion of zygoma flat with fossa, zygomatic arches lower on skull, high circular anterior narial opening, and $\mathrm{M}^{1}$ with reduced protocone. Distinguished from all other species except $E$. emlongi in having posterior portion of zygoma joining palate behind $\mathrm{M}^{1}$. Distinguished from $E$. barnesi and $E$. 

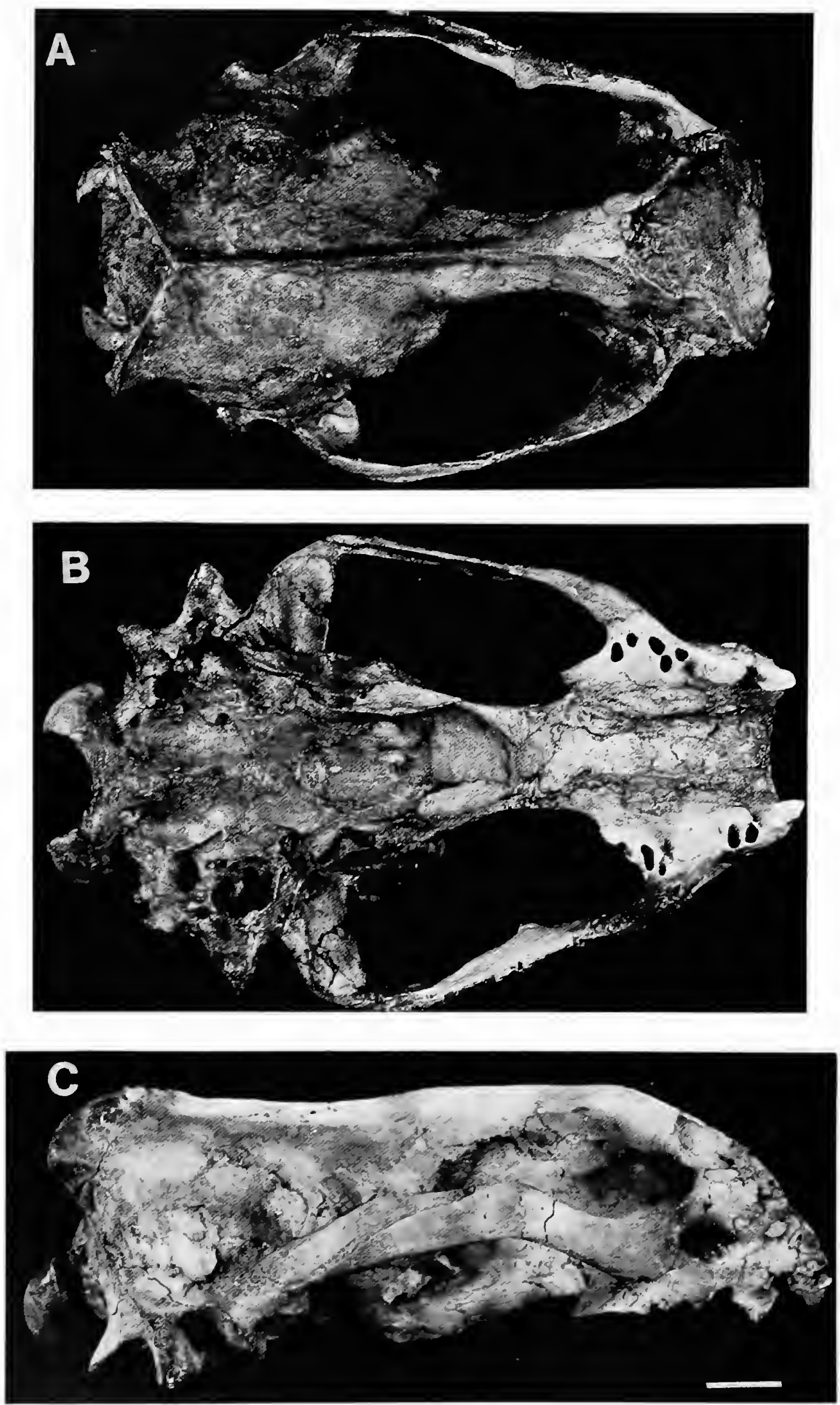

FIGURE 16.-Enaliarctos tedfordi, new species, USNM 206273, holotype, skull: A, dorsal view; B, ventral view; C, lateral view. (Scale $=2 \mathrm{~cm}$.) 

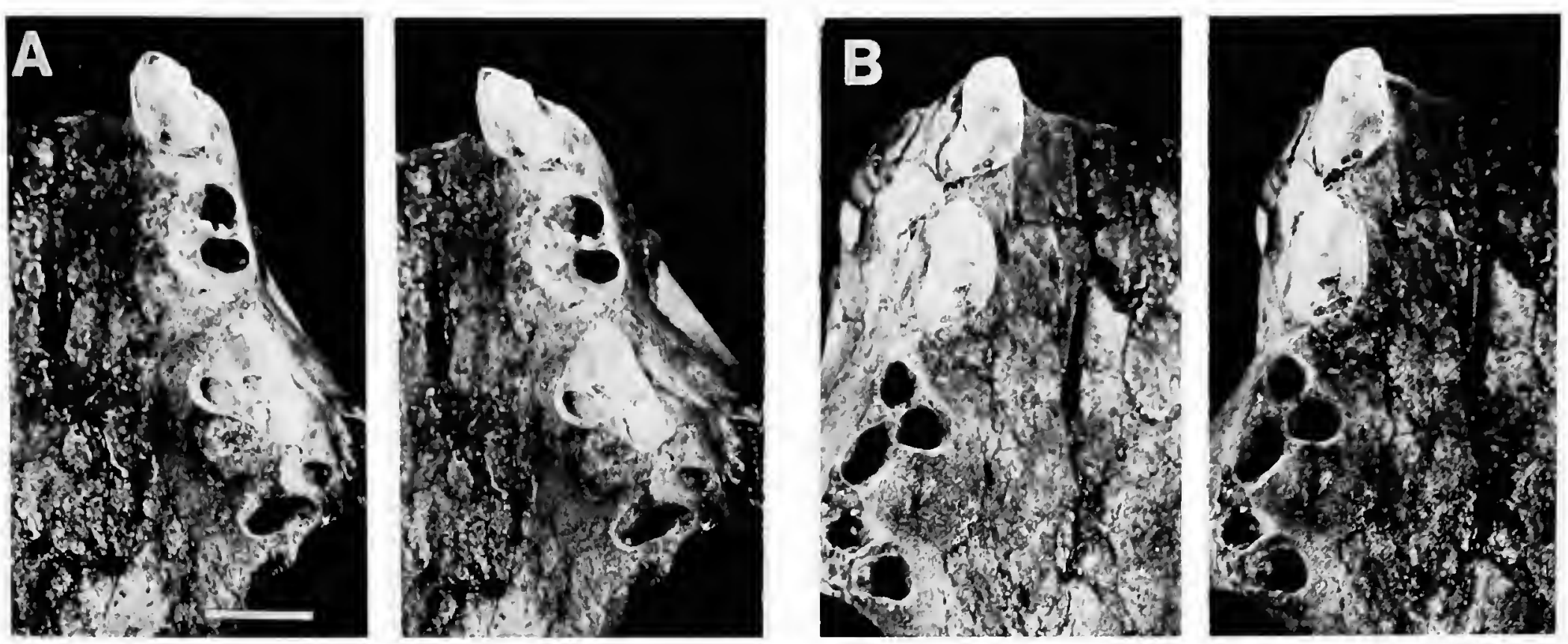

FIGURE 17.-Stereophotographs of palate and upper dentition of Enaliarctos tedfordi, new species, USNM 206273, holotype: A, left $P^{2}, P^{4} ; B$, right $P^{2-3}$. (Scale $=1 \mathrm{~cm}$.)

mealsi in having reduced cheek teeth cingula, $\mathrm{P}^{4}$ with a short metacone.

TYPE MATERIAL.-Holotype: UCMP 100391, anterior half of cranium.

Paratype: UCMP 80943, partial palate, bearing parts of both canines.

TYPE LOCALITIES AND HoRIZONS. - As described by Barnes (1979:12) the holotype was collected in loose rock but probably from the "upper fossiliferous, concretion-bearing bed" on the south face of Pyramid Hill; collected by Daryl P. Domning, 6 May 1972. The paratype is presumably from the same locality as the holotype; collected by J. Howard Hutchison, 18 May 1968.

REFERRED SPECIMEN._USNM 175637, nearly complete cranium missing anteriormost portion of rostrum, squamosals, and right wall of the braincase; collected in two parts by Douglas Emlong. According to Emlong's field notes the braincase (E-74-8) was collected in 1970 in float from the Nye Mudstone, about $1 / 3 \mathrm{mi}[530 \mathrm{~m}$ ] south of the mouth of Thiel Creek, Lincoln County, Oregon. NE corner Sec. 24, T. 12 S, R. $12 \mathrm{~W}$, Yaquina Quadrangle, 15 minute series, USGS: $44^{\circ} 33^{\prime} 28^{\prime \prime} \mathrm{N}, 124^{\circ} 04^{\prime} 18^{\prime \prime} \mathrm{W}$. Emlong collected the anterior half of the skull (E-597) in 1974 from near the same locality and recognized that it probably belonged to the braincase he had previously collected.

DESCRIPTION.-The specimen referred to E. mitchelli, USNM 175637, is a well-preserved cranium lacking squamosal portions of the zygomata (Figure 18). Much of the wall of the braincase on the right side is missing and the specimen has been prepared on that side exposing the floor of the braincase (Figure 19). The anteriormost portion of the snout is missing but the portion posterior to the incisive foramina, the canine roots, and a small portion of the left canine are preserved. Both the right and left $\mathrm{P}^{1}$ are represented by alveoli. The cheek teeth on the right side have been sheared off along their labial margins. $\mathrm{P}^{2-4}$ and $\mathrm{M}^{1}$ are well preserved on the left side and the alveoli of right $\mathrm{M}^{1}$ and right and left $\mathrm{M}^{2}$ are present. This specimen was an adult; all of the sutures except those bordering the nasals are fused.

The referred cranium of $E$. mitchelli is comparable in size to the holotype (Tables 2-3). The rostrum is deeper dorsoventrally. In anterior view, the narial opening is more nearly ovoid and not circular as in the holotype (Barnes, 1979, fig. 3). The nasals are relatively short. The nasolabialis fossa is pronounced and vertically oriented as in the holotype. A strong antorbital ridge is developed along the posterior rim of the fossa, which is continuous with a ridge that defines the anterior margin of the fossa (Figure 18).

The interorbital region is narrow. Supraorbital ridges are weakly developed. Both the sagittal and lambdoidal crests are heavily abraded. The braincase has squared anterolateral margins with well-marked oblique depressions on either side for the sylvian sulcus. The surface of the braincase is irregular and pitted by numerous small foramina. The occipital condyles are missing. A pair of deep fossae are positioned at the dorsolateral margins of the foramen magnum. The occipital shield is broad and low. It is slightly concave dorsally and it becomes convex above the foramen magnum. Within the foramen magnum is the condyloid foramen with a thin medial wall.

The zygomatic arch is more dorsally curved than in the holotype (Barnes, 1979, fig. 3) and the postorbital process of the jugal at its juncture with the skull is elevated higher above the toothrow (Figure 18). The ventral surface of the arch is nearly horizontal at its juncture with the skull and produced into a shallow fossa. The posterior border of the zygomatic arch joins the palate between $\mathrm{M}^{1}$ and $\mathrm{M}^{2}$.

The fusion of sutures in the orbital region makes it 

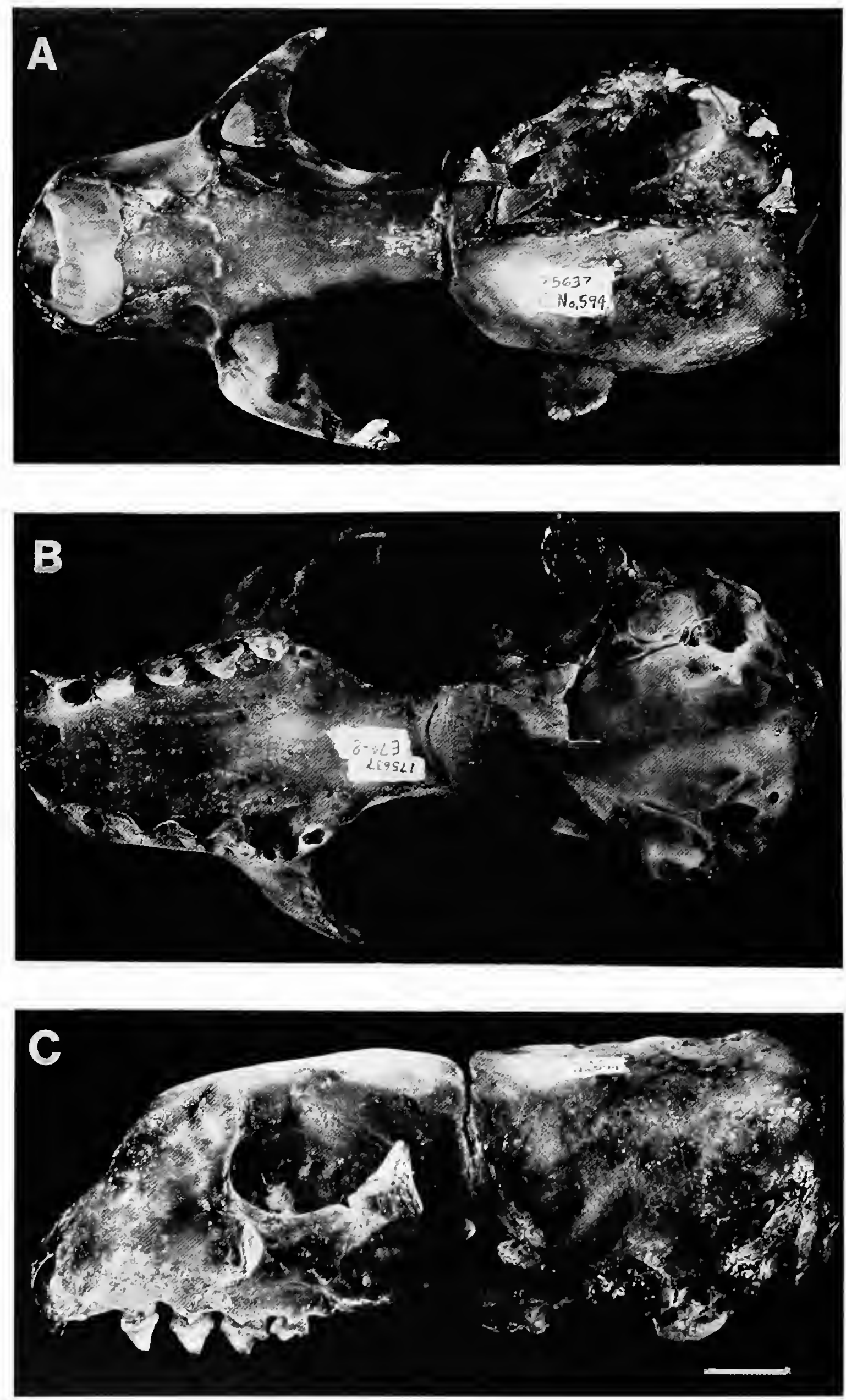

FIGURE 18.-Enaliarctos mitchelli, USNM 175637, referred specimen, skull: A, dorsal view; B, ventral view; C, lateral view. (Scale $=2 \mathrm{~cm}$.) 


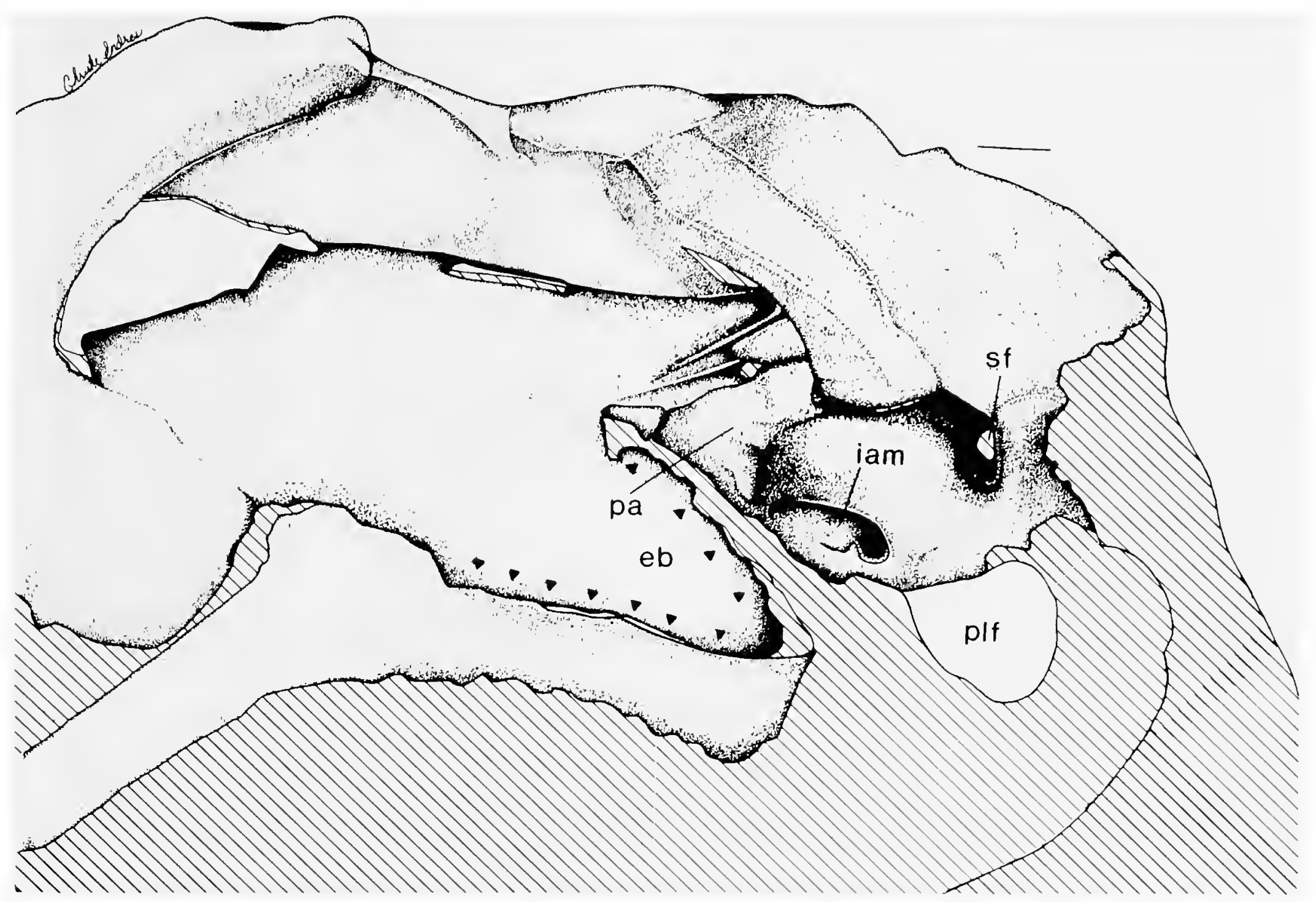

FIGURE 19.-Enaliarctos mitchelli, USNM 175637, referred specimen, dorsal view of floor of braincase. Cross hatched area is filled with matrix. Abbreviations: $\mathrm{eb}=$ embayment in basioccipital; iam = internal auditory meatus; $\mathrm{pa}=$ petrosal apex; $\mathrm{plf}$ = posterior lacerate foramen; $\mathrm{sf}=$ subarcuate fossa. (Scale is approximately $5 \mathrm{~mm}$.)

impossible to determine if a lacrimal bone was present. A small, circular lacrimal foramen is discernible. The orbital region is solid with no vacuities. The enlarged infraorbital foramen is roughly triangular and higher than it is wide. A pit for the inferior oblique muscle is positioned medial to the anterior rim of the infraorbital foramen. The large sphenopalatine foramen is situated dorsal to the termination of the palatine process of the maxilla. Anteroventral to it is a small posterior palatine foramen. The circular ethmoidal foramina lies $11 \mathrm{~mm}$ from the optic foramina. The large optic foramina is located below the interorbital septum and dorsal to the braincase. The anterior lacerate foramina emerge from the braincase lateral and posterior to the optic foramina, separated from the alisphenoid by a bony vertical septum.

The incisive foramina are similar in shape and orientation to the holotype. A groove runs down the middle of the palate surrounded on either side by a pair of anterior palatine foramina with associated sulci originating medial to $\mathrm{P}^{4}$ and terminating medial to $\mathrm{P}^{2}$. USNM 175637 differs from the holotype and paratype of E. mitchelli (Barnes, 1979, fig. 3) in having several smaller posterior foramina in addition to the anterior pair. A small central pair with associated shallow furrows is located posterolateral to the anterior pair, and posteromedial to the central pair are several randomly distributed very small foramina. The palatine process of the maxilla is a rounded projection that terminates a short distance behind the $\mathrm{M}^{2}$ alveolus. The palate has a $U$-shaped smooth margin.

The palatine and alisphenoid are inflated struts between the palate and the braincase. The delicate pterygoid hamulus is preserved on the left side of USNM 175637.

The basicranial region is similar to that of other species of the genus. A deep trough formed largely of the basisphenoid is separated by a $V$-shaped ridge from the basioccipital, which is marked by a pair of depressions for the rectus capitis muscles. Lateral to these depressions are a pair of large tuberosities that are further discussed below.

Tympanic bullae are flask-shaped and medially inflated (Figure 18). Anterolaterally the bulla is fused to the postglenoid process. The paroccipital and mastoid processes are broken away near the base of the skull. A short flange of bone separates the opening for the eustachian tube from the median lacerate foramen. The posterior carotid foramen lies slightly anterior to 

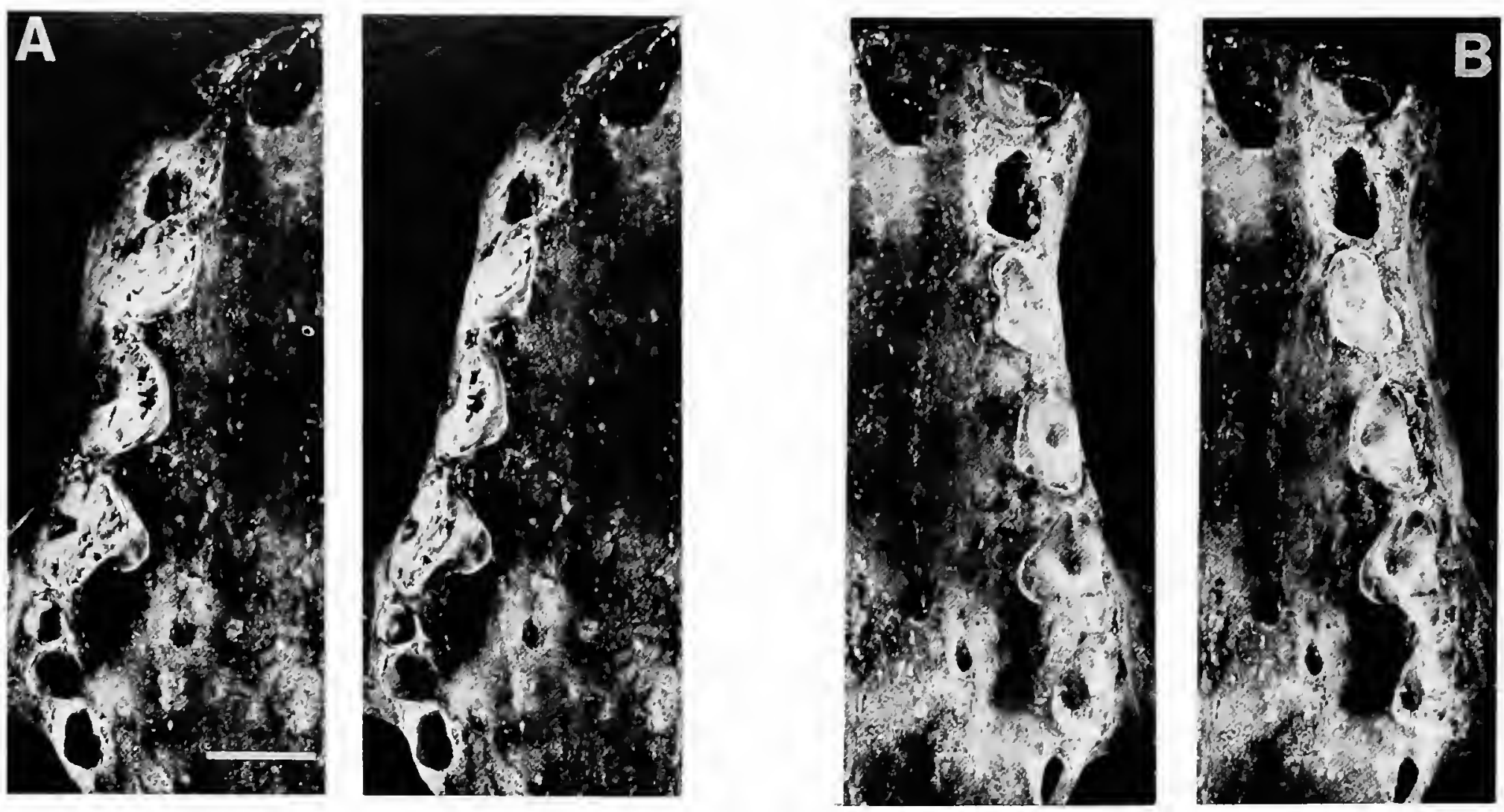

FIGURE 20.-Stereophotographs of palate and upper dentition of Enaliarctos mitchelli, USNM 175637, referred specimen: A, right $\mathrm{P}^{2-4} ; \mathrm{B}$, left $\mathrm{P}^{2}-\mathrm{M}^{1}$. (Scale $=1 \mathrm{~cm}$.)

the large opening for the posterior lacerate foramen and separated from it by a bony bridge. As preserved on the right side, the circular stylomastoid foramen lies in a deep pit. The pit for the tensor tympani lies posterior to the stylomastoid foramen, separated from it by a narrow crest of bone.

Preparation of the dorsal surface of the braincase provides evidence of an excavation in the lateral edge of the basioccipital (Figure 19). On the ventral surface of the skull these excavations appear as large tuberosities that are deflected medially at their posterior termination. As noted previously, these tuberosities may indicate the presence of the basioccipital embayment and presumed loop of the internal carotid artery. Anterior to the cochlea the petrosal apex is sharply pointed. The subarcuate fossa is deep and circular. The internal acoustic meatus is a relatively large, flattened single opening.

The cheek teeth of E. mitchelli are represented in USNM 175637, which preserves $\mathrm{P}^{2-4}$ and $\mathrm{M}^{1}$ (Figure 20). Previously no cheek teeth were known for this species. Only a small fragment of the left canine is preserved. The alveolus for $\mathrm{P}^{1}$ is positioned directly behind the canine and indicates this tooth had a relatively large single root.

$\mathrm{P}^{2-3}$ are double rooted, high crowned, and posteromedially broad. Well-developed lingual cingula are present extending onto the labial side of the tooth at the anterior and posterior tooth margins. The anterior premolars consist of a single large paracone followed by a very small metacone, faintly indicated on the posterior slope of the paracone. The degree of development of the metacone resembles that in $E$. mealsi (Barnes, 1979, fig. 2a). Wear is apparent along the posteromedial margin of $\mathrm{P}^{3}$.
$\mathrm{P}^{4}$ is large relative to $\mathrm{M}^{1}$, three-rooted, and encircled by a well-defined cingulum that is especially prominent lingually. The paracone is much larger than the metacone and separated from it by a sharp notch (Figure 20). The protocone is shelf-like and centrally positioned. A large wear facet extends from the posterior protocone shelf across the posterior surface of the paracone and metacone. As in the holotype, the three roots of $\mathrm{P}^{4}$ are positioned closer together than in E. mealsi (Barnes, 1979, fig. 5). A deep embrasure pit in the palate is developed between $\mathrm{P}^{4}$ and $\mathrm{M}^{1}$.

$\mathrm{M}^{1}$ is double rooted. The crown is elongate with a long, low paracone separated from the labial tooth margin by the parastyle. A wear facet is present on the anteromedial margin of the parastyle. The paracone is separated from the small, conical metacone by a shallow notch. The protocone is developed as a low posterolingual shelf.

$M^{2}$, as judged from the alveolus, was single rooted and differs from the holotype in being relatively larger.

COMMENTS. - Of the characters used by Barnes (1979) to distinguish $E$. mitchelli from $E$. mealsi in his original description, most are diagnostic: narrow, high rostrum; high, anterior narial opening that is nearly circular in anterior view; zygomatic arches relatively lower on skull and not greatly arched at midpoint; and ventral surface of zygomatic arch ventral to the infraorbital foramen more nearly horizontal and not as steeply inclined anteriorly. The narrow interorbital region and the single paired posterior palatine foramina (probably homologous with the anterior palatine foramina $=$ anterior opening of the palatine canal) of $E$. mitchelli cited by Barnes as diagnostic features were here determined not useful to distinguish Enaliarctos species. 


\section{Interspecific Affinities of Enaliarctos*}

Currently five species of the genus Enaliarctos* are recognized: E. mealsi, E. mitchelli, E. barnesi, E. tedfordi, and E. emlongi. Assignment of these species to Enaliarctos was based on a phylogenetic analysis of 16 cranial and dental characters (Table 6). Two equally parsimonious trees were found by the branch and bound option of PAUP (Phylogenetic Analysis Using Parsimony) version 3.0 (Swofford, 1989) with a branch length of 20 and a consistency index (C.I.) of .900 . The strict consenus tree is shown in Figure 21. For all characters it was possible to use the most proximate outgroup, the Ursidae. Primitive ursids examined included Cephalogale, Amphicynodon, Pachycynodon, and Allocyon. Cephalogale has been previously allocated to the Hemicyoninae (Mitchell and Tedford, 1973) and Amphicynodon and Pachycynodon have been included within the paraphyletic Amphicynodontinae (Flynn et al., 1988). Recognition of Allocyon as an ursid follows the suggestion of Tedford (pers. comm.).

Enaliarclos mealsi* is here identified as a metaspecies based on its lack of diagnostic attributes. A number of features were listed by Barnes (1979) in his revised diagnosis of the species. Of these, most are symplesiomorphies. The remaining species of Enaliarctos* comprise two internested monophyletic groups (Figure 21). The first group is comprised of the recent common ancestor of $E$. barnesi and the Unnamed Taxon that includes $E$. tedfordi, E. emlongi, and E. mitchelli. A single synapomorphy unites this group: short nasal bones (SYNAPOMORPHY 12). Insofar as long nasal bones are present in the outgroup, I regard this condition as ancestral in Enaliarctos, with its subsequent reversal in E. emlongi. Enaliarctos barnesi is diagnosed on the basis of two unequivocal characters and one equivocal character briefly discussed here.

14. $P^{3}$ lingual shelf. A lingual shelf is absent among primitive ursids. Among Enaliarclos species only E. barnesi and $E$. emlongi have lingual shelves developed; $E$. emlong $i$ is distinguished by having a more broadly developed shelf.

15. Short lower cheek tooth row. The lower cheek teeth in $E$. barnesi are arranged very close to one another with no diastemata, and the length of tooth row is short in comparison to that of E. emlongi and primitive ursids (Table 4).

One other character was equivocally assigned to this level: rounded palatine processes (SYNA POMORPHY 1). The spur-like condition of these processes in $E$. barnesi are interpreted as a reversal to the primitive condition based on outgroup comparsion.

The second monophyletic Enaliarctos clade is defined as the recent common ancestor of the Unnamed Taxon that includes $E$. tedfordi, E. emlongi, and E. mitchelli. As described below two unequivocal synapomorphies diagnose this group with four additional characters treated as ambiguous.

4. Reduced cheek teeth cingula. Well-developed labial and lingual cingula surrounding the cheek teeth have been identified in ursids (e.g., Cephalogale de Beaumont, 1965), $E$. mealsi (Mitchell and Tedford, 1973), and E. barnesi. In contrast, the cingula are reduced in E. tedfordi, E. emlongi, and E. mitchelli.

6. $P^{4}$ metacone short. Although de Beamont (1965) describes the metacone blade in Cephalogale minor as short, it is in fact relatively long (pers. observ.) and comparable in length to that of E. mealsi (Mitchell and Tedford, 1973, fig. 15) and $E$. barnesi. In contrast, E. tedfordi, E. emlongi, and E. mitchelli are all characterized by having a short metacone on the upper camassial.

Four additional characters were identified by PAUP as potential synapomorphies at this level, but with equally parsimonious explanations also available. Because three of these (SYNAPOMORPHIES $7,8,10$ ) were scored as missing data (?) among two of the three species, I treat them as apomorphies at the minimum levels at which observation confirms their distribution (see Figure 21). Another character, $\mathrm{P}_{3-4}$ with large paraconids well separated from protoconid (SYNAPOMORPHY 16) is equivocally assigned to this clade as a reversal.

Within this group, a sister group relationship between $E$. emlongi and $E$. mitchelli is supported by one synapomorphy.

3. Posterior portion of zygoma joins palate posterior to $M^{I}$. This is another feature originally used by Bames (1979) to distinguish $E$. mitchelli from $E$. mealsi. As determined by this study, the primitive condition in which the zygoma joins the palate between the roots of $\mathrm{M}^{1}$ is seen in $E$. mealsi and $E$. ledfordi as well as primitive ursids.

Characters that distinguish E. mitchelli from E. emlongi include the following.

2. Ventral portion of zygoma flat with fossa. This feature was originally used by Barnes (1979) to distinguish $E$. mitchelli from $E$. mealsi. As observed by Barnes in $E$. mealsi, the ventral surface of the zygomatic arch beneath the infraorbital foramen is inclined anterodorsally and lacks a fossa. Although the zygomatic arch is not completely preserved among primitive ursids (e.g., Cephalogale de Beaumont, 1965, fig 24; Allocyon Merriam, 1930, fig. 1) they possess inclined zygoma. Based on additional material of Enaliarctos described herein, I regard the flat condition of the zygoma as diagnostic at this level.

13. Zygomatic arches lower on skull. As observed by Barnes (1979:12, figs. 18a,b) in E. mealsi the zygomatic arch has a continuous dorsal curvature in lateral view in contrast to E. mitchelli, in which the arch "makes a more acute angle in the horizontal plane where it joins the skull. Consequently the postorbital process of the jugal is lower on the skull in $E$. mitchelli." The distribution of this feature among primitive ursids indicates that the flat, low condition of the arch is derived.

Among species of Enaliarctos* several dental trends can be noted. The presence of cheek teeth with sectorial features, namely large, blade-like cusps, the lingual position of enlarged protocone shelves, the elevation of molar trigonids, and a long talonid, exemplified by E. barnesi and E. mealsi*, represent the primitive pinniped morphotype. This conclusion stems from recognition of the distribution of "sectorial" dental features 
TABLE 6.-Distribution of cranial and dental features among Enaliarctos species and the outgroup Ursidae. (Symbols: 0 = primitive; $1-2$ = derived states; ? = not known.)

\begin{tabular}{|c|c|c|c|c|c|c|}
\hline & 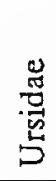 & 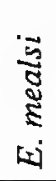 & 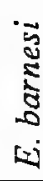 & 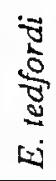 & 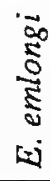 & 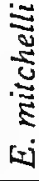 \\
\hline 1. Rounded palatine processes & 0 & 1 & 0 & 1 & 1 & 1 \\
\hline 2. Ventral portion zygoma flat with fossa & 0 & 0 & 0 & 0 & 0 & 1 \\
\hline 3. Posterior portion of zygoma joins palate posterior to $\mathrm{M}^{1}$ & 0 & 0 & $?$ & 0 & 1 & 1 \\
\hline 4. Reduced cheek teeth cingula & 0 & 0 & 0 & 1 & 1 & 1 \\
\hline 5. $\mathrm{P}^{2-3}$ metacone large, crest-like & 0 & 0 & 0 & 1 & 2 & 0 \\
\hline 6. $\mathrm{P}^{4}$ metacone short & 0 & 0 & 0 & 1 & 1 & 1 \\
\hline 7. $\mathrm{P}_{3-4}$ metaconid small & 0 & 0 & 0 & $?$ & 1 & $?$ \\
\hline 8. $\mathrm{M}_{1}$, metaconid very reduced, close to protoconid & 0 & 0 & 0 & $?$ & 1 & $?$ \\
\hline 9. High, narrow rostrum & 0 & 0 & 0 & 0 & 0 & 1 \\
\hline 10. $\mathrm{M}^{1}$ very reduced protocone & 0 & 0 & 0 & $?$ & $?$ & 1 \\
\hline 11. High, circular anterior narial opening & 0 & 0 & $?$ & $?$ & 0 & 1 \\
\hline 12. Short nasal bones & 0 & 0 & 1 & $?$ & 0 & 1 \\
\hline 13. Zygomatic arches lower on skull & 0 & 0 & $?$ & 0 & 0 & 1 \\
\hline 14. $\mathrm{P}^{3}$ lingual shelf & 0 & 0 & 1 & 0 & 2 & 0 \\
\hline 15. Short lower cheek tooth row & 0 & $?$ & 1 & $?$ & 0 & $?$ \\
\hline 16. $\mathrm{P}_{3-4}$ large paraconids, well separated from protoconids & 0 & 1 & 1 & $?$ & 0 & $?$ \\
\hline
\end{tabular}

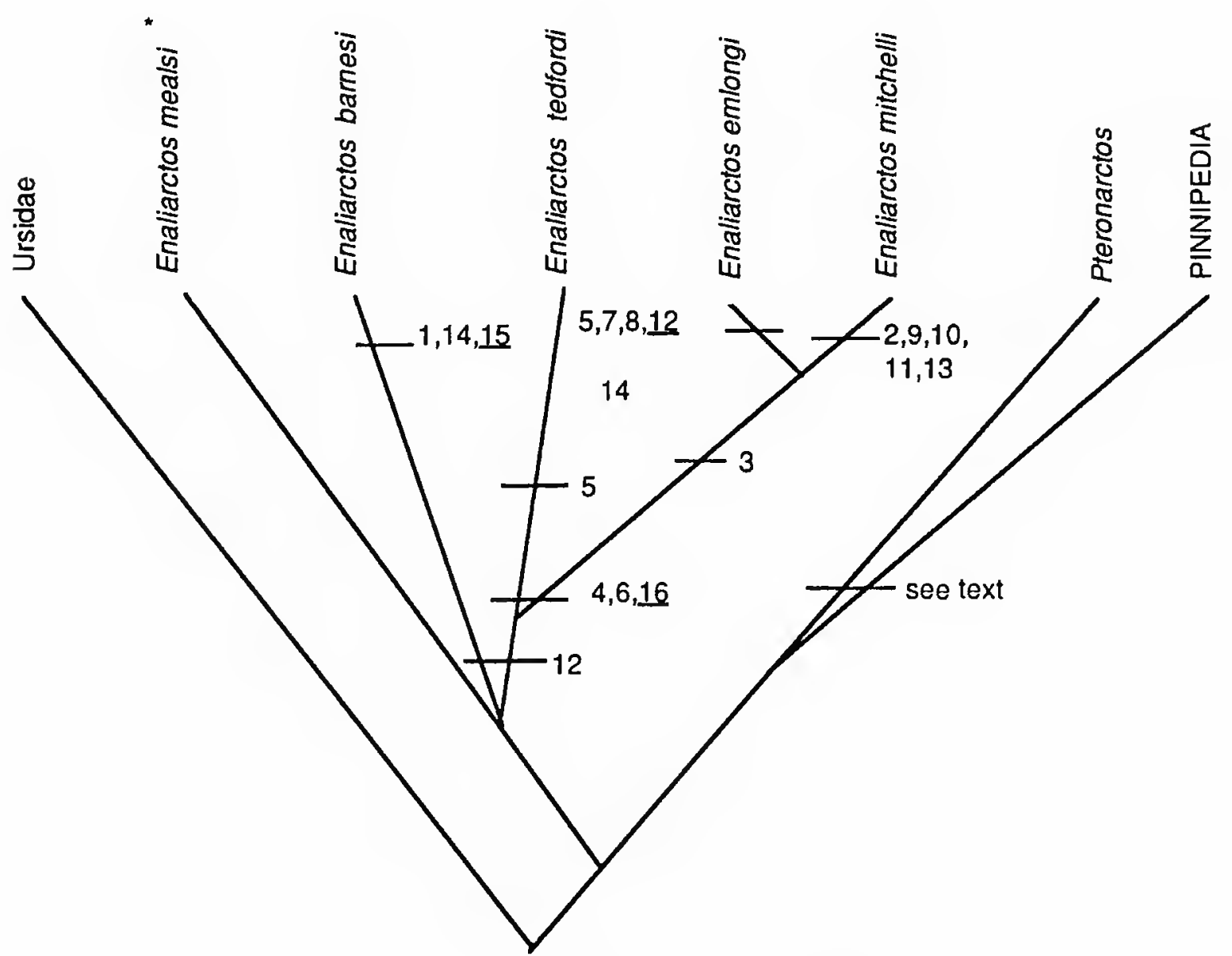

FIGURE 21.-Phylogeny of Enaliarctos species. Numbers refer to derived characters listed in Table 6 and discussed in text. 
among primitive ursids and amphicyonids (see following section). All other species of the genus possess cheek teeth with reduced cingula and a reduced metaconid on $M_{1}$ suggesting a decreased carnassial function of the cheek teeth. A continuation of the trend toward loss of "fissiped-like" carnassials distinguished by taxa having a short metacone on $\mathrm{P}^{4}$ is seen among members of Group 2: E. tedfordi, E. emlongi, and E. mitchelli.

\section{Higher Level Relationships of Enaliarctos* and "Enaliarctids"}

Forty-two binary and 10 multistate characters among pinnipedimorphs (Enaliarctos, Pteronarctos, Otariidae, Odobenidae, Allodesmus, Desmatophoca, Pinnarctidion, and Phocidae) were scored on a taxon-character matrix (Table 7). All multistate characters were entered as unordered, and missing data were entered as?. The branch and bound option of PAUP (Swofford, 1989) resulted in a single most parsimonious tree with a branch length of 75 and a consistency index (C.I.) of .840 (Figure 22).

As previously mentioned, the Ursidae was employed as the first outgroup. Following the suggestion of Maddison et al. (1984) a second outgroup was also employed, the extinct Amphicyonidae. Flynn et al. (1988) provided three alternate hypotheses for relationships of the Amphicyonidae: (1) amphicyonids as arctoids (relationships unresolved among arctoids), (2) amphicyonids as sister group of other arctoids, or (3) amphicyonids as sister taxon to the Ursidae. My analysis supports the view that the Amphicyonidae are the sister taxon to the Ursidae. Retention of the excavated basioccipital and presumed loop of the internal carotid artery in Enaliarctos supports consideration of this feature as a synapomorphy uniting the Ursida clade (including Amphicyonidae, Ursidae, and Pinnipedimorpha).

Flynn et al., (1988) briefly reviewed possible relationships of pinnipeds to other arctoids. One view holds that pinnipeds are the sister group of ursids while in the second arrangement pinnipeds are part of a multichotomy with other arctoid families. Their support for an ursid-pinniped alliance is based on two dental synapomorphies: shelf-like anteromedially placed $\mathrm{P}^{4}$ protocone and a narrow $\mathrm{M}^{1}$ with longitudinally elongated protocone. In addition, Wyss (1987) noted that pinnipeds and ursids are unique among carnivorans in lacking a muscular process on the malleus. As I have indicated elsewhere (Berta et al., 1989; Berta and Ray, 1990) to the list above may be added the following postcranial characters: knob-like acromion process of the scapula and ulna with a robust olecranon process. Thus, considerable evidence supports pinnipeds as having shared a most recent common ancestry with terrestrial arctoids, with ursids considered as the most likely sister group.

Enaliarctos* is recognized as the sister taxon of all other pinnipeds as originally proposed by Wyss (1987). The Pinnipedimorpha clade (Enaliarctos plus all other pinnipeds)
(Figure 22, node 1) can be distinguished from their closest relatives, the Ursidae, on the basis of 15 unequivocal characters and 5 equivocal characters (Table 7) discussed below.

1. Palatine process of maxilla extends behind last molar. The configuration of the palatal portion of the maxilla differs among pinnipedimorphs and ursids. In ursids the maxilla terminates at or slightly behind the last molar. In Enaliarctos and other pinnipeds the palatine process of the maxilla extends behind the last molar.

4. Large infraorbital foramen. Ursids and amphicyonids possess a small, slit-like infraorbital foramen. In pinnipedimorphs the infraorbital foramen is large.

5. Anterior palatine foramina anterior of maxillary-palatine suture. In ursids and most other terrestrial carnivorans the anterior palatine foramina are on the suture as observed by Wyss (1988b:30). A distinctive feature of pinnipedimorphs is the anterior position of the anterior palatine foramina relative to the maxillary-palatine suture.

7. Supraorbital processes very reduced-absent or large and shelf-like. As noted by Wyss (1987) the absence of large supraorbital processes may be primitive for pinnipeds or lost independently in Enaliarctos and "phocoids." Although I concur with Wyss that the absence of large supraorbital processes is the derived condition, I regard the condition of the supraorbital processes in Enaliarctos and phocoids differently. The supraorbital processes in Enaliarctos though very reduced are still consistently present as ridges or protuberances. In contrast, among odobenids, phocoids, and Allodesmus the processes are completely lacking.

8. Foramen rotundum merged with anterior lacerate foramen. The primitive condition in which the foramen rotundum is separate from the anterior lacerate foramen is seen in ursids and amphicyonids, as well as the "enaliarctid" Pinnarctidion. As noted by Barnes (1979:24) in Enaliarctos, otariids, and odobenids the foramen rotundum is merged with the anterior lacerate foramen. As discerned in the present study, the derived condition is more broadly distributed among other pinnipeds including phocids.

10. Large round window. All pinnipeds including Enaliarctos share a large round window (Wyss, 1987).

12. Epitympanic recess large. As noted by Mitchell and Tedford (1973) the epitympanic recess in Enaliarctos mealsi was large relative to the size of the middle ear cavity in comparison to Cephalogale. Wyss (1987) recognized this feature as a synapomorphy uniting all pinnipeds.

13. Postglenoid foramen vestigial-absent. In Cephalogale a large postglenoid foramen is present (Mitchell and Tedford, 1973). The postglenoid foramen is, in contrast, small or absent in pinnipedimorphs.

14. Jugular foramen greatly enlarged. The jugular foramen (= posterior lacerate) is enlarged in all pinnipeds including Enaliarctos as noted by Wyss (1987).

15. Enlarged auditory ossicles. As is true for other pinnipeds, the malleus and incus of Enaliarctos are relatively 
TABLE 7.-Distribution of cranial and dental features discussed in text. (Symbols: $0=$ primitive state; $1-2=$ derived states; ? = not known.)

1. Posterior extension of palatine process of maxilla

2. Nasolabialis fossa absent

3. Maxilla makes a significant contribution to orbital wall

4. Large infraorbital foramen

5. Anterior palatine foramina anterior of maxillary-palatine suture

6. Lacrimal fuses early to maxilla, greatly reduced or absent; dœes not contact jugal

7. Supraorbital processes reduced-absent or large and shelf-like

8. Foramen rotundum merged with anterior lacerate foramen

9. Mastoid process distant to paroccipital process

10. Large round window

11. Enlarged basal whorl of scala tympani

12. Epitympanic recess large

13. Postglenoid foramen vestigial-absent

14. Jugular foramen greatly enlarged

15. Enlarged auditory ossicles

16. Middle ear cavity and EAM lined with distensible cavernous tissue

17. Pseudosylvian sulcus strongly developed

18. Deciduous dentition reduced

19. $\mathrm{M}^{1-2}$ small-subequal relative to premolars

20. $M_{1}$ entoconid reduced-absent

21. $M_{1}$ hypoconid reduced-absent

22. $\mathrm{M}_{3}$ absent

23. Nasal processes of premaxilla, prominent protrude above alveolar margin

24. Canal for cochlear aqueduct merged with round window

25. Paroccipital process enlarged

26. $\mathrm{P}^{4}$, two-roots-single rooted

27. $\mathrm{M}^{1}$, two-roots-single rooted

28. $\mathrm{M}^{1-2}$ cingulum reduced-absent

29. $M_{1-2}$ trigonid suppressed

30. $\mathrm{M}_{1}$ metaconid greatly reduced-absent

31. $\mathrm{M}_{2}$ absent

32. Fossa muscularis absent

33. Large orbital vacuities present

34. Embrasure pit between $\mathrm{P}^{4}-\mathrm{M}^{1}$, shallow-absent

35. Pit for tensor tympani reduced-absent

36. Processus gracilis and anterior lamina of malleus reduced

37. $\mathrm{P}^{4}$ enlarged protocone shelf absent

38. Narrow contact between nasals and premaxilla

39. Ascending process of premaxilla-maxilla dips into nasal aperture

40. Canals for CN VII and VIII widely separate

41. Auditory bulla underlaps basioccipital

42. Petrosal visible through posterior lacerate foramen

43. Caudal entotympanic inflated

44. Basioccipital short, broad, widened posteriorly

45. Reduced coronoid process

46. $I^{3}$ caniniform with circular cross-section

47. $I^{3}$ lingual cingulum absent

48. Nasals terminate posterior to frontal-maxillary contact

49. Posteriorly wide palate

50. Squamosal-jugal, mortised contact

51. Flange below ascending ramus of mandible

52. Lower premolars with large paraconids

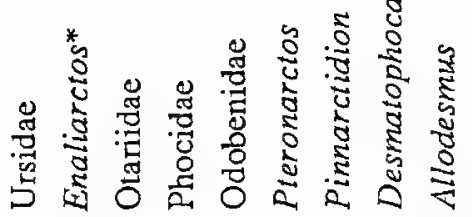

$\begin{array}{lllllllll}0 & 1 & 1 & 0 & 1 & 1 & 2 & 2 & 2\end{array}$

$\begin{array}{lllllllll}0 & 0 & 1 & 1 & 1 & 0 & 0 & 1 & 1\end{array}$

$\begin{array}{lllllllll}0 & ? & 1 & 1 & 1 & 1 & 1 & 1 & 1\end{array}$

$\begin{array}{lllllllll}0 & 1 & 1 & 1 & 1 & 1 & 1 & 1 & 1\end{array}$

$\begin{array}{lllllllll}0 & 1 & 1 & 1 & 1 & 1 & 1 & 1 & 1\end{array}$

$\begin{array}{lllllllll}0 & ? & 1 & 1 & 1 & 1 & 1 & 1 & 1\end{array}$

$\begin{array}{lllllllll}0 & 1 & 3 & 2 & 2 & 1 & 1 & 1 & 1\end{array}$

$\begin{array}{lllllllll}0 & 1 & 1 & 1 & 1 & 1 & 0 & 0 & 0\end{array}$

$\begin{array}{lllllllll}0 & 0 & 0 & 1 & 0 & 0 & 1 & 1 & 1\end{array}$

$\begin{array}{lllllllll}0 & 1 & 1 & 1 & 1 & 1 & ? & 1 & 1\end{array}$

$\begin{array}{lllllllll}0 & \text { ? } & 1 & 1 & 1 & \text { ? } & \text { ? } & 1 & 1\end{array}$

$\begin{array}{lllllllll}0 & 1 & 1 & 1 & 1 & 1 & 1 & 1 & 1\end{array}$

$\begin{array}{lllllllll}0 & 1 & 1 & 1 & 1 & 1 & 1 & 1 & 1\end{array}$

$\begin{array}{lllllllll}0 & 1 & 1 & 1 & 1 & 1 & 1 & 1 & 1\end{array}$

$\begin{array}{lllllllll}0 & 1 & 1 & 1 & 1 & 1 & \text { ? } & \text { ? } & 1\end{array}$

$\begin{array}{lllllllll}0 & \text { ? } & 1 & 1 & 1 & \text { ? } & \text { ? } & \text { ? } & \text { ? }\end{array}$

$\begin{array}{lllllllll}0 & 1 & 0 & 0 & 0 & 1 & 0 & 0 & 0\end{array}$

$\begin{array}{lllllllll}0 & \text { ? } & 1 & 1 & 1 & \text { ? } & \text { ? } & \text { ? } & \text { ? }\end{array}$

$\begin{array}{lllllllll}0 & 1 & 1 & 1 & 1 & ? & ? & 1 & 1\end{array}$

$\begin{array}{lllllllll}0 & 1 & 2 & 2 & 2 & \text { ? } & \text { ? } & 2 & 2\end{array}$

$\begin{array}{lllllllll}0 & 1 & 2 & 2 & 2 & \text { ? } & \text { ? } & 2 & 2\end{array}$

$\begin{array}{lllllllll}0 & 1 & 1 & 1 & 1 & 1 & ? & 1 & 1\end{array}$

$\begin{array}{lllllllll}0 & 0 & 1 & 0 & 1 & 1 & \text { ? } & 0 & 0\end{array}$

$\begin{array}{llllllllll}0 & 0 & 0 & 1 & 1 & \text { ? } & \text { ? } & \text { ? }\end{array}$

$\begin{array}{lllllllll}0 & 0 & 0 & 1 & 0 & 1 & 1 & 1 & 1\end{array}$

$\begin{array}{lllllllll}0 & 0 & 1 & 1 & 1 & 1 & \text { ? } & 1 & 2\end{array}$

$\begin{array}{lllllllll}0 & 0 & 1 & 1 & 1 & 1 & 0 & 2 & 2\end{array}$

$\begin{array}{lllllllll}0 & 1 & 1 & 1 & 1 & 1 & ? & 1 & 1\end{array}$

$\begin{array}{lllllllll}0 & 0 & 1 & 1 & 1 & \text { ? } & \text { ? } & 1 & 1\end{array}$

$\begin{array}{lllllllll}0 & 0 & 1 & 1 & 1 & ? & \text { ? } & 1 & 1\end{array}$

$\begin{array}{lllllllll}0 & 0 & 1 & 1 & 1 & 0 & \text { ? } & 1 & 1\end{array}$

$\begin{array}{lllllllll}0 & 0 & 1 & 1 & 1 & 0 & 1 & 1 & 1\end{array}$

$\begin{array}{lllllllll}0 & 0 & 1 & 1 & 1 & 0 & 0 & 0 & 1\end{array}$

$\begin{array}{lllllllll}0 & 0 & 1 & 1 & 1 & 1 & 1 & 1 & 1\end{array}$

$\begin{array}{lllllllll}0 & 0 & 1 & 1 & 1 & 0 & 1 & 1 & 1\end{array}$

$\begin{array}{lllllllll}0 & 0 & 1 & 1 & 1 & 1 & \text { ? } & \text { ? } & \text { ? }\end{array}$

$\begin{array}{lllllllll}0 & 0 & 1 & 0 & 1 & 0 & 0 & 1 & 1\end{array}$

$\begin{array}{lllllllll}0 & 0 & 0 & 1 & 1 & 0 & ? & 1 & 1\end{array}$

$\begin{array}{lllllllll}0 & 0 & 0 & 1 & 0 & 0 & ? & 1 & 1\end{array}$

$\begin{array}{lllllllll}0 & 0 & 0 & 2 & 1 & ? & 2 & 2 & 2\end{array}$

$\begin{array}{lllllllll}0 & 0 & 0 & 1 & 0 & 0 & 1 & 1 & 1\end{array}$

$\begin{array}{lllllllll}0 & 0 & 0 & 1 & 1 & 0 & 1 & 1 & 1\end{array}$

$\begin{array}{lllllllll}0 & 0 & 0 & 2 & 1 & 0 & 1 & 1 & 1\end{array}$

$\begin{array}{lllllllll}0 & 0 & 0 & 1 & 1 & 0 & ? & 1 & 1\end{array}$

$\begin{array}{lllllllll}0 & 0 & 0 & 1 & 1 & 0 & \text { ? } & 1 & 1\end{array}$

$\begin{array}{lllllllll}0 & 0 & 0 & 0 & 1 & \text { ? } & \text { ? } & 2 & 2\end{array}$

$\begin{array}{lllllllll}0 & 0 & 0 & 1 & 1 & \text { ? } & \text { ? } & 1 & \text { ? }\end{array}$

$\begin{array}{lllllllll}0 & 0 & 0 & 1 & 0 & 0 & ? & 1 & 1\end{array}$

$\begin{array}{lllllllll}0 & 0 & 0 & 1 & 0 & 0 & 1 & 1 & 1\end{array}$

$\begin{array}{lllllllll}0 & 0 & 0 & 2 & 0 & 0 & 1 & 1 & 2\end{array}$

$\begin{array}{lllllllll}0 & 0 & 0 & 1 & 0 & 0 & ? & 1 & 1\end{array}$

$\begin{array}{lllllllll}0 & 1 & 0 & 0 & ? & ? & ? & 1 & 0\end{array}$ 


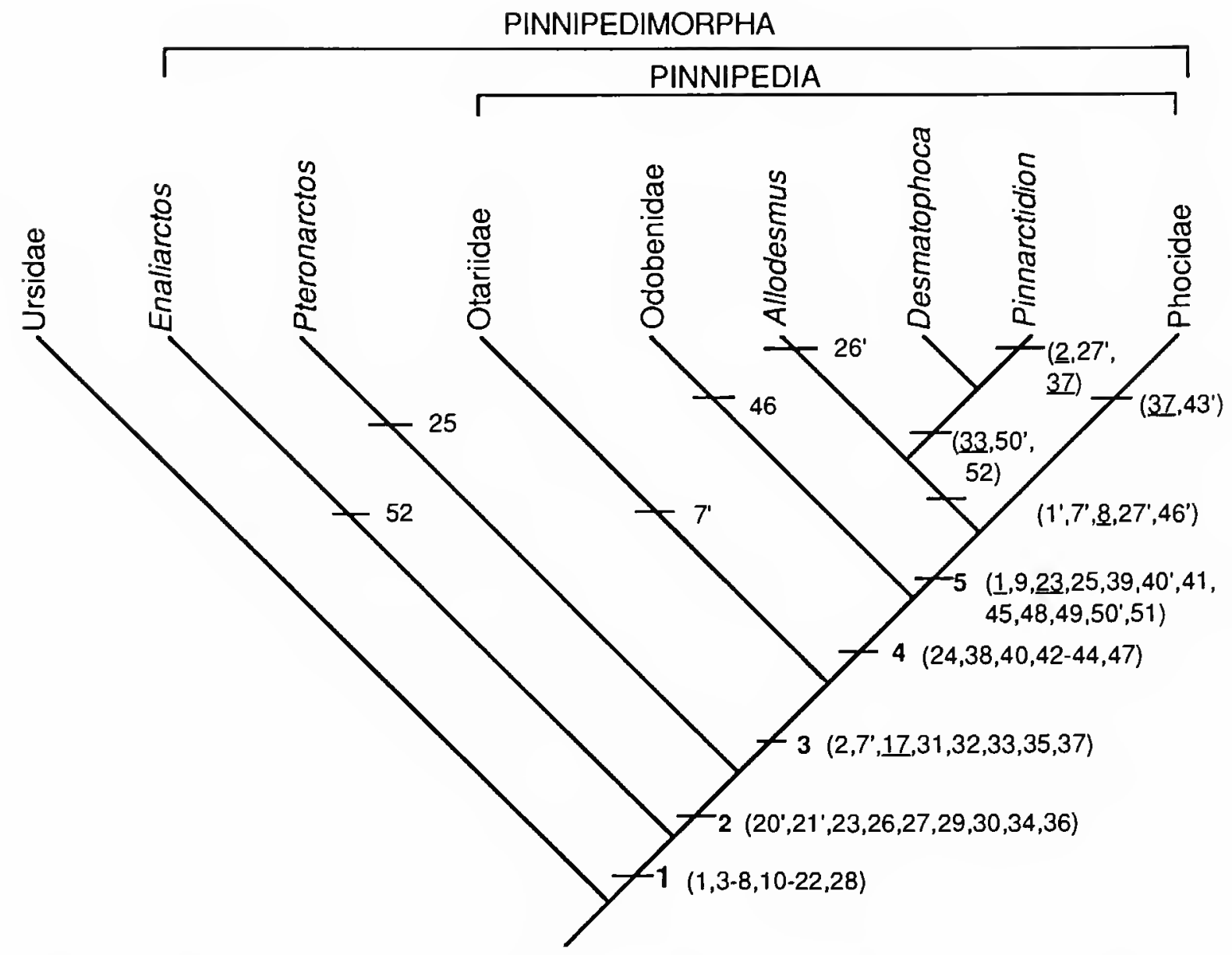

FIGURE 22.-Higher level relationships of Enaliarctos and "enaliarctids." Numbers refer to derived characters listed in Table 7 and discussed in text. Characters marked with a tick (') designate a multistate character. Postulated reversals to ancestral character states are underlined.

larger than in terrestrial camivorans (Wyss, 1987, table 1).

17. Pseudosylvian sulcus strongly developed. As described by Mitchell and Tedford (1973:237) in Enaliarctos mealsi the pseudosylvian (= sylvian) fossa is enlarged to a broad and deep crease down the side of the brain. Judging from the skull and endocranial cast of Cephalogale figured by de Beaumont (1965) the pseudosylvain sulcus does not appear to be strongly developed. According to Barnes (1989, fig. 9) Pteronarctos can be distinguished from Enaliarctos by its shallower pseudosylvian sulcus. Comparisons with additional specimens of Pteronarctos from the Emlong collection (Berta, in prep.) indicate that this is not the case. The presence of a strongly developed sulcus is recognized here as having evolved in pinnipedimorphs ancestrally and having subsequently been lost in pinnipeds.

19. $M^{1-2}$ small relative to premolars. The primitive pinniped dentition as exemplified by Enaliarctos is characterized by having $\mathrm{M}^{1-2}$ reduced relative to the premolars. As commented by Mitchell and Tedford (1973:251), "the degree of reduction of the upper molars in Enaliarctos compared with the premolars is greater than that of any known early arctoid." In all later pinnipeds the molars and premolars are subequal.

20. $M_{1}$ entoconid reduced-absent. An entoconid is present in primitive ursids. This cusp is reduced to a crest in Enaliarctos as noted by Mitchell and Tedford (1973) and suppressed in all later pinnipeds.

21. $M_{1}$ hypoconid reduced-absent. According to Mitchell and Tedford (1973) Enaliarctos can be distinguished from Cephalogale in having the hypoconid centrally positioned and separated from the trigonid by a broad groove. This cusp is suppressed in all later pinnipeds.

22. $M_{3}$ absent. Among primitive ursids, Amphicynodon, Pachycynodon, Allocyon, and Cephalogale, $\mathrm{M}_{3}$ is present. This tooth is absent in Enaliarctos and later pinnipeds.

28. $M^{1-2}$ cingulum reduced-absent. In the primitive condition, seen in Cephalogale and amphicyonids, an enlarged cingulum encircles the upper molars. This cingulum is reduced or absent in Enaliarctos and all later pinnipeds (Mitchell and Tedford, 1973).

The polarity of five other features, although unknown in Enaliarctos, have been assigned a most parsimonious distribution at this node. I treat three of these features, enlarged basal whorl of scala tympani (SYNAPOMORPHY 11), middle ear cavity and external auditory meatus presumably lined with distensible cavernous tissue (SYNA POMORPHY 16), and deciduous dentition reduced (SYNA POMORPHY 18), as apomorphies of the Pinnipedia clade, the minimum level at which observation confirms their distribution. Two additional features, maxilla makes a significant contribution to the orbital wall (SYNAPOMORPHY 3), and lacrimal fuses early to maxilla, greatly reduced or absent; does not contact jugal (SYNAPOMORPHY 6), are assigned as apomorphies at the level of the Unnamed Clade that includes Pteronarctos and all other pinnipeds. One additional character listed by Wyss (1987) as a potential pinniped synapomorphy 
(large cochlear aqueduct) requires further comparative study and measurement before it can be definitively assigned at this or any other level (Wyss, pers. comm.).

In addition to cranial and dental features the pinnipedimorphs are distinguished by a large number of synapomorphies of the postcranial skeleton reviewed elsewhere (Berta et al., 1989; Berta and Ray, 1990). Derived features of the forelimb include short, robust humerus with strongly developed deltopectoral crest and enlarged tuberosities; elongation of digit I in the manus and digits I and V in the pes; loss of supracondylar foramen on humerus ( a reversal in phocines). Shared derived features of the hindlimb include short ilium; extremely short anteroposteriorly flattened femur and medially inclined condyles; large, broadly developed greater trochanter on the femur and conical patella. In the axial skeleton, pinnipedimorphs share with all arctoids except ursids possession of an alar notch rather than a foramen on the atlas.

The next more restrictive clade is an unnamed group that includes the fossil taxon Pteronarctos and all other pinnipeds and is defined by nine cranial characters (Figure 22, node 2; Table 7). Because relationships among more inclusive pinniped clades were not the principal focus of this study, descriptions of characters as were provided in the preceding section for diagnosis of Pinnipedimorpha are not detailed here. Pteronarctos and all other pinnipeds are characterized dentally by a reduction in the number of roots on the upper molars (SYNAPOMORPHY 27). The upper molars of Enaliarctos and ursids have three separate roots. This number is reduced to two in Pteronarctos and phocids and one in all other pinnipeds.

The Pinnipedia clade is defined by 8 cranial characters (Figure 22, node 3). The fossa muscularis (SYNAPOMORPHY 32), prominent in Pteronarctos, Enaliarctos, and ursids, is absent in members of this group. This character and its proposed transformation warrant a few additional comments. As defined by Davis (1964:49) immediately behind the lacrimal fossa is a shallow pit, the fossa muscularis, in which the inferior oblique muscle of the eye arises; the thin floor of this pit is usually broken through on dry skulls, and then resembles a foramen. This fossa in Ursus is relatively enormous, as large as the lacrimal fossa. Examination of the skull of Cephalogale minor (Vienna Natural History Museum, Vienna A4445) reveals the presence of a slight depression behind the lacrimal fossa delimited by a ventrally floored ridge. A possible interpretation is that the condition in Cephalogale might be an intermediate stage in development of the deep, posteriorly positioned fossa seen in Enaliarctos and Pteronarctos. Following this transformation sequence, other pinnipeds are hypothesized to have lost this fossa.

As noted by Wyss (1987:16) another pinniped synapomorphy is "the presence of of an unossified space (often termed orbital vacuity) in the ventral wall near the juncture of the frontal, maxilla, and palatine bones...associated with the pinniped configuration of the maxilla" (SYNAPOMORPHY 33).
The derived pinniped palate lacks an embrasure pit on the palate between $\mathrm{P}^{4}$ and $\mathrm{M}^{1}$ to receive the crown of the lower carnassial, a conspicuous feature in Pteronarctos, Enaliarctos, and terrestrial carnivorans (SYNAPOMORPHY 34). This character together with a number of dental modifications including reduction or loss of $\mathrm{P}^{4}$ protocone (SYNAPOMORPHY 37), loss of $\mathrm{M}_{1}$ metaconid, entoconid, and hypoconid (SYNAPOMORPHIES $20,21,30$ ), and loss of $\mathrm{M}_{2}$ (SYNAPOMORPHY 31) indicate suppression of the carnassial function of these teeth, which is viewed as a trend toward homodonty exemplified by modern pinnipeds.

Synapomorphies of the pinniped postcranial skeleton (see also Berta et al., 1989; Berta and Ray, 1990) include, for the forelimb, flattening and posterior expansion of the olecranon process of the ulna and strong reduction of fifth intermediate phalanx of the manus. Pelvic girdle and hindlimb specializations include unfused pubic symphysis, loss of pit for ligament on femoral head, reduction or loss of trochanteric fossa on femur, and reduction of processus lateralis on the fibula. Both the manus and pes display hinge-like phalangeal articulations, flattened phalanges, and non-trochleated interphalangeal articulations. All pinnipeds (except living walruses) are characterized by having five lumbar vertebrae.

Monophyly of the Otariidae (= Otariinae Mitchell, 1968, 1975; Barnes, 1989) has traditionally been accepted (Repenning and Tedford, 1977; Berta and Demere, 1986; Barnes, 1989). This analysis identified only a single character reversal, the presence of large shelf-like supraorbital processes as uniting otariids (SYNAPOMORPHY 7). Relationships among the Otariidae are discussed further elsewhere (Berta and Demere, 1986; Berta, in prep.).

As proposed by Wyss (1987) odobenids and phocids and their fossil allies are sister taxa (Figure 22, node 4). Cranial features that support this clade include reduced contact between the premaxilla and nasals (SYNAPOMORPHY 38), and petrosal visible through posterior lacerate foramen (SYNAPOMORPHY 42). In addition, there are numerous derived features of the ear region that are more fully described by Wyss (1987). Among postcranial synapomorphies defined by Wyss in the previously mentioned paper are development of an at least incipiently caudally directed process on the astragalas, short calcaneal tuber, and enlarged baculum.

A more inclusive clade of pinnipeds including Pinnarctidion, Desmatophoca, Allodesmus, and Phocidae is united by 12 derived cranial features (Figure 22, node 5). These pinnipeds display a mortised contact between the squamosal and jugal (SYNAPOMORPHY 50), posteriorly wide palate (SYNAPOMORPHY 49), and nasals that terminate posterior to the frontal-maxillary contact (SYNAPOMORPHY 48). The lower jaw has a reduced coronoid process (SYNAPOMORPHY 45) and a mandibular flange developed below the ascending ramus (SYNAPOMORPHY 51). Relationships among these taxa are represented in Figure 22, in which Desmatophoca + Pinnarc- 
tidion + Allodesmus form an unnamed clade with Desmatophoca and Pinnarctidion linked as sister taxa. Pinnarctidion and Desmatophoca possess a squamosal-jugal articulation that is less modified than that displayed by Allodesmus and phocids in which this contact is dorsoventrally expanded (SYNAPOMORPHY 50). These taxa also lack development of large orbital vacuities (SYNAPOMORPHY 33) that are present in both Allodesmus and phocids. The Phocidae are monophyletic (for a recent systematic treatment see Wyss, 1988b).

The above analysis clearly shows that "enaliarctids" are paraphyletic. Enaliarctos* is the sister group of the remaining pinnipeds, and Pteronarctos and Pinnarctidion are placed in less inclusive clades. This is in contrast to the traditionally accepted phylogeny of "enaliarctids" as basal otariids involved only in the ancestry of some pinnipeds (sea lions, walruses, and their fossil allies (desmatophocids and allodesmids), but not true seals) (Barnes, 1979, 1989). According to Barnes (1989:19) the "Enaliarctinae are a horizontal group,... a grade rather than a clade." Recognition of the paraphyletic grade "Enaliarctinae" is an inappropriate systematic procedure. Such an approach is undesirable for many reasons, the most important of which is that it misrepresents the evolutionary history of pinnipeds. If one accepts the evidence reviewed here, then the phylogenetic arrangement of these taxa should reflect that knowledge. By grouping Pteronarctos and Pinnarctidion in the "Enaliarctinae" and arguing for "the taxonomic utility [of doing so], considering the still comparatively meager state of our knowledge of early otariid evolution," Barnes (1989:19) obscures what we do know about the interrelationships of these taxa.

\section{Conclusions}

Three new species of the archaic pinniped Enaliarctos* from the marine late Oligocene and early Miocene (Arikareean and Hemingfordian or early Barstovian correlatives) of coastal Oregon are described based on well-preserved crania and dentitions: $E$. barnesi (near Yaquina Formation-Nye Mudstone contact), E. emlongi (Nye Mudstone or Astoria Formation), and $E$. tedfordi (Yaquina Formation). An additional skull is referred to a previously described species, E. mitchelli (Nye Mudstone). These taxa differ principally in facial morphology and details of the dentition. Phylogenetic analysis of cranial and dental characters among these species and the genotype $E$. mealsi results in recognition of Enaliarctos as a metataxon, since monophyly of this taxon cannot be unambiguously determined. Relationships among Enaliarctos species are largely unresolved although there is some character evidence to support the common ancestry of $E$. tedfordi, E. emlongi, and $E$. mitchelli.

Phylogenetic analysis of 52 cranial and dental features among fossil taxa (Enaliarctos, Pteronarctos, Desmatophoca, Allodesmus, and Pinnarctidion) and extant pinniped families (Otariidae, Odobenidae, and Phocidae), supports the view that the "Enaliarctinae" (= "Enaliarctidae") is paraphyletic as well as the recognition that Enaliarctos* is the sister taxon of all other pinnipeds. Other taxa previously included in the "Enaliarctidae" (Pteronarctos and Pinnarctidion) show different relationships: $P$ teronarctos + all other pinnipeds form one monophyletic clade and internested within this clade are several other clades, one of which includes Pinnarctidion + Desmatophoca, Allodesmus, and the Phocidae. 


\section{Literature Cited}

Addicott, W.A.

1976. Neogene Molluscan Stages of Oregon and Washington. In A.E. Fritsche, H. Ter Best, Jr., and W.W. Womardt, editors, The Neogene Symposium, pages 95-116. San Francisco: Society of Economic Paleontologists and Mineralogists- [Annual Meeting, Pacific Section].

Armentrout, J.M.

1981. Correlation and Ages of Cenozoic Stratigraphic Units in Oregon and Washington. Geological Society of America Special Paper, 184: 137-148.

Armentrout, J.M., D.A. Hull, J.D. Beaulieu, and W.W. Rau, editors

1983. Correlation of Cenozoic Stratigraphic Units of Western Oregon and Washington. Oregon Department of Geology and Mineral Industries Oil and Gas Investigations, 7: 90 pages, 1 chart.

Barnes, L.G.

1979. Fossil Enaliarctine Pinnipeds (Mammalia: Otariidae) from Pyramid Hill, Kern County, California. Contributions in Science, Natural History Museum of Los Angeles County, 318:1-41, figures 1-22, tables 1-4.

1987a. An Early Miocene Pinniped of the Genus Desmatophoca (Mammalia: Otariidae) from Washington. Contributions in Science, Natural History Museum of Los Angeles County, 382:1-20, figures 1-9, 1 table.

1987b. Aetiocetus and Chonecetus, Primitive Oligocene Toothed Mysticetes and the Origin of Baleen Whales. [Abstract.] Joumal of Vertebrate Paleontology, 7 (Supplement to no. 3), 10A.

1989. A New Enaliarctine Pinniped from the Astoria Formation, Oregon, and a Classification of the Otariidae (Mammalia: Carnivora). Contributions in Science, Natural History Museum of Los Angeles County, 403:1-26, figures 1-9, tables 1-2.

Berggren, W., D.V. Kent, J.J. Flynn, and J.A. Van Couvering

1985. Cenozoic Geochronology. Geological Society of America Bulletin, 96:1407-1418.

Berta, A.

In prep. [New specimens of Pteronarctos (Pinnipediformes) from the Miocene of Oregon and Its relationship to the Otariidae.]

Berta, A., and T.A. Demere

1986. Callorhinus gilmorei n. sp., (Camivora: Otaridae) from the San Diego Formation (Blancan) and its Implications for Otariid Phylogeny. Transactions of the San Diego Society of Natural History, 21(7):111-126.

Berta, A., and C.E. Ray

1990. Skeletal Morphology and Locomotor Capabilities of the Archaic Pinniped, Enaliarctos mealsi. Journal of Vertebrate Paleontology, 10(2):141-157.

Berta, A., C.E. Ray, and A.R. Wyss

1989. Skeleton of the Oldest Known Pinniped, Enaliarctos mealsi. Science, 244:60-62.

Davis, D.D.

1964. The Giant Panda: A Morphological Study of Evolutionary Mechanism. Fieldiana: Zoology Memoirs, 3:1-334

De Beaumont, G.

1965. Contribution a l'etude du genre Cephalogale Jourdan (Camivora). Schweizerische Paläontologische Abhandlungen, 82:1-34, figures 1-28.

Domning, D.P., C.E. Ray, and M.C. McKenna

1986. Two New Oligocene Desmostylians and a Discussion of Tethytherian Systematics. Smithsonian Contributions to Paleobiology, 59: 56 pages.
Donoghue, M.J.

1985. A Critique of the Biological Species Concept and Recommendation for a Phylogenetic Alternative. Bryologist, 88:172-181.

Dubrovo, I.A.

1981. A New Subfamily of Fossil Seals (Pinnipedia Kamtschatarctinae subfam nov.) Proceedings of the Academy of Sciences of the USSR, 256:970-974 [in Russian].

1984. Miocene Seals from the Pacific Region. Paleontological Journal, 18(1):50-60 [in Russian].

Emlong, D.

1966. A New Archaic Cetacean from the Oligocene of Northwest Oregon. Bulletin of the Museum of Natural History, University of Oregon, $3: 1-51$.

Flynn, J.J., N.A. Neff, and R.H. Tedford

1988. Phylogeny of the Carnivora. In M.J. Benton, editor, The Phylogenetic Classification of the Tetrapods. Volume 2 (Mammals), pages 73-116. Oxford: Clarendon Press.

Gauthier, J.A.

1986. Saurischian Monophyly and the Origin of Birds. In K. Padian, editor, The Origin of Birds and the Evolution of Flight. Memoirs of the California Academy of Sciences, 8:1-55.

Gauthier, J.A., R. Estes, and K. de Quieroz

1988. A Phylogenetic Analysis of Lepidosauromorpha. In R. Estes and G. Pregill, editors, Phylogenetic Relationships of Lizard Families: Essays Commemorating Charles L. Camp, pages 15-98. Stanford Univ. Press.

Hunt, R.M., Jr.

1974a. The Auditory Bulla in Carnivora: An Anatomical Basis for Reappraisal of Carnivore Evolution. Journal of Morphology, 143(1):21-76.

1974b. Daphoenictis, a Cat-like Camivore (Mammalia, Amphicyonidae) from the Oligocene of North America. Journal of Paleontology, 48(5):1030-1047.

1977. Basicranial Anatomy of Cynelos Jourdan (Mammalia: Camivora), an Aquitanian Amphicyonid from the Allier Basin, France. Journal of Paleontology, 51(4):826-843.

King, J.E.

1983. Seals of the World. Second edition, 240 pages. Ithaca, New York: Comell University Press.

Maddison, W.P., M.J. Donoghue, and D.R. Maddison

1984. Outgroup Analysis and Parsimony. Systematic Zoology, 33:83-103.

McLaren, I.A.

1960. Are the Pinnipedia Biphyletic? Systematic Zoology, 9:18-28.

Merriam, C.W

1930. Allocyon, a New Canid Genus from the John Day Beds of Oregon. University of California Publications in Geological Sciences, 19:229-243, figures 1-5, plates 35, 36 .

Mitchell, E.D

1968. The Mio-Pliocene Pinniped Imagotaria. Journal of the Fisheries Research Board of Canada, 25:1843-1900.

1975. Parallelism and Convergence in the Evolution of Otariidae and Phocidae. Rapports et Procès-verbaux des Réunions, Conseil International pour l'Exploration de la Mer, 169:12-26.

Mitchell, E., and R.H. Tedford

1973. The Enaliarctinae: A New Group of Extinct Aquatic Carnivora and a Consideration of the Origin of the Otariidae. Bulletin of the American Museum of Natural History, 151(3):201-284, figures 1-27, tables 1-4. 
Mivart, G.

1885. Notes on the Pinnipedia. Proceedings of the Zoological Society of London, 1885:484-500.

Muizon, Ch. de

1982. Les relations phylogénétiques des Lutrinae (Mustelidae, Mammalia). Geobios, Mémoire Spécial, 6:259-277.

Munthe, J., and M.C. Coombs

1979. Miocene Dome-skulled Chalicotheres (Mammalia, Perissodactyla) from the Western United States: A Preliminary Discussion of a Bizarre Structure. Journal of Paleonlology, 53(1):77-91.

Repenning, C.A.

1976. Adaptive Evolution of Sea Lions and Walruses. Systematic Zoology, 25(4):375-390.

Repenning, C.A., and R.H. Tedford

1977. Otarioid Seals of the Neogene. Professional Papers of the United States Geological Survey, 992: 93 pages.

Sivertson, E.

1954. A Survey of the Eared Seals (Family Otariidae) with Remarks on the Antarctic Seals Collected by M/K "Norvegia" in 1928-1929. Det Norske Vedenskaps-Akademii Oslo, 36:1-76.

Snavely, P.D., Jr., N.S. MacLeod, H.C. Wagner, and D.L. Lander

1980. Geology of the West-central Part of the Oregon Coast Range. In Geologic Field Trips in Westem Oregon and Southwestem Washington, Bulletin of the Oregon Department of Geology and Mineral Industries, 101:39-58.
Snavely, P.D., Jr., N.S. MacLeod, H.C. Wagner, and W.W. Rau

1976. Geology of the Yaquina and Toledo Quadrangles, Oregon. United States Geological Survey Miscellaneous Investigations Series Map I-867, scale $1: 62,500$.

Snavely, P.D., Jr., W.W. Rau, and H.C. Wagner

1964. Miocene Stratigraphy of the Yaquina Bay Area, Newport, Oregon. Ore Bin, 26(8):133-151.

Swofford, D.L.

1989. Phylogenelic Analysis Using Parsimony (PAUP), Version 30. Champaign: Illinois Natural History Survey.

Tedford, R.H.

1976. Relationship of Pinnipeds to Other Carnivores (Mammalia). System atic Zoology, 25(4):363-374

Wozencraft, C.

1989. The Phylogeny of the Recent Carnivora. In John L. Gittleman, editor, Carnivore Behavior, Ecology, and Evolution, pages 495535. New York: Comell University Press.

Wyss, A.R

1987. The Walrus Auditory Region and Monophyly of Pinnipeds. American Museum Novitales, 2871:1-31, figures 1-7, tables 1-2.

1988a. Evidence from Flipper Structure for a Single Origin of Pinnipeds. Nature, 334:427-428.

1988b. On "Retrogression" in the Evolution of the Phocinae and Phylogenetic Affinities of the Monk Seals. American Museum Novitales, 2924: 38 pages. 





\section{REQUIREMENTS FOR SMITHSONIAN SERIES PUBLICATION}

Manuscripts intended for series publication receive substantive review (conducted by their originating Smithsonian museums or offices) and are submitted to the Smithsonian Institution Press with Form S1-36, which must show the approval of the appropriate authority designated by the sponsoring organizational unit. Requests for special treatment-use of color, foldouts, case-bound covers, etc.-require, on the same form, the added approval of the sponsoring authority.

Review of manuscripts and an by the Press for requirements of series format and style, completeness and clanty of copy, and arrangement of all material, as outlined below, will govern, within the judgment of the Press, acceptance or rejection of manuscripts and art.

Copy must be prepared on typewriter or word processor, double-spaced, on one side of standard white bond paper (not crasable), with 1\%" margins, submitted as ribbon copy (not carbon or xerox), in loose sheets (not stapled or bound), and accompanied by original art. Minimum acceptable length is 30 pages.

Front matter (preceding the text) should include: title page with only title and author and no other information, abstract page with author, title, series, etc., following the established format; table of contents with indents reflecting the hierarchy of heads in the paper; also, foreword and/or preface, if appropriate.

First page of text should carry the title and author at the top of the page; second page should have only the author's name and professional mailing address, to be used as an unnumbered footnote on the first page of printed text.

Center heads of whatever level should be typed with initial caps of major words, with extra space above and below the head, but no other preparation (such as all caps or underline, except for the underline necessary for generic and specific epithets). Run-in paragraph heads should use period/dashes or colons as necessary.

Tabulations within text (lists of data, often in parallel columns) can be typed on the text page where they occur, but they should not contain rules or numbered table captions.

Formal tables (numbered, with captions, boxheads, stubs, rules) should be submitted as carefully typed, double-spaced copy separate from the text; they will be typeset unless otherwise requested. If camera-copy use is anticipated, do not draw rules on manuscript copy.

Taxonomic keys in natural history papers should use the aligned-couplet form for zoology and may use the multi-level indent form for botany. If cross referencing is required between key and text, do not include page references within the key, but number the keyed-out taxa, using the same numbers with their corresponding heads in the text.

Synonymy in zoology must use the short form (taxon, author, year:page), with full reference at the end of the paper under "Literature Cited." For botany, the long form (taxon, author, abbreviated journal or book title, volume, page, year, with no reference in "Literature Cited") is optional.

Text-reference system (author, year:page used within the text, with full citation in "Literature Cited" at the end of the text) must be used in place of bibliographic footnotes in all Contributions Series and is strongly recommended in the Studies Series: "(Jones, 1910:122) $)^{n}$ or "... Jones (1910:122)." If bibliographic footnotes are required, use the short form (author, brief title, page) with the full citation in the bibliography.

Footnotes, when few in number, whether annotative or bibliographic, should be typed on separate sheets and inserted immediately after the text pages on which the references occur. Extensive notes must be gathered together and placed at the end of the text in a notes section.

Bibliography, depending upon use, is termed "Literature Cited," "References," or "Bibliography." Spell out titles of books, articles, joumals, and monographic series. For book and article titles use sentence-style capitalization according to the rules of the language employed (exception: capitalize all major words in English). For journal and series titles, capitalize the initial word and all subsequent words except articles, conjunctions, and prepositions. Transliterate languages that use a non-Roman alphabet according to the Library of Congress system. Underline (for italics) titles of journals and series and titles of books that are not part of a series. Use the parentheses/colon system for volume (number): pagination: "10(2):5-9." For alignment and arrangement of elements, follow the format of recent publications in the series for which the manuscript is intended. Guidelines for preparing bibliography may be secured from Series Section, SI Press.

Legends for illustrations must be submitted at the end of the manuscript, with as many legends typed, double-spaced, to a page as convenient.

Illustrations must be submitted as original art (not copies) accompanying, but separate from, the manuscript. Guidelines for preparing art may be secured from Series Section, SI Press. All types of illustrations (photographs, line drawings, maps, etc.) may be intermixed throughout the printed text. They should be termed Figures and should be numbered consecutively as they will appear in the monograph. If several illustrations are treated as components of a single composite figure, they should be designated by lowercase italic letters on the illustration; also, in the legend and in text references the italic letters (underlined in copy) should be used: "Figure 9b." Illustrations that are intended to follow the printed text may be termed Plates, and any components should be similarly lettered and referenced: "Plate $9 \mathrm{~b}$." Keys to any symbols within an illustration should appear on the art rather than in the legend.

Some points of style: Do not use periods after such abbreviations as "mm, ft, USNM, NNE." Spell out numbers "one" through "nine" in expository text, but use digits in all other cases if possible. Use of the metric system of measurement is preferable; where use of the English system is unavoidable, supply metric equivalents in parentheses. Use the decimal system for precise measurements and relationships, common fractions for approximations. Use day/month/year sequence for dates: "9 April 1976." For months in tabular listings or data sections, use three-letter abbreviations with no periods: "Jan, Mar, Jun," etc. Omit space between initials of a personal name: "J.B. Jones."

Arrange and paginate sequentially every sheet of manuscript in the following order: (1) title page, (2) abstract, (3) contents. (4) foreword and/or preface, (5) text, (6) appendixes, (7) notes section, (8) glossary, (9) bibliography, (10) legends, (11) tables. Index copy may be submitted at page proof stage, but plans for an index should be indicated when manuscript is submitted. 


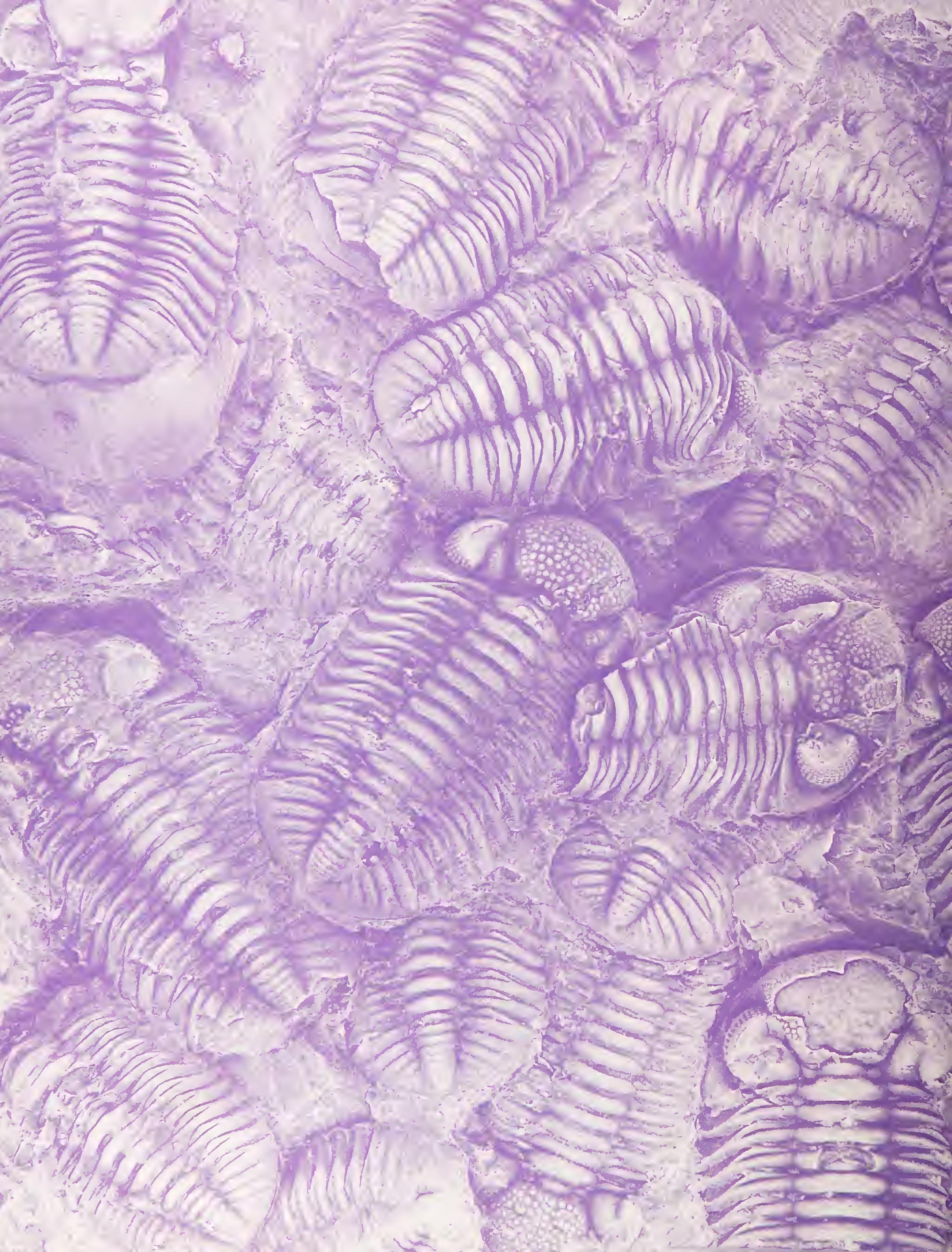

